\author{
UNIVERSIDADE DE SÃO PALILO \\ FACULDADE DE CIÊNCIAS FARMACÊUTICAS \\ Programa de Pós-Graduação em Ciência dos Alimentos \\ Área de Bromatologia
}

\title{
Caracterização e Controle de Qualidade de própolis proveniente de diversas regiões do Brasil
}

\author{
Adriana Hitomi Matsuda
}

Dissertação para a obtenção do grau de MESTRE

Orientador:

Profa. Dra. Ligia B. de Almeida Muradian

- São Paulo -

2006

18.418 


\section{DEDALUS - Acervo - CQ

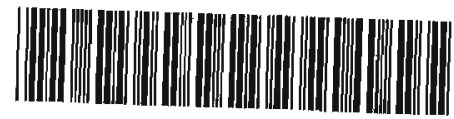 \\ 30100011560}

Ficha Catalográfica

Elaborada pela Divisão de Biblioteca e

Documentação do Conjunto das Químicas da USP.

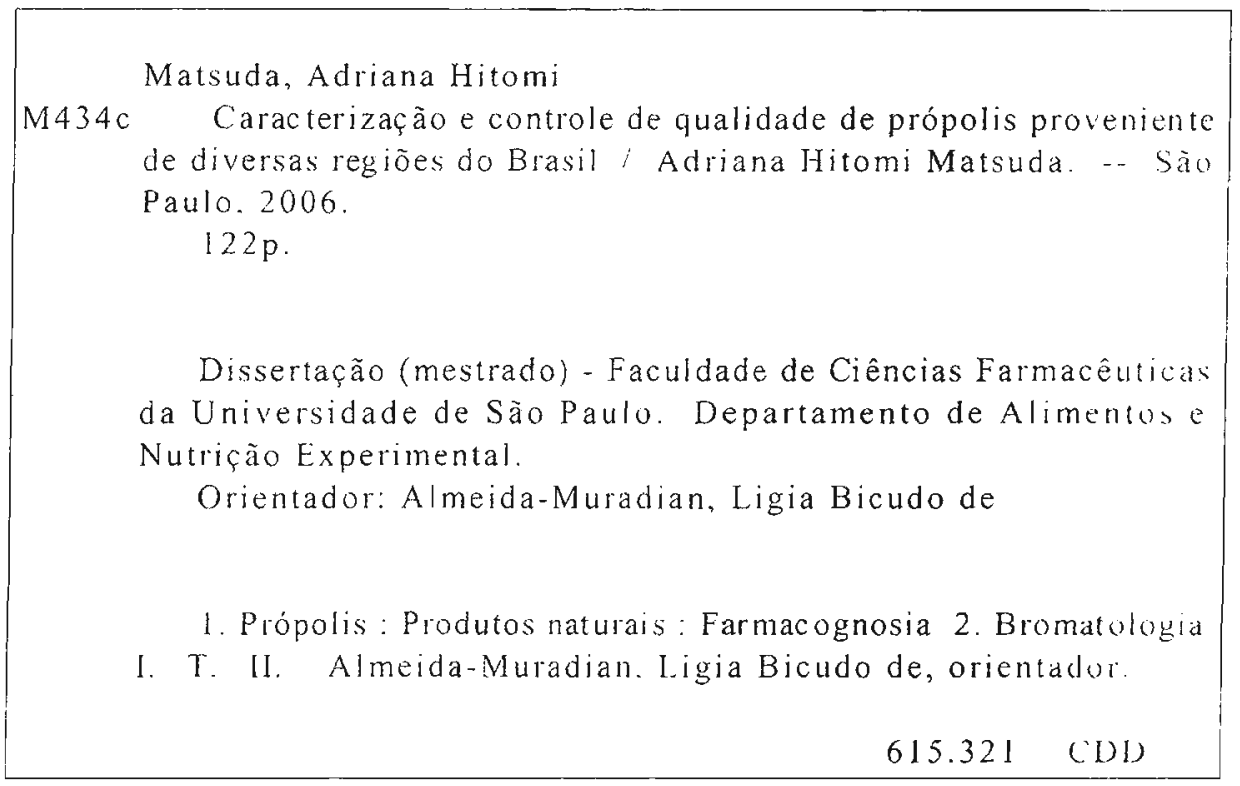


Adriana Hitomi Matsuda

Caracterizaçăo e Controle de Qualidade de própolis proveniente de diversas regiōes do Brasil

\author{
Comissão Julgadora \\ da \\ Dlssertaçăo para obtençăo do grau de Mestre
}

Profa. Dra. Ligia Bicudo de Almeida Muradian Orientador/presidente

Prof. Dra. Deborah Helena Markowicz Bastos

Prof. Dra. Elizabeth de Souza Nascimento

São Paulo, 23 de março de 2006. 


\section{CERTIFICADO DE DEFESA}

Certifico, para os devidos fins, que o(a) Sr(a). Adriana Hitomi Matsuda defendeu em sessão pública no dia 23 de março de 2006, a dissertação intitulada: "Caracterização e controle de qualidade de própolis proveniente de diversas regiões do Brasil", tendo sido aprovado(a), fazendo jus ao título de Mestre em Ciência dos Alimentos - Área de Bromatologia.

São Paulo, 23 de março de 2006.

$$
\text { Bunad Julo teriso }
$$

Profa. Dra. Bernadette Dora Gombossy de Melo Franco

Presidente da Comissão de Pós-Graduação FCF/USP 


\section{AGRADECIMENTOS}

A Prof. Dra. Ligia Bicudo de Almeida Muradian pela orientação, confiança, amizade e estímulo na realização deste trabalho.

À Faculdade de Ciências Farmacêuticas pela oportunidade oferecida para a realização deste trabalho.

Ao Laboratório CETAL pela utilização de suas instalações para as análises realizadas neste trabalho.

À Prof. Dra Ortrud Monika Barth Schatzmayr por toda ajuda na realização das análises polínica.

À Prof. Dra. Inar Castro pelo auxílio na análise estatística dos resultados.

À MSc. Izilda da Cruz de Araújo e Wagner pelo auxilio na realização das análises de cromatografia.

À Cláudia Passos pela orientação na realização da análise de antioxidante.

Aos amigos Adauto e Francisco pelo fornecimento de amostras de própolis de Minas Gerais.

Aos Apicultores que gentilmente forneceram amostras de própolis no decorrer do período de estudo.

À Adriana de Almeida Barreiros e Leila Aparecida Bonadio em todo o auxílio na pesquisa e correções das referências bibliográficas

Ás amigas Karla Cristina Lima da Silva Oliveira e Dra. Estuko pela amizade, carinho e companheirismo durante todo o trabalho.

Aos bolsistas-amigos pela amizade, contribuições e momentos de descontração.

A todos que de alguma forma contribuíram para o desenvolvimento deste trabalho. 
Dedico este trabalho aos meus pais, Norihito e Harko Matsuda, à minha irmã Andréa Harumi por estarem sempre ao meu lado me incentivando e me apoiado. 
Dedico este trabalho ao meu marido Claus Kazumi Muraoka pelo incentivo, amor e compreensão durante todo este trabalho. 


\section{SUMÁRIO}

LISTA DE ABREVIATURA …....................................... i

LISTA DE ILUSTRAÇÕES ............................................ ii

LISTA DE TABELAS ..................................................... iii

LISTA DE QUADROS iv

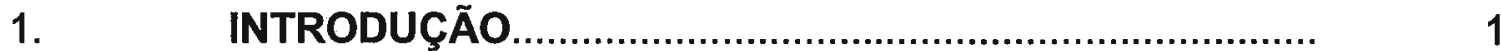

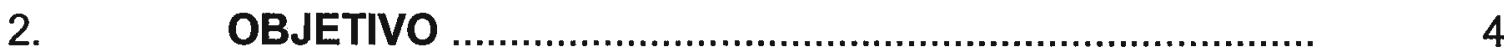

3. REVISÃO DA LITERATURA …........................................ 5

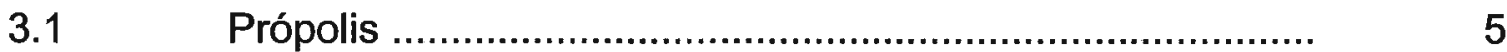

3.1.1 Origem Botânica ……........................................................ 10

3.1.2 Características físicas e sensoriais ..................................... 12

3.1.3 Composição química ............................................................ 13

3.1.4 Propriedades Biológicas ................................................. 19

3.1.5 Métodos Analíticos ........................................................... 21

3.1.6 Controle de Qualidade ..................................................... 24

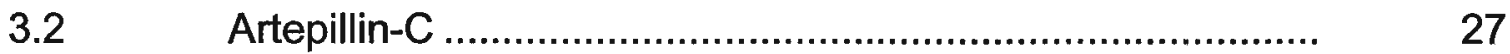

3.2.1 Metodologias para determinação de Artepillin-C em própolis .............................................................................. 28

4. MATERIAL E MÉTODOS ............................................. 30

4.1 Material 30

4.1.1 Coleta das amostras de própolis ........................................ 30

4.1.2 Padrões e Reagentes ..................................................... 33

4.1.3 Tratamento das amostras de própolis bruta ........................ 33

4.1.4 Preparo dos extratos etanólicos de própolis (EEP) .............. 34

4.1.5 Preparo dos extratos metanólicos de própolis (EMP) ......... 35

4.2 Métodos ................................................................. 37

4.2.1 Análises indicadas pela Legislação Brasileira para o padrão de identidade e qualidade da própolis .................... 37 
4.2.1.1 Determinação do teor de umidade ..................................... 37

4.2.1.2 Determinação de resíduo mineral fixo (Cinzas) ................... 37

4.2.1.3 Determinação do teor de cera ........................................... 38

4.2.1.4 Determinação da massa mecânica .................................... 38

4.2.1.5 Determinação de Substâncias solúveis em etanol .............. 39

4.2.1.6 Determinação do Índice de Oxidação ................................. $\quad 39$

4.2.1.7 Determinação Qualitativa dos Compostos Fenólicos por Espectrofotometria na região ultravioleta-visível (UVScanning)

4.2.1.8 Determinação Quantitativa dos Compostos Fenólicos presentes no extrato etanólico de própolis

4.2.1.8.1 Determinação de Flavonóides Totais com base em Quercetina

4.2.1.8.2 Determinação compostos fenólicos com base em ácido gálico

4.2.2 Determinação da atividade antioxidante

4.2.4 Determinação de Artepillin-C por Cromatografia Líquida de Alta Eficiência (CLAE)......................................................

4.2.4.1 Validação da Metodologia de Determinação de Artepillin-C 46

4.2.4.1.1 Linearidade ................................................................. 46

4.2.4.1.2 Limite de Detecção e Quantificação ................................... 47

4.2.4.1.3 Precisão ..................................................................... 48

4.2.4.1.4 Exatidão ......................................................................... 48

4.2.5 Determinação de Artepillin-C em amostras de própolis de 49 diversas regiões do Brasil

4.3 Análise Estatística........................................................... 50

4.5 Tratamento dos resíduos químicos .................................. 51

5. RESULTADOS E DISCUSSÃO ……............................. 52

5.1 Análises indicadas pela Legislação Brasileira para o padrão de identidade e qualidade da própolis ................... 52

5.1.1 Determinação do teor de umidade ..................................... 52 
5.1.2 Determinação de resíduo mineral fixo (Cinzas) ................. 56

5.1.3 Determinação do teor de cera .......................................... 59

5.1.4 Determinação da massa mecârica................................... 63

5.1.5 Determinação de substâncias solúveis em etanol .............. 66

5.1.6 Determinação do índice de oxidação ................................ 69

5.1.7 Determinação qualitativa dos compostos fenólicos por 72 espectrofotometria na região ultravioleta-visível (UVScanning)

5.1.8 Determinação de Flavonóides Totais com base em 76 quercetina dos extratos etanólicos de própolis

5.1.9 Determinação compostos fenólicos com base em ácido gálico.

5.2 Determinação da atividade antioxidante.

5.3 Análise polínica.

5.4 Validação da metodologia de determinação de Artepillin-C 90

5.4.1 Linearidade ................................................................ 91

5.4.2 Limite de detecção e quantificação .................................. 92

5.4.3 Precisão .................................................................. 93

Exatidão ............................................................. 94

5.4.5 Determinação de Artepillin-C por CLAE ............................ 95

6.

CONCLUSÕES

104

7. REFERÊNCIAS BIBLIOGRÁFICAS 


\section{LISTA DE ABREVIATURAS}
$A A=$ Porcentagem da atividade antioxidante
$\mathrm{BHT}=$ Hidroxibutiltolueno
CLAE = Cromatografia Líquida de Alta Eficiência
CV $=$ Coeficiente de variação
DP = Desvio Padrão
$\mathrm{DPPH}=1,1$-difenil-2picrilhidrazil
EEP $=$ Extrato etanólico de própolis
$\mathrm{EMP}=$ Extrato metanólico de própolis
IC = Intervalo de confiança
LD = Limite de detecção
$L Q=$ Limite de quantificação
$r^{2}=$ coeficiente de correlação 


\section{LISTA DE ILUSTRAÇÕES}

Página

Figura 1 Esquema de diferenciação dos componentes da colméia ............ 6

Figura 2 Glândulas presentes nas abelhas operárias ................................

Figura 3 Coleta de resina pelas abelhas para fabricação de própolis .........

Figura 4 Esquema de coleta de resinas e utilização da própolis pela abelha

Figura 5

Colméia

Figura 6 Coleta de resina das plantas e produção de própolis pelas abelhas

Figura 7

Coleta de resina das plantas pelas abelhas

Figura 8

Amostra de própolis

Figura 9 Estrutura química de flavonóide

Figura 10 Estruturas Estrutura química do Artepillin-C e do ácido cumárico.

Figura 11 Estruturas Estrutura química da Quercetina

Estrutura química do Artepillin-C

Figura 13

Coleta de própolis por raspagem

Figura 14 Mapa de distribuição dos pontos de coleta das amostras de própolis, obtidas no período de $2003-2005$

Figura 15 Diagrama esquemático do procedimento de obtenção do EEP ...

Figura 16 Diagrama esquemático do procedimento de obtenção do EMP ..

Figura 17 Gráfico da relação entre os teores de umidade de amostras de própolis em função das diversas regiões brasileiras

Figura 18 Gráfico da relação entre os teores de cinzas de amostras de própolis em função das diversas regiões brasileiras.

Figura 19 Gráfico da relação entre os teores de cera de amostras de própolis em função das diversas regiões brasileiras.

Figura 20 Gráfico da relação entre os teores de massa mecânica de amostras de própolis em função das diversas regiões brasileiras. 
Figura 21 Gráfico da relação entre os teores de substâncias solúveis de 68 amostras de própolis em função das diversas regiões brasileiras.

Figura 22 Gráfico da relação entre os índices de oxidação de amostras de própolis em função das diversas regiões brasileiras

Figura 23 Espectro de Absorção dos extratos etanólicos das amostras de 73 própolis bruta da região nordeste.

Figura 24 Espectros de Absorção dos extratos etanólicos das amostras de 74 própolis bruta da região sudeste.

Figura 25 Espectros de Absorção dos extratos etanólicos das amostras de própolis bruta da região sul

Figura 26 Espectros de Absorção dos extratos etanólicos das amostras de 76 própolis bruta diversas regiões centro oeste.

Figura 27

Curva de Calibração da Quercetina 77

Figura 28 Gráfico da relação entre teores de flavonóides totais de amostras de própolis em função das diversas regiões brasileira..

Figura 29 Gráfico da relação entre teores de fenólicos totais de amostras de própolis em função das diversas regiões brasileiras

Figura 30 Gráfico da relação entre a atividade antioxidante de amostras de própolis em função das diversas regiões brasileiras

Figura 31 Curva de Calibração do Artepillin-C 92

Figura 32 Perfil cromatográfico do padrão de Artepillin-C

Figura 34 Cromatograma característico de Artepillin-C da região centro100 oste.

Figura 35 Cromatograma característico de Artepillin-C da região Sudeste... 


\section{LISTA DE TABELAS}

Tabela 1 Localidades de amostragem de própolis bruta nas regiões

Nordeste, Norte, Sudeste e Sul do Brasil

Tabela 2 Condições cromatográficas para determinação de Artepillin-C .....

Tabela 3 Teor de umidade $(\% \mathrm{~m} / \mathrm{m})$ das amostras de própolis bruta de diferentes regiões do Brasil

Tabela 4 Resíduo mineral fixo $(\% \mathrm{~m} / \mathrm{m})$ de amostras de própolis bruta de diferentes regiões do Brasil

Tabela 5 Teor de Cera $(\% \mathrm{~m} / \mathrm{m})$ de amostras de própolis bruta de diferentes regiões do Brasil

Tabela 6 Massa Mecânica $(\% \mathrm{~m} / \mathrm{m})$ de amostras de própolis bruta de diferentes regiões do Brasil

Tabela 7 Teor de substâncias solúveis em etanol $(\% \mathrm{~m} / \mathrm{m})$ de amostras de própolis bruta de diferentes regiões do Brasil

Tabela 8 Índice de oxidação (s) das amostras de própolis bruta de diferentes regiões do Brasil

Tabela 9 Teor de flavonóides totais com base em quercetina dos extratos etanólico das amostras de própolis bruta

Tabela 10 Teor de fenólicos totais com base em ácido gálico dos extratos etanólico das amostras de própolis bruta.

Tabela 11 Atividade antioxidante dos extratos metanólico das amostras de própolis bruta

Tabela 12 Análise polínica das amostras de própolis após extração alcoólica, tratamento com $\mathrm{KOH}$ e acetólise.

Tabela 13 Desvio padrão relativo (coeficiente de variação percentual) das concentrações de Artepillin-C analisadas

Tabela 14 Precisão do método analítico para determinação de Artepillin-C em própolis bruta, expressa pelo desvio padrão e coeficiente de variação

Tabela 15 Taxa de recuperação do padrão de Artepillin-C adicionado na amostra de própolis

Tabela 16 Teor de Artepillin-C determinados por CLAE nas amostras de própolis bruta 


\section{LISTA DE QUADROS}

Página

Quadro 1 Principais flavonas e flavonóis encontrados em própolis bruta 16

Quadro 2 Compostos isolados da própolis bruta 18 


\title{
IDENTIFICATION AND QUALITY CONTROL OF PROPOLIS FROM SEVERAL REGIONS OF BRAZIL
}

\author{
Adriana Hitomi Matsuda
}

\begin{abstract}
Propolis is a resin of varied color and consistency collected by honeybee, Apis Mellifera, from several parts of the plant such as sprouts, flower buds and resinous exsudatos, being transported to the hive with the intent of defending and it has become really popular for its therapeutic properties, such as antimicrobial, anti inflammatory, healing anti-carcinogenic and anti-cancerigenous properties. Studies performed with the Brazilian propolis showed the presence of several phenolic compounds, as the most recent brings the identification of prenyl derivative of coumaric acid. Among them, the most studied one is 3,5-diprenyl-4-hydroxycinnamic acid (Artepillin-C), isolated from the propolis produced in areas which flora is rich in Baccharis species. Its quantification has become an important factor as indicator of Brazilian propolis quality. The aim of this study was to develop and validate a method to determine Artepillin- $C$, as well the identification and quantification of main parameters related to quality control of propolis forecasted in the current Brazilian regulation (moisture, ashes wax content, mechanic matter, content of solid soluble in ethanol, oxidation rate, total flavonoid and total phenolic). The polinic studies and antioxidant activity determination were also performed to complement this work. Propolis samples were obtained from beekeepers and warehouses summing up 33 samples from the Northeast, Southeast, Mid-West and South of Brazil from 2003 to 2005.

The propolis samples studied presented results which were almost all in accordance to the set limits by the Brazilian Agriculture Department. Most samples presented high antioxidant activity preventing oxidation from the coupled reaction of $\beta$ carotene to linoleic acid around $86,0 \%$.

The analysis method for Artepillin $\mathrm{C}$ addressed all the forecasted parameters for the validation of the chromatographic method (linearity, precision, a ccuracy, detection limit and quantification limit) as it can be recommended for the routine analysis in labs to control quality.

The statistics showed a strong relationship between the following parameters: ashes and mechanic matter; phenolic compounds and soluble in ethanol as well as phenolic compounds and antioxidant activity. It was also observed a variation in the figures for other studied parameters due to the origin of propolis samples.
\end{abstract}




\title{
CARACTERIZAÇÃO E CONTROLE DE QUALIDADE DE PRÓPOLIS PROVENIENTE DE DIVERSAS REGIÕES DO BRASIL
}

\author{
Adriana Hitomi Matsuda
}

\section{Resumo}

A própolis é uma resina de coloração e consistência variada coletada por abelhas da espécie Apis Mellifera de diversas partes da planta como brotos, botões florais e exsudados resinosos, sendo transportados para a colméia com a finalidade de defesa e vem se destacando p or suas a tividades terapêuticas, como a tividade antimicrobiana, antiinflamatória, cicatrizante, anticaríogênica e anticancerígena. Estudos realizados com a própolis brasileira mostraram a presença de muitos compostos fenólicos, sendo o mais recente, a identificação de derivados prenilados do ácido cumárico. Dentre estes, o mais estudado é o ácido 3,5-diprenil-4hidroxicinâmico (Artepillin-C), separada da própolis produzida em áreas cuja flora é rica em espécies de Baccharis. A sua quantificação tem se tornado um fator importante como indicador da qualidade da própolis brasileira. O objetivo deste estudo foi o desenvolvimento e a validação do método de determinação de ArtepillinC, assim como a caracterização e quantificação dos principais parâmetros relacionados ao controle de qualidade da própolis preconizada pela legislação brasileira vigente, foram realizadas análise de: umidade, cinzas, teor de cera, teor de massa mecânica, teor de sólidos solúveis em etanol, índice de oxidação, flavonóides totais e fenólicos totais. $O$ trabalho foi complementado com análise polínica e determinação da atividade antioxidante Amostras de própolis foram obtidas de apicultores e entrepostos totalizando 33 amostras procedentes das regióes Nordeste, Centro-Oeste, Sudeste e Sul do Brasil, no período de 2003 a 2005.

As amostras de própolis analisadas apresentaram resultados, na quase totalidade, de acordo com os limites estabelecidos pelo Ministério da Agricultura. A maioria das amostras apresentou alta atividade antioxidante inibindo a oxidação da reação acoplada de $\beta$-caroteno a ácido linoléico em torno de $86,0 \%$.

O método de análise de Artepillin $\mathrm{C}$ atendeu a todos os parâmetros preconizados para a validação do método cromatográfico (linearidade, precisão, exatidão, limite de detecção e limite de quantificação) podendo ser recomendado para análise de rotina em laboratórios de controle de qualidade.

A análise estatística mostrou uma forte correlação entre os seguintes parâmetros: cinzas e massa mecânica; compostos fenólicos e solúveis em etanol assim como os compostos fenólicos e atividade antioxidante. Também foi constatada uma variação nos valores dos outros parâmetros analisados em função da procedência das amostras de própolis. 


\section{INTRODUÇÃO}

Praticamente, todas as civilizações antigas, com as suas terapias milenares conheceram e utilizaram os produtos das abelhas como valiosos recursos na sua medicina. A história da medicina das civilizações chinesa, tibetana, egípcia e também a greco-romana é muito rica, todas contendo em seus escritos antigos, centenas de receitas, onde entram principalmente mel, própolis, larvas de abelhas e às vezes as próprias abelhas para curar ou prevenir enfermidades (GHISALBERTI, 1979).

A própolis é uma substância resinosa coletada pelas abelhas (espécie Apis mellifera) de diversas partes da planta como broto, botões florais e exsudatos resinosos. Sua composição química é bastante complexa e variada, estando intimamente relacionada com a característica da flora de cada região visitada pelas abelhas. De modo geral, a própolis contém $50-60 \%$ de resinas e bálsamos, $30-40 \%$ de ceras, $5-10 \%$ de óleos essenciais, $5 \%$ de grãos de pólen, além de pequenas quantidades de alumínio, cálcio, estrôncio, ferro, cobre, e também vitaminas: tiamina $\left(\mathrm{B}_{1}\right)$, riboflavina $\left(\mathrm{B}_{2}\right)$, piridoxina $\left(\mathrm{B}_{6}\right)$, ácido nicotínico $\left(\mathrm{B}_{3}\right)$, ácido ascórbico $(\mathrm{C})$, alfatocoferol (E), e o ácido pantotênico (B5) (GHISALBERTI, 1979). A própolis é conhecida, principalmente, por suas propriedades antimicrobiana, antioxidante, antiinflamatória, imunomodulatória, hipotensiva, cicatrizante, anestésica, anticancerigena, anti-HIV e anticariogênica (GHISALBERTI, 1979; BANKOVA; POPOV; MAREKOV, 1989; PARK et al.,1998a; 1998b; 2000; ISLA et al., 2001). A presença de compostos fenólicos, principalmente, os flavonóides, explica em parte a grande diversidade de propriedades biológicas relatadas na literatura (BANKOVA; POPOV; MAREKOV, 1983; PARK et al., 1995). 
Por tratar-se de uma categoria limitrofe situada entre alimento e medicamento, os produtos apícolas, especialmente, a própolis têm atraído a atenção da comunidade cientifica e profissionais da saúde para estudos que comprovem a eficácia destes na prevenção de várias enfermidades. Dentro deste contexto, os produtos apicolas tais como mel, pólen, geléia real e a própolis vêm despertando maior interesse dentro da área alimentícia (MATSUDA, 1994).

No Brasil, existe produção da própolis em toda a sua extensão, porém, sua qualidade varia de uma região para outra em função de diversos fatores ambientais. Assim, conhecem-se própolis provenientes das regiões Nordeste (Bahia), Norte (Amazonas), Centro-oeste (Mato Grosso, Goiás), Sudeste (São Paulo e Minas Gerais) e Sul (Paraná, Santa Catarina, Rio Grande do Sul), que apresentam diferentes compostos fenólicos na sua composição (MARCUCCl et al, 1998).

No Japão, a própolis brasileira está sendo extensivamente utilizada em alimentos e bebidas com a finalidade de manter ou melhorar a saúde humana (AGA et al., 1994).

Com a grande demanda da própolis brasileira no mercado internacional, tornou-se necessário um estudo mais detalhado em relação aos seus componentes, a influência de sua flora, condições ambientais, que a diferencie das demais própolis.

Estudos realizados com a própolis brasileira mostraram a presença de muitos compostos fenólicos, sendo o mais recente, a identificação de derivados prenilados do ácido cumárico. Dentre estes, o ácido 3,5-diprenil-4-hidroxicinâmico (Artepillin-C), separada da própolis produzida em áreas cuja flora é rica em espécies de Baccharis, é o mais estudado. A sua quantificação tem se tornado um fator importante como indicador da qualidade da própolis brasileira. Com exceção da 
região sudeste, poucos trabalhos foram desenvolvidos sobre a composição química e as propriedades biológicas da própolis oriunda de outras regiões brasileiras (AGA, et al., 1994; TOMÁS-BARBERÁN et al., 1993; BANKOVA et al., 1995; PARK; ALENCAR; AGUIAR, 2002; PARK et al., 2004).

Dado a importância desse composto fenólico, este trabalho tem como um dos objetivos o desenvolvimento e a validação do método de determinação de ArtepillinC, assim como a caracterização e quantificação dos principais parâmetros relacionados ao controle de qualidade da própolis, utilizando-se amostras originárias de diversas regiões brasileiras. 


\section{OBJETIVO}

Este trabalho tem como principais objetivos:

- Realizar as análises indicadas pela Legislação Brasileira para o padrão de identidade e qualidade (PIQ) da própolis bruta:

- Umidade;

- Cera;

- Cinzas;

- Massa mecânica;

- Substâncias solúveis em etanol;

- Índice de oxidação;

- Determinação qualitativa dos compostos fenólicos das amostras de própolis;

- Determinação quantitativa dos compostos fenólicos presentes no extrato etanólico de própolis.

- Atividade antioxidante das amostras de própolis;

- Análise polínica qualitativa das amostras de própolis;

- Validar a metodologia analítica para a determinação de Artepillin-C (ácido 3,5-diprenil-4-hidroxicinâmico) em própolis;

- Aplicar o método analítico validado para quantificar o Artepillin-C em própolis de diversas regiões do Brasil;

- Realizar análise estatística dos resultados obtidos. 


\section{REVISÃO DA LITERATURA}

\section{1 - Própolis}

O nome própolis é derivado do grego pro (em defesa) e polis (cidade), o que quer dizer, em defesa da cidade ou da colméia (GHISALBERTI, 1979).Trata-se de uma substância resinosa coletada, transformada e usada pelas abelhas para selar frestas em suas colméias, paredes internas e proteger a entrada contra os intrusos. As abelhas usam esta substância para se protegerem de insetos e microrganismos, empregando-a para fechar frestas e cavidades e no preparo de locais assépticos para a postura da abelha rainha. A própolis é também utilizada para embalsamar insetos invasores, evitando dessa forma a decomposição desses organismos que acarretariam no crescimento de microrganismos prejudiciais à colméia (BANKOVA; CASTRO; MARCUCCI, 2000; MARCUCCI, 1996).

Os primeiros estudos sobre a origem da própolis datam do início do século $X X$, com os trabalhos de Helfelberg (1908) que mostrou que as abelhas coletam resinas de ramos, follhas, botões de bétula e plantas contendo bálsamo e de Joubert (1927) que comprovou a origem vegetal da própolis de diversas variedades de plantas.

As abelhas encontradas no Brasil são geneticamente distintas das abelhas encontradas na Europa e na América do Norte. No Brasil houve uma extensiva hibridização entre as abelhas européias (Apis mellifera e Apis mellifera lingustica) com as abelhas africanas (Apis mellifera scutellata). Atualmente, as abelhas Apis mellífera no Brasil são chamadas de africanizadas (NEGRI et al., 1998).

A colméia pode ser vista como uma pequena cidade que possui organização 
social definida, onde seus habitantes possuem tarefas e atribuições específicas, e não são vistos como seres isolados. É composta por uma rainha, vários machos ou zangões e pelas operárias. A rainha tem função reprodutiva, chega a pôr 2000 ovos por dia e é fecundada pelo macho; este se alimenta de mel preparado pelas operárias, que estão em maior número na colméia e são responsáveis pela produção de mel, geléia real e própolis. As operárias defendem a colméia contra invasões, mantêm a limpeza e fabricam os favos (DONADIEU, 1980; WINTSON, 1987). A origem dos três componentes (rainha, zangão e operária) se define quando da postura dos ovos pela rainha, os quais podem ser fecundados ou não. No primeiro caso (ovo fertilizado), dão origem às rainhas e operárias, as quais irão diferenciar-se pela intensidade e qualidade da alimentação, e no segundo caso (ovo não fertilizado), dão origem aos zangões ou machos (Figura 1).

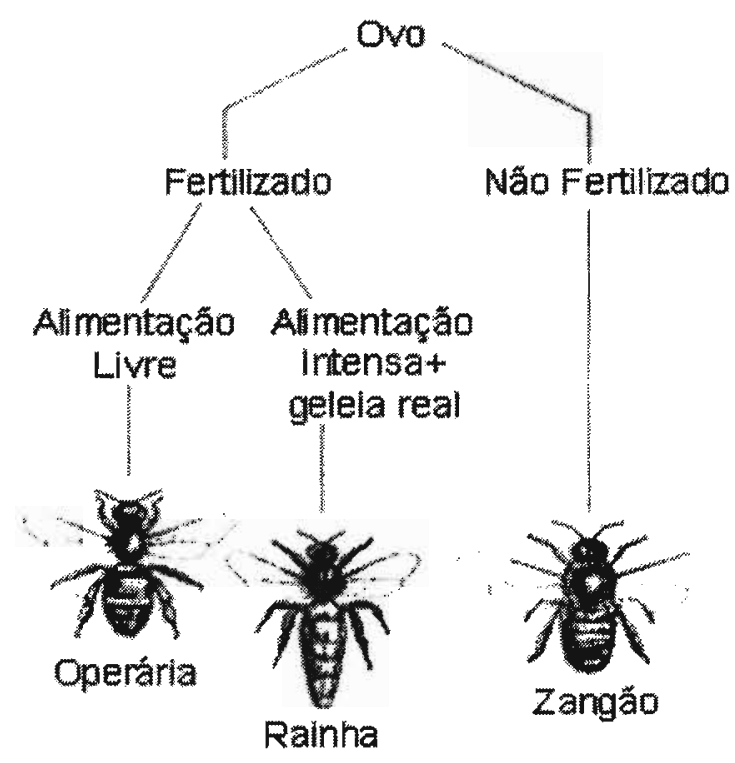

Figura 1 - Esquema de diferenciação dos indivíduos da colméia (WINTSON, 1987). 
Anatomicamente as operárias possuem glândulas com atividades específicas como produção de substâncias de alarme (mandibular), secreções de cera para a construção de favos (glândulas de cera), secreção de substâncias que atraem outras operárias para a realização de atividades específicas (glândulas de Nasanov), fornecimento de alimento para a cria, modificação do material recolhido dos vegetais pela adição de secreções próprias para a fabricação da própolis (glândulas hipofaríngeas, salivares e mandibulares) (FREE, 1980; WINTSON, 1987) (Figura 2).

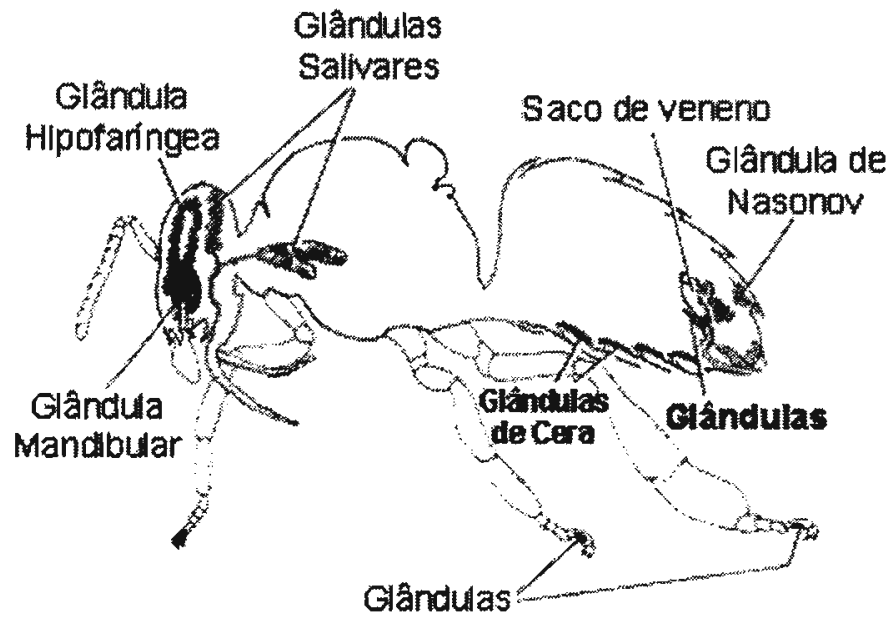

Figura 2 - Glândulas presentes nas abelhas operárias (WINTSON, 1987).

A própolis é produzidos á partir da coleta de material resinoso, gomoso ou balsâmico de botões de flores, sépalas e pétalas, folhas, caules e cascas de árvores. Primeiramente as operárias utilizam suas mandíbulas para cortar o material resinoso que é transferido às patas traseiras pelas patas medianas, para compactar e armazenar em espaços denominados corbículas (Figura 3). Esse material é levado para a colméia onde é retirado desses compartimentos por outra operária 
que retira a resina coletada com a ajuda de suas mandíbulas e a utiliza imediatamente, acrescentando secreções e enzimas (GHISALBERTI, 1979; GONZÁLES; ORZAES, 1997). O resumo esquemático da coleta da própolis pode ser visualizado na Figura 4.

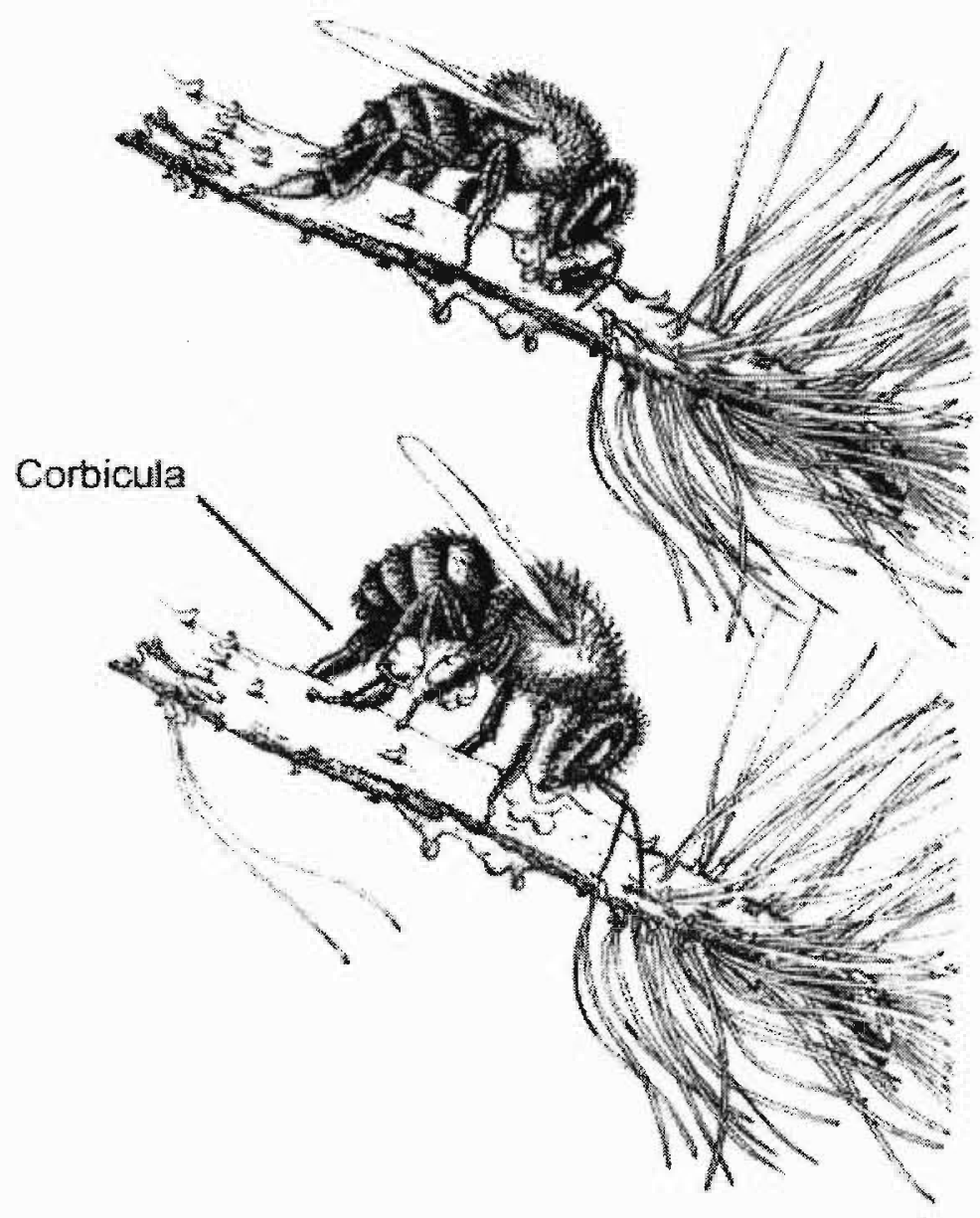

Figura 3 - Coleta de resina pelas abelhas para fabricação de própolis (WINTSON, 1987). 


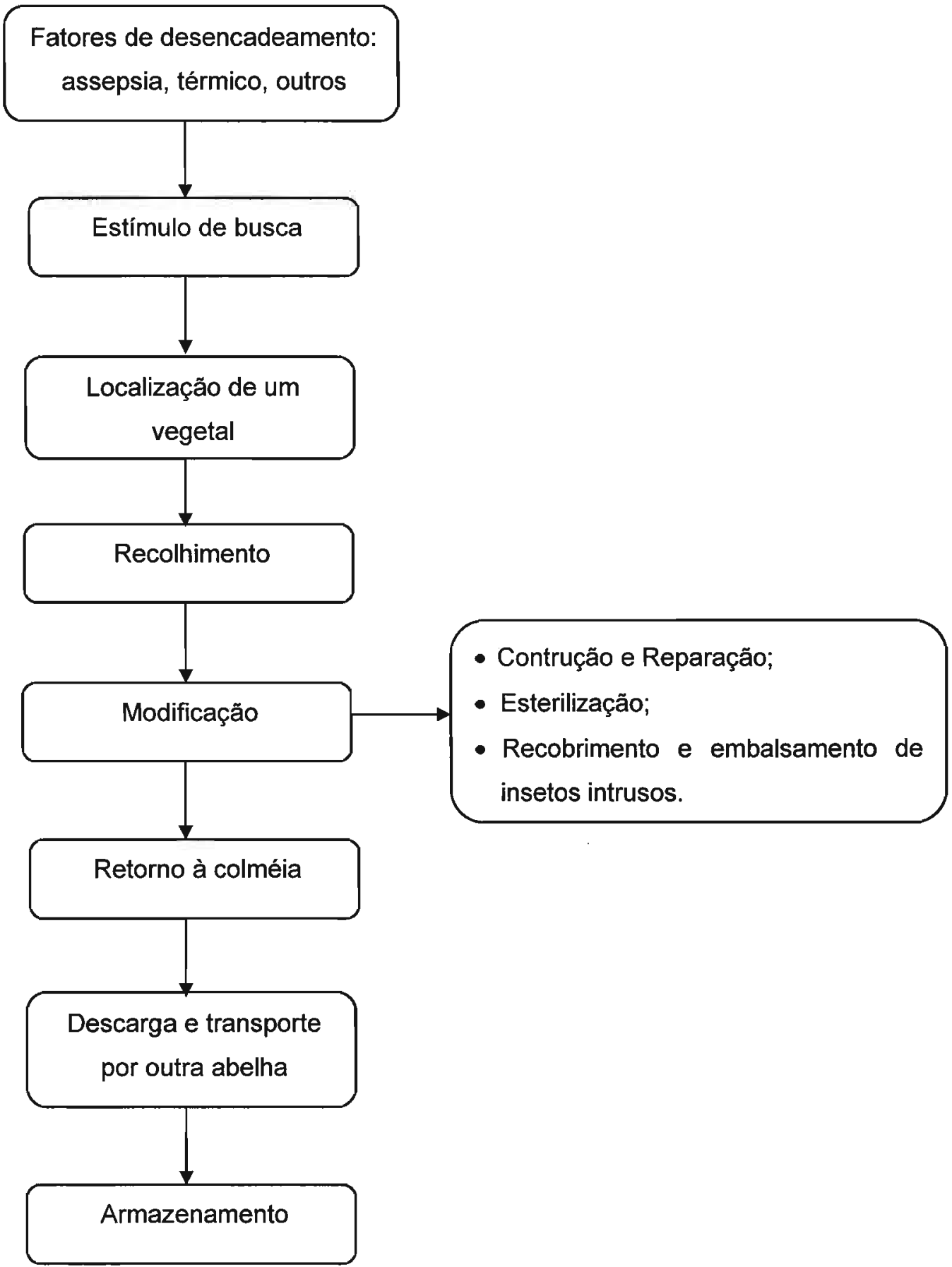

Figura 4 - Esquema de coleta de resinas e utilização da própolis pela abelha (DONADIEU, 1980). 
As abelhas usam a própolis em uma camada fina nas paredes internas de suas colméias ou outras cavidades nas quais elas habitam (Figura 5). É usado para fechar buracos e rachaduras, para consertar as colméias, para reforçar as beiradas finas, e para tornar a entrada da colméia resistente a intempéries. A própolis é também usada como uma substância para "embalsamar" para cobrir a carcaça de um invasor de colméia que as abelhas tenham matado, mas não possam carregar para fora da mesma, por exemplo: traças da cera (Galleria mellonella e Achroia grisella), mariposas (Acherontia átropos), e vespas (Vespa vulgaris, V. crabro) (GHISALBERTI, 1979).

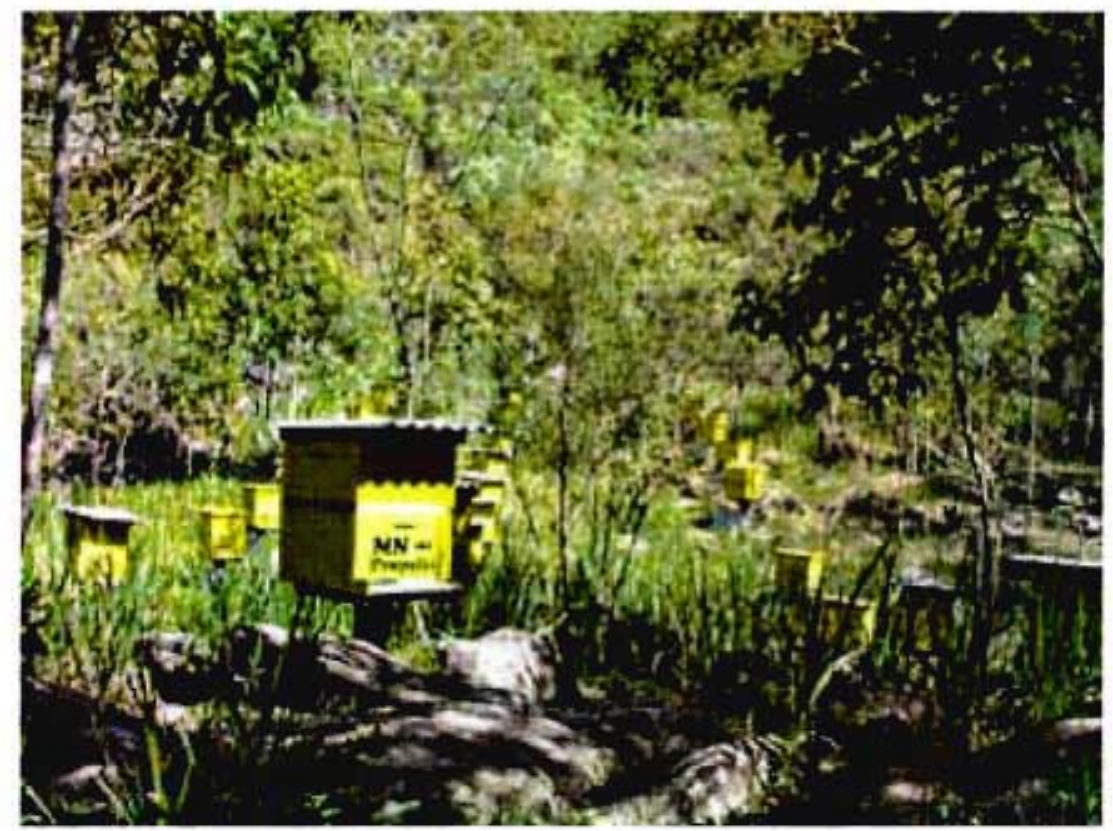

Figura 5 - Colméia (Fonte: Apiário MNH - Paraíbuna)

\subsection{1- Origem botânica}

Estudos realizados mostram que a própolis européia tem como principal fonte botânica às plantas do gênero Populus e apresenta, os flavonóides como constituintes majoritários (GARCIA-VIGUEIRA, 1992; BANKOVA; CASTRO; MARCUCCI, 2000a). 
Devido a grande diversidade da flora brasileira e a ausência de plantas do gênero Populus, a própolis brasileira apresenta composição química diferente da própolis européia e em conseqüência atividades biológicas distintas (MARCUCCl; BANKOVA, 1999).

As principais fontes vegetais da própolis brasileira são representadas pelas espécies: Baccharis dracunculifolia (alecrim do campo), Araucária angustifólia (pinheiro brasileiro) e o Eucalyptus citriodora (eucalipto). No entanto, algumas substâncias presentes na própolis brasileira não foram encontradas em extratos destas plantas, sugerindo a influência de outras espécies vegetais na formação e composição da própolis (BANKOVA et al., 1999).

A espécie Baccharis dracunculifolia é uma das mais procuradas pelas abelhas para a produção da própolis verde. Os derivados prenilados do ácido cumárico e do ácido 3,5-diprenil-4-hidroxicinâmico (Artepillin-C) estão presentes na própolis e nos extratos das folhas do vegetal (KUMAZAWA et al., 2003; MARCUCCl; BANKOVA, 1999). As Figuras 6 e 7 ilustram a coleta de resina das plantas e produção de própolis pelas abelhas. 

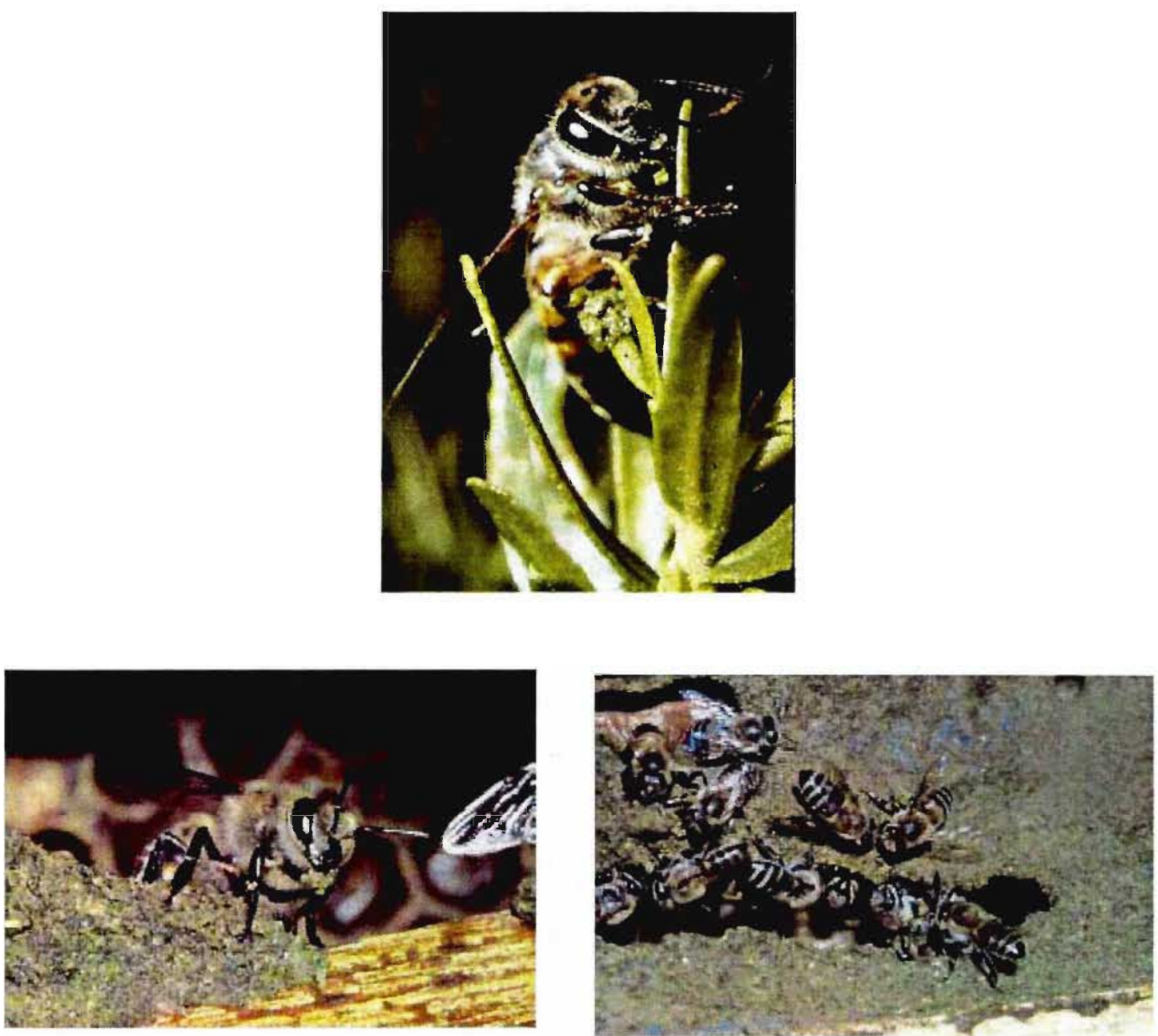

Figura 6 - Coleta de resina das plantas e produção de própolis pelas abelhas (KUMAZAWA et al., 2003).

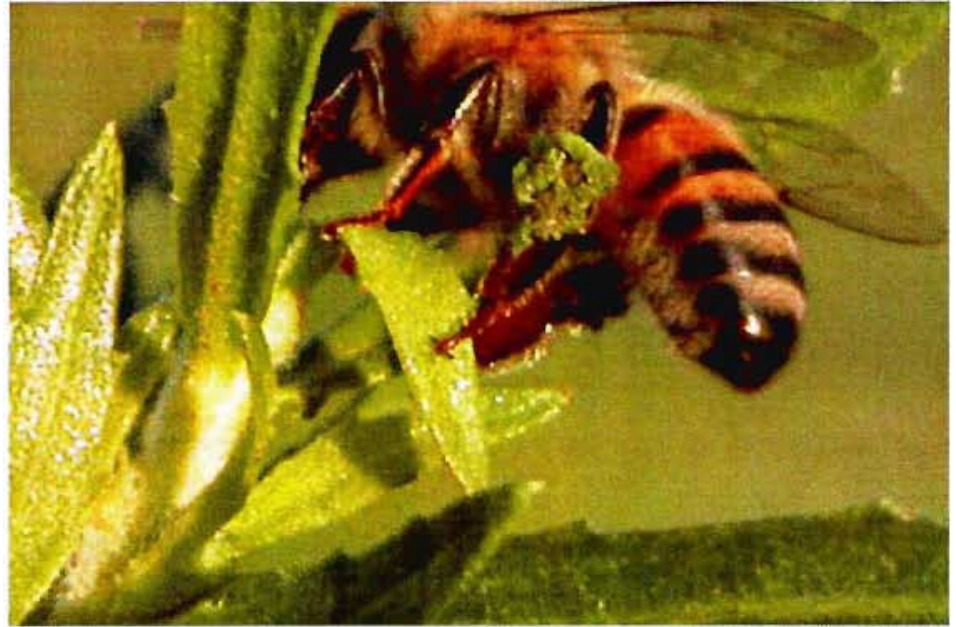

Figura 7- Coleta de resina das plantas pelas abelhas (Fonte: MN Própolis) 


\subsection{2- Características físicas e sensoriais}

A coloração da própolis, dependendo de sua procedência, varia de marrom escuro passando de uma tonalidade esverdeada até ao marrom avermelhado. Possui um odor característico que pode variar de uma amostra para outra, assim como existem amostras que não apresentam nenhum odor. O sabor é característico, variando de suave balsâmico a forte e picante, dependendo da origem botânica. $\mathrm{O}$ ponto de fusão varia entre $60-70^{\circ} \mathrm{C}$ e pode atingir, em alguns casos, até $100^{\circ} \mathrm{C}$ (MARCUCCI, 1996). A própolis é uma substância de consistência rígida à uma temperatura de aproximadamente $15^{\circ} \mathrm{C}$, tornando-se maleável a partir de $30^{\circ} \mathrm{C}$. Alguns solventes, tais como: éter, etanol, acetona, tolueno e tricloroetileno, permitem a solubilização de muitos constituintes. A parte insolúvel é constituída de matéria orgânica, tecidos vegetais, grãos de pólen e outros. Os compostos solúveis da própolis são constituídos por materiais cerosos, bálsamos, óleos essenciais e derivados fenólicos (BRASIL, 2001).

\subsection{3- Composição química}

A composição química da própolis é muito complexa e variada, estando intimamente relacionada com a ecologia vegetal de cada região visitada pelas abelhas. Tradicionalmente, considera-se que a própolis contém: $50-60 \%$ de resinas e bálsamos, $30-40 \%$ de ceras, $5-10 \%$ de óleos essenciais, $5 \%$ de grãos de pólen, além de pequenas quantidades de alumínio, cálcio, estrôncio, ferro, cobre, manganês e também de vitaminas $B_{1}, B_{2}, B_{6}, C$ e $E$ (GHISALBERTI, 1979). Atualmente, cerca de 160 componentes já foram identificados na própolis, principalmente compostos fenólicos. A maioria dos compostos fenólicos 
identificados pertence a dois grandes grupos: 1) fenilpropanóides (ácidos hidroxicinâmicos, flavonóides, ligninas, entre outros) e 2) terpenóides (mono, di e triterpenóides), cuja composição varia de acordo com a flora da região produtora (GREENAWAY; SAYSBROOK; WHATLEY, 1990; BANKOVA et al., 1992a), da variedade da abelha rainha e ainda, com a variação sazonal (BANKOVA et al., 1999). A figura 8 ilustra uma amostra de própolis bruta.

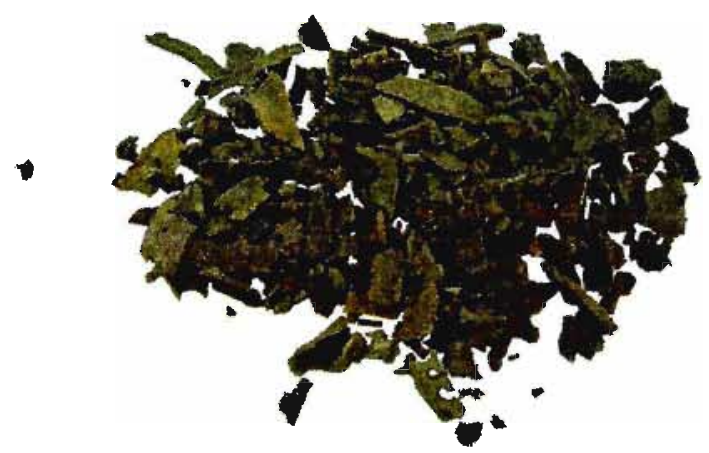

Figura 8 - Fotografia da própolis in natura (Fonte: Adriana Matsuda)

Estudos sobre a composição da própolis de regiões de clima temperado revelaram que a fração resinosa é constituída principalmente por compostos fenólicos, que constituem mais de $50 \%$ do seu peso total (WOISKY, 1996; KUJUMGIEV et al., 1999).

Os flavonóides constituem uma importante classe de polifenóis presentes em relativa abundância entre os metabólitos secundários de vegetais e, são encontrados particularmente nas folhas e pétalas. Representam um dos grupos fenólicos mais importantes e diversificados entre os produtos de origem vegetal. A maioria dos representantes dessa classe possui 15 átomos de carbono em seu núcleo fundamental que estão arranjados na configuração $C_{6}-C_{3}-C_{6}$, ou seja, com dois anéis aromáticos ligados por 3 átomos de carbono, que poderá ou não forma 
um terceiro anel (MARKHAM, 1982; ZUANAZZI, 1999) (Figura 9).

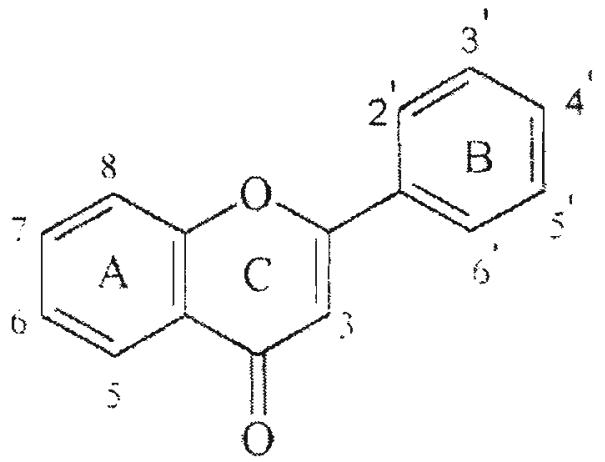

Figura 9 - Estrutura química básica do flavonóide (MARKHAM, 1992; ZUANAZZI, 1999)

Diversas funções são atribuídas aos flavonóides nas plantas. Entre elas pode-se citar: proteção dos vegetais contra a incidência de raios UV e visivel, contra insetos, fungos, virus e bactérias; atrair polinizadores, antioxidantes, controle dos hormônios vegetais e inibição de enzimas (ZUANAZZI, 1999).

Os flavonóides podem ser utilizados como marcadores taxonômicos devido, a sua abundância relativa em quase todo o reino vegetal, especificidade em algumas espécies, relativa facilidade de identificação, relativa estabilidade e acúmulo com menor influência do meio ambiente (ZUANAZZI, 1999).

A atividade bioquímica dos flavonóides e seus metabólitos depende da sua estrutura e orientação relativa das várias partes da molécula (COOK; SAMMAN, 1996).

As classes de flavonóides mais freqüentemente encontradas na própolis são representadas pelas flavonas, flavonóis, diidroflavonóis, flavanonas, chalconas e diidrochalconas (MARCUCCI, 1995; NAGAY; GRANCAI, 1996). As principais flavonas e flavonóis encontrados na própolis bruta estão descritos no Quadro 1. 
Quadro 1 - Principais flavonas e flavonóis encontrados em própolis bruta.

\begin{tabular}{|c|c|c|c|}
\hline \multicolumn{2}{|c|}{$\begin{array}{l}\mathbf{R}=\mathbf{H} \\
\text { Flavonas }\end{array}$} & \multicolumn{2}{|l|}{$\begin{array}{c}\mathrm{R}=\mathrm{OH} \\
\text { Flavonóis }\end{array}$} \\
\hline $\begin{array}{l}\text { Apigenina }\left(5,7,4^{\prime}-\mathrm{OH}\right) \\
\text { Crisina }(6,7-\mathrm{OH}) \\
\text { Tectocrisina }\left(5-\mathrm{OH}, 7-\mathrm{OCH}_{3}\right) \\
\text { Acacetina }\left(7-\mathrm{OH}, 4^{\prime}-\mathrm{OCH}_{3}\right)\end{array}$ & $\begin{array}{l}\text { GREENAWAY } \\
\text { et al., 1990). }\end{array}$ & $\begin{array}{l}\text { Canferol-3-metil éter } \\
\text { Canferol-7-metil éter } \\
\text { Canferol-7, 4'-dimetil éter } \\
\text { Galangina-3-metil éter } \\
\text { Fisetin (7,3',4'-OH) }\end{array}$ & $\begin{array}{l}\text { GREENAWAY et } \\
\text { al., 1990). }\end{array}$ \\
\hline $\begin{array}{l}\text { Pectolinarigenina } \\
\left(5,7-d i-O H, 6,4 \text { '-di- } \mathrm{OCH}_{3}\right)\end{array}$ & $\begin{array}{l}\text { VANHAELEN; } \\
\text { VANHAELEN- } \\
\text { FASTRÉ, } \\
\text { 1979) }\end{array}$ & $\begin{array}{l}\text { Betuletol }\left(5,7-\mathrm{OH}, 6,4^{\prime}-\mathrm{OCH}_{3}\right) \\
\text { Quercetina }\left(5,7,3^{\prime}, 4^{\prime}-\mathrm{OH}\right) \\
\text { Quercetina-3, 7-dimetil éter } \\
\text { Ramnazina }\left(5,4^{\prime}-\mathrm{OH}, 7,3^{\prime}-\mathrm{OCH}_{3}\right) \\
\text { Isoramnetina }\left(5,7,4^{\prime}-\mathrm{OH}, 3^{\prime}-\mathrm{OCH}_{3}\right) \\
\text { Ermanina }\left(5,7-\mathrm{OH}, 4^{\prime}-\mathrm{OCH}_{3}\right) \\
\text { Raminocitrina }\left(5,4^{\prime}-\mathrm{OH}, 7-\mathrm{OCH}_{3}\right) \\
\text { Izalpinina }\left(5-\mathrm{OH}, 7-\mathrm{OCH}_{3}\right) \\
\text { Galangina }(5,7-\mathrm{OH}) \\
\text { Canferol }\left(5,7,4^{\prime}-\mathrm{OH}\right) \\
\text { Canferida }\left(5,7-\mathrm{OH}, 4^{\prime}-\mathrm{OCH}_{3}\right)\end{array}$ & $\begin{array}{l}\text { VANHAELEN; } \\
\text { VANHAELEN- } \\
\text { FASTRÉ; 1979) }\end{array}$ \\
\hline $\begin{array}{l}\text { Pilloina } \\
\left.\text { (5,3-di-OH, 7,4'-di- } \mathrm{OCH}_{3}\right)\end{array}$ & $\begin{array}{l}\text { MACIEJEWICZ } \\
\text { et al., 2001) }\end{array}$ & 5-metoxi-3, 7-hidroxiflavona & $\begin{array}{l}\text { (PAPAY et al., } \\
\text { 1985) }\end{array}$ \\
\hline
\end{tabular}

Alguns compostos fenólicos utilizados para estabelecer a qualidade da própolis são: ácido cumárico, ácido ferúlico, galangina, quercetina canferol e, mais recentemente, o artepillin-C. A estrutura química do ácido cumárico, artepillin-C e da quercetina pode ser visualizadas nas figuras 10 e 11. 


\section{Artepillin-C}<smiles>CC(C)=CCc1cc(/C=C/C(=O)O)cc(CC=C(C)C)c1O</smiles>

\section{Ácido Cumárico}<smiles>O=C(O)/C=C/c1ccc(O)cc1</smiles>

Nome químico: ácido 3,5-diprenil-4-hidroxicinâmico e ácido p-cumárico

Figura 10 - Estrutura química do Artepillin-C e ácido cumárico (SHIMIZU et al, 2004)

\section{Quercetina}<smiles>C=C1C(O)=C(c2ccccc2)Oc2cc(O)cc(C)c21</smiles>

Nome químico: 2- (3,4-diidrofenil)-3,5,7, triidroxi-4H-1-benzopirano-4-ona; 3, 3', 5, 7pentaiidroxiflavona.

Figura 11 - Estrutura química da quercetina (MERCK index, 1996). 
Outros componentes, como derivados do benzáldeído, compostos heteroaromáticos (BANKOVA; POPOV; MAREKOV, 1982), compostos terpênicos (GREENAWAY; SAYSBROOK; 1990), minerais e aminoácidos (GONZÁLES; ORZALES, 1997), estão presentes em menores quantidades na própolis. Exemplos de compostos já isolados na própolis podem ser visualizados na Quadro 2.

Quadro 2 - Compostos isolados na própolis bruta.

\begin{tabular}{|c|c|}
\hline Estrutura básica & Composto \\
\hline Álcoois & $\begin{array}{l}\text { Álcool cinâmico, glicerol, hidroquinona, } \\
\text { isobutanol, álcool prenílico }\end{array}$ \\
\hline Aldeídos & 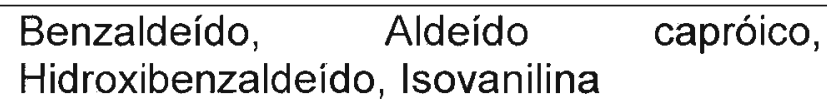 \\
\hline Ácidos alifáticos e ésteres alifáticos & $\begin{array}{l}\text { Ácido acético, ácido butírico, ácido } \\
\text { fumárico, ácido isobutírico. }\end{array}$ \\
\hline Aminoácidos & $\begin{array}{l}\text { Alanina, ácido glutâmico, glicina, histidina, } \\
\text { isoleucina, leucina, tirosina, cistina, } \\
\text { prolina, }\end{array}$ \\
\hline Ácidos aromáticos & $\begin{array}{l}\text { Ácido benzóico, ácido caféico, ácido } \\
\text { cumárico, ácido ferúlico, ácido gálico }\end{array}$ \\
\hline Ésteres aromáticos & $\begin{array}{l}\text { Acetato de benzila, benzoato de benzila, } \\
\text { cafeato de benzila }\end{array}$ \\
\hline Flavanonas & $\begin{array}{l}\text { Naringenina, alpinetina pinobansquina, } \\
\text { pinocembrina, pinostrombina }\end{array}$ \\
\hline Flavonas e flavonóis & $\begin{array}{l}\text { Acacetina, apigenina, crisina, galangina, } \\
\text { canferol, quercetina, ramnetina }\end{array}$ \\
\hline Ácidos graxos & $\begin{array}{l}\text { Ácido esteárico, ác. láurico, ac. linoléico, } \\
\text { ác. cerótico, ác. oléico, ác. Palmítico. }\end{array}$ \\
\hline Terpenóides & $\beta$-bisabolol, geraniol, farnesol \\
\hline Açúcares & Frutofuranose, sacarose, xilitol. \\
\hline Minerais e metais & $\mathrm{Mg}, \mathrm{Ca}, \mathrm{Zn}, \mathrm{Al}, \mathrm{Fe}, \mathrm{Mn}, \mathrm{Cd}, \mathrm{Pb}$ \\
\hline
\end{tabular}

Fonte: (MARCUCCl, 1995; WALKER \& CRANE, 1987). 
Além do perfil químico, outra forma de identificar a origem vegetal da própolis é através da análise microscópica de superfícies dos grãos de pólen que freqüentemente a contaminam, e que podem revelar a espécie vegetal de onde se origina. Além dos grãos de pólen, a própolis também é contaminada com fragmentos de folhas que são cortadas pelas abelhas durante a coleta dos exsudados vegetais. Estes fragmentos também podem ser considerados como importantes marcadores porque muitas espécies vegetais acumulam seus esxudados em glândulas de folhas. Assim tanto, os grãos de pólen quanto os fragmentos de folha são de grande valor sistemático na análise da origem botânica da própolis (VALCIC et al., 1999; WARAKOMSKA; MACIEJEWICZ, 1992; BARTH, 2004).

Estudos realizados com a própolis brasileira têm mostrado que ela contém principalmente derivados prenilados do ácido cumárico, sendo estes compostos isolados de diferentes espécies de Baccharis. Desta forma, tem se sugerido que o exsudatos de folhas de várias espécies de Baccharis que atraem abelhas em regiões tropicais possam ser uma das principais fontes para a própolis (MARCUCCI et al., 1998a).

\subsection{4- Propriedades biológicas}

A própolis contém uma variedade de compostos biologicamente ativos e suas propriedades são conhecidas há milhares de anos, sendo utilizada na medicina popular desde 300 a.C. Há relatos de sua utilização pelos persas, gregos, romanos e incas. Na Grécia era usada na forma de ungüentos e os egípcios a utilizavam para embalsamar cadáveres (WOISKY; GIESBRECHT; SALATINO, 1994).

A atividade biológica da própolis está diretamente relacionada com a 
presença de substâncias específicas e, dada a possibilidade de conter diferentes componentes de acordo com a região de coleta, é comum encontrar própolis com diferentes atividades biológicas: antimicrobiana, cicatrizante, anestésica, antiinflamatória (GHISALBERTI, 1979), anticariogênica (IKENO, K.; IKENO, T; MIYAZAWA, 1991), antitumoral (SCHELLER et al., 1977; FRENKEL et al., 1993), anticarcinogênica (GRUNDBERGER et al., 1998), antiviral (DEBIAGGI et al., 1990), anti-herpes (VYNOGRAD, N.; VYNOGRAD, I; SOSNOWSKI., 2000) e anti-HIV (ITO et al., 2001).

A atividade antibacteriana da própolis é atribuída à ação dos flavonóides, ácidos aromáticos e seus ésteres presentes na resina. O ácido cafeico demonstrou atividade contra Staphylococcus aureus e Pseudomonas vulgaris e o ácido ferúlico contra algumas bactérias Gram-positivas e Gram-negativa (GHISALBERTI, 1979). A galangina, pinocembrina e pinostrombina têm sido reconhecidos como os flavonóides de maior atividade antibactericida (PEPEJNJAK; JALSENJAK; MAYSINGER, 1985).

O mecanismo da atividade antimicrobiana é muito complexo e pode estar associado ao efeito sinérgico entre flavonóides, hidroxiácidos e sesquiterpenos (KEDZIA; IWASZKIWCZ, 1990; KROL et al., 1993; SCHELLER et al., 1977a). A estocagem da própolis por 3 a 4 anos, à temperatura de $0^{\circ} \mathrm{C}$ e $4^{\circ} \mathrm{C}$, ou a temperatura ambiente, não reduz sua atividade antimicrobiana (BONHEVI et al., 1994).

A própolis apresenta um importante potencial antifúngico contra espécies do gênero Trichophyton e Mycrosporum, na presença de proprilenoglicol. Foram comprovados também, efeitos sinérgicos do extrato etanólico de própolis associado a drogas antifúngicas contra Candida albicans, também foi comprovada 
(MARCUCCI, 1996).

O artepillin-C (ácido 3,5-diprenil-4-hidroxinârnico), composto isolado da própolis exibe efeito citotóxico contra células malignas tanto "in vivo" quanto "in vitro" (MATSUNO, 1997). O artepillin-C causa citoxicidade em tumores sólidos e em células leucêmicas. A apoptose, mitose abortiva, também foram confirmada através dos estudos histológicos (KIMOTO et al., 1998).

De acordo com estudos realizados com a própolis, as substâncias que possuem maior atividade anticarcinogênica são os derivados do ácido cafêico, flavonóides, ácidos 2,2-dimetil-8-prenil-cromona-6-propanóico, artepillin-C e 17hidroxicleroda-3-(13Z)-dien-15-oic (BANSKOTA et al., 1998).

O estudo da atividade biológica requer o conhecimento prévio da composição da própolis, pois é ela que determina a natureza dos efeitos biológicos. Deve-se levar em consideração que algumas própolis podem apresentar a maior parte de suas atividades simultaneamente, enquanto que outras podem apresentar uma atividade biológica quase nula. Por esta razão, não se pode generalizar as propriedades biológicas para cada tipo de própolis (PALMA; MALASPINA, 1999).

\subsection{5- Métodos analíticos}

Os métodos analíticos quali e quantitativo propostos para determinação dos flavonóides encontrados na própolis utilizam diversas técnicas como a cromatografia em papel, cromatografia em camada delgada, espectrofotometria, cromatografia líquida de alta eficiência e cromatografia gasosa (ARVOUET-GRAND et al., 1995; BANKOVA; POPOV; MAREKOV., 1982; FRANCO; KUREBAYASHI, 1986; KOO; PARK, 1997; VANHAELEN; VANHAELE-FASTRÉ, 1979; WOISKY, 1996). 
A detecção e a separação cromatográfica de substâncias complexas e resinosas, como a própolis, são incomparavelmente mais difíceis do que as de outras substâncias. Isto se deve pelo fato de os extratos de própolis conterem resina e misturas complexas de substâncias, que apresentam variadas concentrações e polaridades (BURDOCK, 1998; FRANCO, 2001; MARKHAM et al., 1996).

A cromatografia em papel foi usada principalmente no passado para a determinação de flavonóides isolados, sendo um método lento, com baixa resolução e pequena precisão. A cromatografia em camada delgada é uma técnica que também tem sido muito aplicada nas análises de flavonóides, sendo considerada como um método analítico mais rápido e de melhor resolução em relação à cromatografia em papel. No entanto, a cromatografia em camada delgada é uma técnica sem precisão quantitativa, quando não automatizada (MARKHAM, 1982; HEIMLER, 1986; SABATIER et al., 1992; VENNAT et al., 1995; KROL et al., 1996).

Entre os vários métodos cromatográficos usados para a separação e análise de misturas complexas de fenólicos naturais, a cromatografia gasosa com coluna capilar (CGC) é de grande importância devido a sua sensibilidade e poder de resolução. Entretanto, a análise de alguns destes compostos, como, por exemplo, os flavonóides, requer uma fase preliminar de derivados, transformado-os em compostos voláteis. Trabalhos recentes mostraram que a utilização de detector de captura de elétrons ou CGC acoplado a espectrômetro de massas possibilita a análise de alguns flavonóides aglicônicos não derivatizados (BANKOVA et al.,1987; BANKOVA et al.,1992a; BANKOVA et al.,1992b; CHRISTOV; BANKOVA,1992; BANKOVA et al., 1995).

Outra técnica muito utilizada para quantificar os compostos fenólicos presentes própolis é a cromatografia em camada delgada, cromatografia líquida de 
alta eficiência ou combinação entre os dois métodos (BANKOVA; MARCUCCI, 2000).

Os métodos espectrofotométricos usuais para a identificação de flavonóides são a espectrofotometria no ultravioleta (UV), no infravermelho (IV) e a ressonância magnética nuclear de hidrogênio $\left({ }^{1} \mathrm{H}\right)$ e carbono $\left({ }^{13} \mathrm{C}\right)$. A espectrofotometria de UV é considerada a técnica mais simples para análise estrutural dos flavonóides, sendo utilizada para identificação do tipo de flavonóide. Uma análise quantitativa dos flavonóides totais baseada na espectrofotometria no UV é realizada através da formação de complexos com alguns reagentes como $\mathrm{AlCl}_{3}, \mathrm{SbCl}_{3}$ e $\mathrm{ZrOCl}$ (FRANCO; KUREBAYASFFI, 1986; BANKOVA et al., 1992b; NIKOLOVSKACOLESKA et al., 1996; WOISKY, 1996; BANSKOTA et al.,1998; PEREIRA et al., 1998).

Em 1974, a Cromatografia Líquida de Alta Eficiência (CLAE) foi aplicada pela primeira vez para análise de flavonóides e desde então, pesquisadores a tem aplicado, pois consiste em uma técnica versátil que possibilita a separação desses compostos com resultados satisfatórios. Esta técnica tem como vantagem à possibilidade de fornecer um procedimento rápido para identificação e determinação sensivel e precisa de flavonóides e pode ser usada também na caracterização desses compostos. Alguns aparelhos de CLAE, possuindo detectores de arranjo de diodos, tornam possíveis a associação direta do espectro U.V./vis ao pico específico. Recentemente, a CLAE tem sido usada com sucesso para o isolamento, identificação e quantificação de flavonóides da própolis, mel e outros produtos da colméia (BANKOVA; POPOV; MAREKOV, 1982; DONDI et al., 1984; BANKOVA et al.,1987; BOGDANOV,1989; CAMPOS et al.,1990; FERRERES et al., 1991; SABATIER et al.,1992; AGA et al., 1994; GIL et al.,1995; PARK et al.,1995; 
VENNAT et al.,1995; MARKHAM et al., 1996; SIESS et al., 1996; KOO; PARK, 1997; MARTOS et al.,1997; ZUANAZZI,1999).

A CLAE é também bastante empregada nas análises de identificação das possiveis origens botânicas da própolis, comparando-se os perfis químicos obtidos com as análises de amostras de própolis e de resinas vegetais coletadas de plantas localizadas próximas às colméias (BANKOVA et al., 1992a; GIL et al., 1995; KOO; PARK, 1997; MARTOS et al., 1997; SOLER et al., 1995; BANKOVA et al., 1998). A cromatografia líquida com detector massa tem sido utilizada para a identificação de um grande número de compostos da própolis (PIETTA, P.; GARDANA; PETTA, A., 2002).

\subsection{6- Controle de qualidade}

A efetiva introdução da própolis no mercado depende da implementação de condições padronizadas para a coleta e procedimentos sistemáticos para seu controle físico, químico e microbiológico. A ampla variedade e complexidade de sua composição química tornam este critério mais importante no seu controle de qualidade (WOISKY; SALATINO, 1998).

A demanda crescente no consumo da própolis como suplemento alimentar, principalmente a partir do início da década de 90 , vem exigindo o estabelecimento de normas de controle de qualidade até então inexistentes, principalmente, para atender e competir no mercado internacional. Nesse sentido, as entidades governamentais, responsáveis por essa área, desenvolveram e estabeleceram regulamento técnico de identidade e qualidade de produtos apícolas, incluindo a própolis bruta e o extrato de própolis. Esta legislação (Instrução Normativa $n^{\circ} 3$ ) foi publicada em Janeiro de 2001(BRASIL, 2001). 
As principais análises físico-quimicas encontradas na literatura, para o controle de qualidade da própolis são (MARCUCCl et al, 1998):

a) Análises macroscópicas: aspectos gerais como cor, aparência (viscosa, mais dura, etc.), cheiro, etc.

b) Teor de cera: todas as amostras de própolis apresentam cera em sua composição, cujo teor pode variar de uma amostra para outra.

c) Teor de resíduo: o teor de resíduo seco insolúvel em álcool etílico também pode variar de uma amostra para outra.

d) Teor de extrato etanólico (EEP): é o obtido quando se faz a maceração da própolis em álcool etílico, após a retirada da cera e do resíduo.

e) Umidade: é importante avaliar o teor de umidade, pois, se a amostra estiver com este índice elevado, ocorrerá o crescimento de fungos sobre a mesma (especialmente quando se retira do freezer e se embala), e se tornará imprópria para o consumo e comércio.

f) Teor de cinzas: é toda matéria de origem mineral existente na amostra. O teor de cinzas é obtido ao se calcinar a própolis, eliminando-se toda a matéria orgânica. No material resultante estão presentes metais como potássio, chumbo, cádmio, cobre, zinco, estanho, entre outros.

g) Propriedades redutoras (índice de redução): após um determinado período de tempo, a amostra passa a exercer o poder antioxidante. Por este motivo, a própolis é utilizada em alguns países como antioxidante em embalagens de alimentos.

h) Fenólicos totais: substâncias fenólicas como ácidos (caféico, ferúlico, pcumárico, etc.), ésteres (cafeato de feniletila, p-cumarato de benzila, etc.) e flavonóides (quercetina, canferol, galangina, pinocembrina, etc.). 
i) Flavonóides totais: é a determinação específica da presença de flavonóides em própolis avaliada pelo teor de quercetina.

j) Massa mecânica: resíduo remanescente da extração dos componentes da própolis com álcool etílico.

Os requisitos físico-químicos e provas qualitativas indicadas pela legislação brasileira vigente para o padrão de identidade e qualidade da própolis bruta são (BRASIL, 2001):

Requisitos físico-químicos:

- Umidade (perda por dessecação): máximo de $8 \%(\mathrm{~m} / \mathrm{m})$;

- Cinzas: máximo de $5 \%(\mathrm{~m} / \mathrm{m})$;

- Cera: máximo de $25 \%(\mathrm{~m} / \mathrm{m})$;

- Massa mecânica: máximo de $40 \%$;

- Compostos fenólicos: mínimo de 5\% (m/m);

- Flavonóides: mínimo de 0,5\%; $(\mathrm{m} / \mathrm{m})$;

- Atividade de oxidação: máximo de 22 segundos;

- Solúveis em etanol: mínimo de $35 \%(\mathrm{~m} / \mathrm{m})$.

Provas Qualitativas:

- Espectros de absorção de radiações ultravioleta e visível: a própolis deverá apresentar picos característicos das principais classes de flavonóides entre 200 e $400 \mathrm{~nm}$;

- Acetato de chumbo: positivo;

- Hidróxido de sódio: positivo 
Os requisitos físico-químicos propostos pela legislação brasileira para o padrão de identidade e qualidade do extrato alcoólico de própolis são (BRASIL, 2001):

- Extrato seco: mínimo de $11 \%(\mathrm{~m} / \mathrm{v})$;

- Cera: máximo 15 de extrato seco $(\mathrm{m} / \mathrm{m})$;

- Flavonóides: mínimo de 0,25\% (m/m);

- Compostos fenólicos: minimo 0,50\% (m/m);

- Atividade de oxidação: máximo de 22 segundos;

- Teor alcoólico: máximo de $70^{\circ} \mathrm{GL}(\mathrm{v} / \mathrm{v})$;

- Metanol: máximo 0,40 mg/L

\subsection{Artepillin-C}

O artepillin-C foi isolado e identificado por Aga et al (1994) sendo um ácido fenólico, construído a partir de anéis únicos e possui dois grupos prenil (Figura 12), isolado como um constituinte principal $(>5 \%)$ a partir da própolis brasileira. Este ácido fenólico possui atividades biológicas importantes como, por exemplo, antitumoral, anticancerígeno (MIDORIKAWA et al., 2003) e atividades antioxidantes anti-inflamatória, antiviral, antifúngico (SHIMIZU et al., 2004), que mostram que o artepillin $\mathrm{C}$ pode ser um dos importantes princípios ativos da própolis brasileira. $\mathrm{Na}$ verdade, a sua importância tem sido crescentemente reconhecida e recentemente foi definido como padrão de qualidade da própolis brasileira (UTO et al., 2002).

Estudos realizados por Nakashi et al (2003), demonstraram possíveis mecanismos envolvidos na reação de transferência de hidrogênio do artepillin-C para radicais ativos, bem como quantificaram sua habilidade na captura de radicais livres. 
<smiles>CC(C)=CCc1cc(/C=C/C(=O)O)cc(CC=C(C)C)c1O</smiles>

Nome químico: ácido 3,5-diprenil-4-hidroxicinâmico

Figura 12- Estrutura química do artepillin-C (SHIMIZU et al, 2004).

\subsubsection{Metodologias utilizadas para a determinação de Artepillin-C em própolis}

Alguns métodos já foram descritos para a determinação de Artepillin-C em própolis bruta.

Hayashi et al. (1999) analisaram artepillin-C através de técnica cromatográfica (CLAE), utilizando uma coluna de fase reversa C-18 ODS-A de $150 \times 4,6 \mathrm{~mm}$ de dimensão com tamanho de partícula de $5 \mu \mathrm{m}$ e acoplado a um detector ultravioleta operando a $280 \mathrm{~nm}$, em um sistema isocrático usando como fase móvel uma mistura de água:metanol:ácido acético $(32: 65: 3) \mathrm{v} / \mathrm{v}$.

Kumazawa et al (2003) analisaram artepillin-C através da técnica de cromatografia líquida de alta eficiência (CLAE), utilizando uma coluna Capcell Pak UG $120 / C_{18}(250 \times 2,0 \mathrm{~mm})$ com tamanho de partícula de $5 \mu \mathrm{m}$ e um detector de arranjo de fotodiodo, em um sistema gradiente usando como fase móvel uma mistura de ácido acético $2 \%$ (solvente A) e acetonitrila com $2 \%$ de ácido acético 
(solvente B).

Negri, Salatino, M. e Salatino, A. (2003) identificaram a estrutura do artepilinC através da técnica de cromatografia gasosa, acoplado a um espectrômetro de massa, utilizando uma coluna capilar $(30 \times 0.25) \mathrm{mm}$, modo de injeção "split" e um detector operando no modo "scanning".

Park et al. (2004) analisaram Artepillin-C através da técrica de cromatografia líquida de alta eficiência (CLAE). Neste estudo foi utilizado uma coluna de fase reversa YMC PACK ODS $(250 \times 4,6 \mathrm{~mm})$ com tamanho de partícula de $5 \mu \mathrm{m}$ e um detector de arranjo de fotodiodo a $260 \mathrm{~nm}$, em um sistema gradiente usando como fase móvel uma mistura de água (solvente A) e metanol (solvente B).

Shimizu (2004) analisou artepillin-C através da técnica de cromatografia líquida de alta eficiência (CLAE), utilizando uma coluna Capcell Pak UG 120 (250 x 4,6 $\mathrm{mm}$ ) com tamanho de partícula de $5 \mu \mathrm{m}$, um detector arranjo de fotodiodo operando em uma faixa de 220 a $400 \mathrm{nnm}$, em um sistema gradiente usando como fase móvel uma mistura de fosfato de sódio (solvente A) e metanol (solvente B). 


\section{MATERIAL E MÉTODOS}

\subsection{MATERIAL}

\subsubsection{Coleta das amostras de própolis}

As amostras de própolis bruta foram obtidas, aleatoriamente, de apicultores e entrepostos das regiões Nordeste, Centro-Oeste, Sudeste e Sul do Brasil, no periodo de 2003 a 2005, conforme Tabela 1. As amostras foram coletadas por raspagem das partes internas, bordas da melgueira, ninho e tampas das colméias (informações fornecidas pelos apicultores) (Figura 13). As amostras número 1 (Mucuri) e 3 (Palmeiras) foram provenientes de manguezal. Todo material foi previamente acondicionado em pequenos sacos plásticos limpos, inertes e secos, devidamente identificado e armazenado sob o abrigo de luz, a $5^{\circ} \mathrm{C}$. Para melhor visualização das regiões de coleta da própolis bruta, estas foram distribuídas em um mapa (Figura 14).
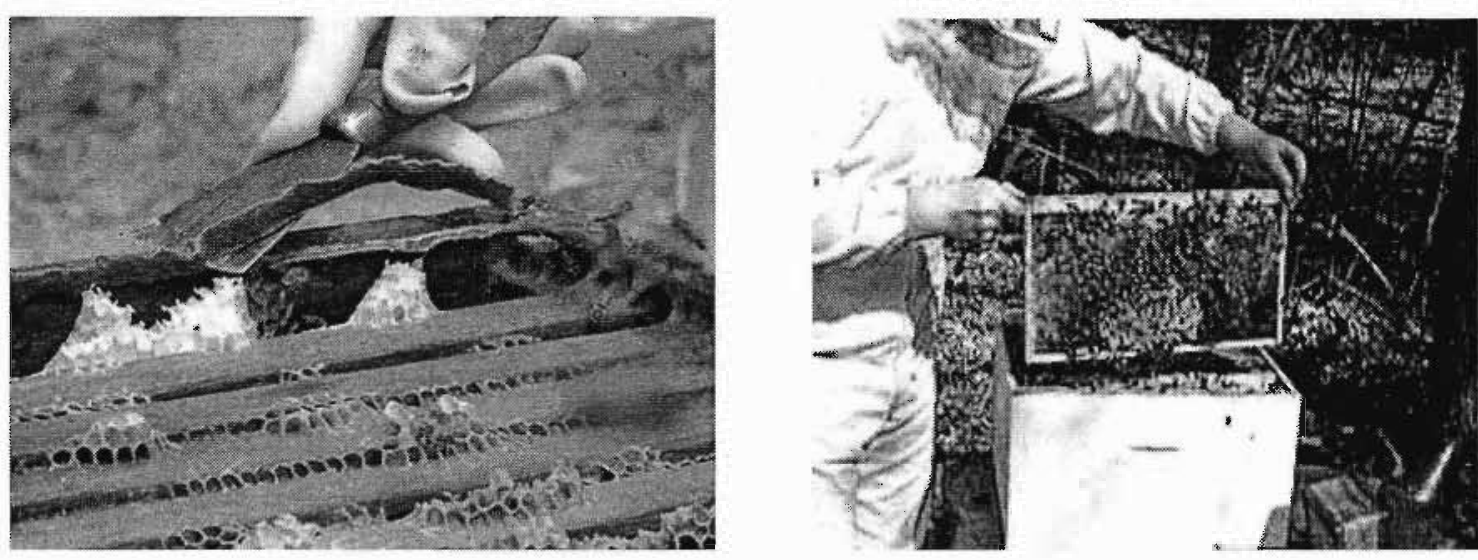

Figura 13 - Coleta de própolis por raspagem (Fonte: Apiário MNH - Paraíbuna). 


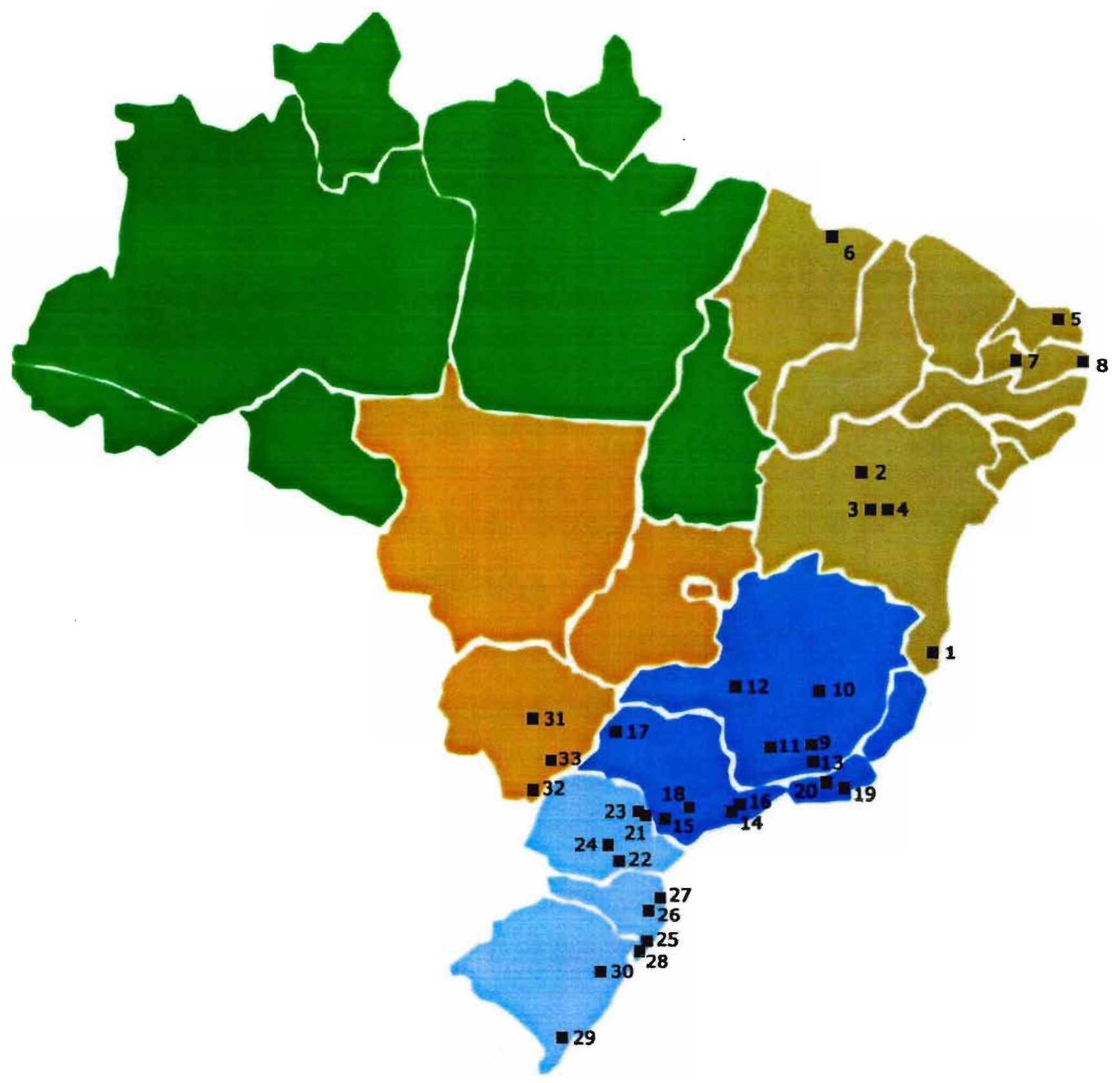

1 - Mucuri
2 - Irecê
3 - Palmeiras
4 - Lençóis
$\mathbf{5}$ - João Câmara
6 - São Luiz
7 - Santa Terezinha
$\mathbf{8}$ - João Pessoa
9 - Barbacena
10 - Itabira
11 - Lavras

1 - Mucuri

3 - Palmeiras

4 - Lençóis

5 - João Câmara

6 - São Luiz

8 - João Pessoa

10 - Itabira

11 - Lavras

\author{
12 - Patrocínio \\ 13 - Juiz de Fora \\ 14 - Salesópolis \\ 15 - Barra do Chapéu \\ 16 - Paraibúna \\ 17 - Cajamar \\ 18 - Pilar do Sul \\ 19 - Itaboraí \\ 20 - Paraiba do Sul \\ 21 - São José da Boa Vista \\ 22 - São Mateus do Sul
}

23 - Wenceslau Brás

24 - Ivaí

25 - Içara

26 - Anitápolis

27 - Itajaí

28 - Araranguá

29 - Pelotas

30 - Taquara

31 - Campo Grande

32 - Mundo Novo

33 - Angélica

Figura 14 - Mapa de distribuição dos pontos de coleta das amostras de própolis, obtidas no período de $2003-2005$. 
Tabela 1 - Localidades de amostragem de própolis bruta nas diversas regiões brasileiras.

\begin{tabular}{|c|c|c|}
\hline Estado/Região & Município & $\begin{array}{l}\text { Identificação das } \\
\text { Amostras }\end{array}$ \\
\hline \multicolumn{3}{|l|}{ Nordeste } \\
\hline Bahia & Mucuri, Irecê, Palmeiras, Lençóis & $1,2,3,4$ \\
\hline Rio Grande do Norte & João Câmara & 5 \\
\hline Maranhão & São Luiz & 6 \\
\hline Paraíba & Santa Terezinha, João Pessoa & 7,8 \\
\hline \multicolumn{3}{|l|}{ Sudeste } \\
\hline Minas Gerais & $\begin{array}{l}\text { Barbacena, Itabira, Lavras, } \\
\text { Patrocínio, Juiz de Fora }\end{array}$ & $9,10,11,12,13$ \\
\hline São Paulo & $\begin{array}{l}\text { Salesópolis, Barra do Chapéu, } \\
\text { Paraíbuna, Cajamar, Pilar do Sul }\end{array}$ & $14,15,16,17,18$ \\
\hline Rio de Janeiro & Itaboraí, Paraíba do Sul & 19,20 \\
\hline \multicolumn{3}{|l|}{ Sul } \\
\hline Paraná & $\begin{array}{l}\text { São José da Boa Vista, São } \\
\text { Mateus do Sul, Wenceslau Brás, } \\
\text { Ivaí }\end{array}$ & $21,22,23,24$ \\
\hline Santa Catarina & Içara, Anitápolis, Itajaí, Araranguá & $25,26,27,28$ \\
\hline Rio Grande do Sul & Pelotas, Taquara & 29,30 \\
\hline \multicolumn{3}{|l|}{ Centro-Oeste } \\
\hline Mato Grosso do Sul & $\begin{array}{l}\text { Campo Grande, Mundo Novo, } \\
\text { Angélica }\end{array}$ & $31,32,33$ \\
\hline
\end{tabular}




\subsubsection{Padrões e Reagentes}

Foram utilizados padrões de artepillin-C, Quercetina e ácido gálico, todos da marca Wako Pure Chemical.

Para o preparo da amostra e da fase móvel foram utilizados reagentes com grau de pureza HPLC e PA: álcool etílico, metanol, acetonitrila, ácido fosfórico, nitrato de alumínio, acetato de potássio, ácido sulfúrico e permanganato de potássio, todos da marca Merck.

Para a determinação quantitativa de compostos fenólicos foi utilizado nitrato de alumínio, acetato de potássio, álcool etilico, carbonato de sódio, todos da marca Merck e reagente de Folin-Ciocalteau (F-9252) da marca Sigma.

Para análise da atividade antioxidante foi utilizado $\beta$-caroteno (C-9750), ácido linoléico (L-2376), Tween-40, hidroxibutiltolueno (BHT), todos da marca Sigma e clorofórmio da marca Merck.

Para realização da análise polínica foi utilizado glicerina da marca Difco, hidróxido de potássio, álcool etílico, fucsina básica, á cido a cético g lacial, a nidrido acético e ácido sulfúrico, todos da marca Merck.

Foi utilizado sistema de água marca Millipore, modelo Milli-Q PLUS, para obtenção de uma água ultrapura.

Os reagentes utilizados para a preparação da fase móvel foram filtrados em membrana $0,45 \mu \mathrm{m}$ de porosidade da marca Millipore.

\subsubsection{Tratamento das amostras de própolis bruta}

As amostras de própolis bruta foram limpas retirando-se a poeira, pedaços de madeira, abelhas mortas, traças e qualquer outro tipo de material estranho. Em 
seguida, foram trituradas, peneiradas em tamis de 18 "mesh" (1000 micras), homogeneizadas, pesadas e armazenadas, a $5^{\circ} \mathrm{C}$.

\subsubsection{Preparo dos extratos etanólicos de própolis (EEP)}

O método para a obtenção do extrato etanólico de própolis foi baseado no procedimento de Park et al. (1995), com modificações.

Para o preparo dos extratos etanólicos de própolis (EEP) foi pesado em balança analítica 0,3 grama de própolis triturada, previamente desidratada em estufa a $60^{\circ} \mathrm{C}$. Em seguida, transferiu-se para tubos de centrifuga e adicionou-se $15 \mathrm{~mL}$ de uma solução de etanol a $80 \%$ e incubados sob agitação por 10 minutos. Após a incubação, a mistura foi centrifugada a $3000 \mathrm{rpm}$ por 3 minutos em centrífuga (Hermle Z 320) e o sobrenadante foi filtrado através de papel de filtro (Advantec 5A com $0,06 \mathrm{mg}$ cinzas $/ 90 \mathrm{~mm}$ ) para um balão volumétrico de $50 \mathrm{~mL}$. O procedimento acima foi repetido por mais três vezes, porém nas três extrações seguintes foram utilizados $10 \mathrm{~mL}$ de solução de álcool etílico a $80 \%$. Os extratos foram misturados e o volume do balão foi completado com solução de álcool etílico a $80 \%$, obtendo-se o extrato etanólico de própolis (EEP). O diagrama esquemático do procedimento de extração pode ser visualizado na Figura 15. 


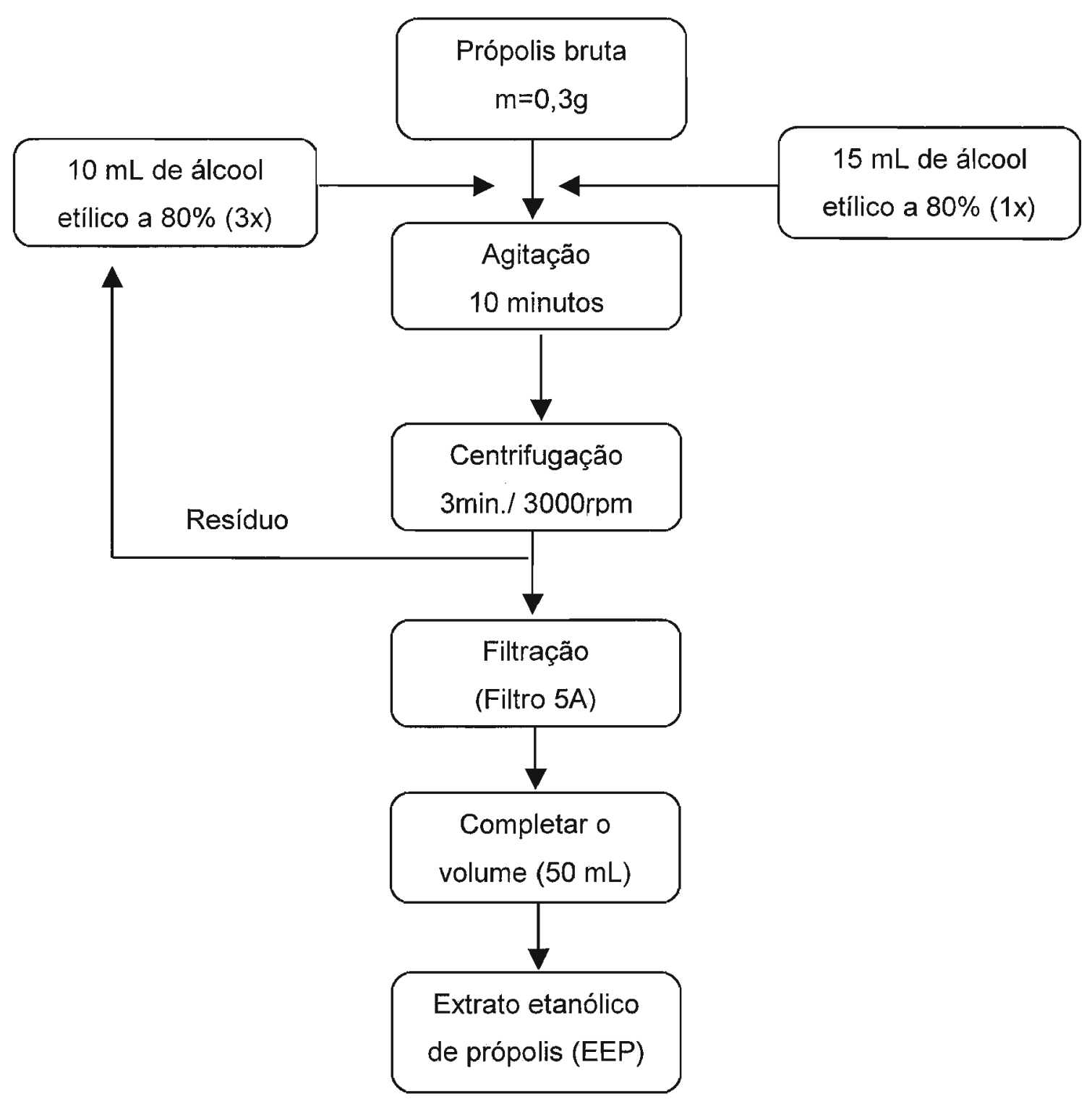

Figura 15: Diagrama esquemático do procedimento de obtenção do EEP

\subsubsection{Preparo dos extratos metanólicos de própolis (EMP)}

Para o preparo dos extratos metanólicos de própolis (EMP) foi pesado em balança analítica 0,4 gramas de própolis triturada, previamente desidratada em estufa a $60^{\circ} \mathrm{C}$. Em seguida, transferiu-se para balão de fundo chato e adicionou-se $20 \mathrm{~mL}$ de metanol. A extração foi feita a $60^{\circ} \mathrm{C}$, em banho de água termostatizado, por 1 hora, sob agitação constante. Em seguida, foi feita uma centrifugação a 3000 
rpm por 10 minutos em centrifuga (Hermle $Z$ 320). Os extratos foram filtrados através de papel de filtro (Advantec $5 \mathrm{~A}$ com $0,06 \mathrm{mg}$ cinzas $/ 90 \mathrm{~mm}$ ) para tubos de ensaio. Ao resíduo foram adicionados $20 \mathrm{~mL}$ de metanol e a extração foi realizada mais uma vez nas mesmas condições. Os sobrenadantes obtidos das duas extrações foram homogeneizados e armazenados em frascos âmbar, a $5^{\circ} \mathrm{C} . \mathrm{O}$ diagrama esquemático do procedimento de extração pode ser visualizado na Figura 16.

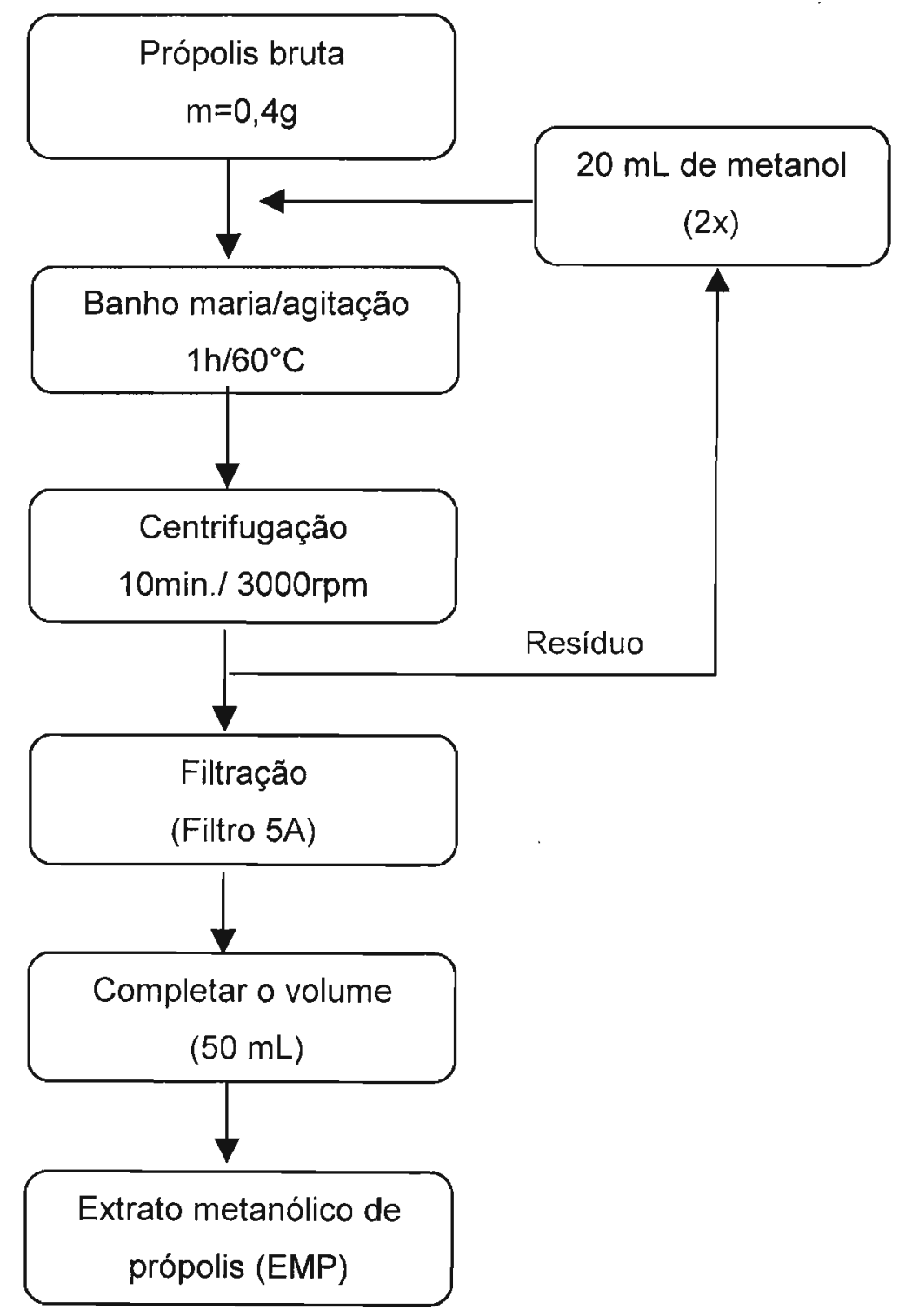

Figura 16: Diagrama esquemático do procedimento de obtenção do EMP. 


\subsection{MÉTODOS}

\subsubsection{Análises indicadas pela Legislação Brasileira para o padrão de identidade e qualidade (PIQ) da própolis bruta.}

\subsubsection{Determinação do teor de umidade}

A análise do teor de umidade foi realizada por gravimetria pela técnica de perda por secagem sob infravermelho utilizando-se um analisador de umidade modelo MA 45 marca Sartorius (BRASIL, 2001; GARCIA-AMOEDO; ALMEIDAMURADIAN, 2002). Pesou-se 2,0g de amostra e ajustou-se a balança a uma intensidade da radiação emitida de modo que a amostra atingisse $105^{\circ} \mathrm{C}$. Os resultados foram expressos em $\mathrm{g} / 100 \mathrm{~g}$ de amostra.

\subsubsection{Determinação de resíduo mineral fixo (Cinzas)}

A determinação do resíduo mineral fixo foi realizada por gravimetria (BRASIL, 2001; INSTITUTO ADOLFO LUTZ, 1985).

Pesou-se $1 \mathrm{~g}$ de amostra de própolis, em cadinho de porcelana, previamente aquecido em mufla a $550^{\circ} \mathrm{C}$, resfriado em dessecador até temperatura ambiente e pesado. A amostra foi submetida a aquecimento e dessecação prévia em estufa a $105^{\circ} \mathrm{C}$ por 2 horas; em seguida foi submetida ao processo de incineração em mufla a $550^{\circ} \mathrm{C}$ até peso constante (quando a diferença entre duas pesagens consecutivas não exceder $5,0 \mathrm{mg}$ ). Os resultados foram expressos em $\mathrm{g} / 100 \mathrm{~g}$ de amostra. 


\subsubsection{Determinação do teor de cera}

O teor de cera foi determinado seguindo o método descrito pela legislação brasileira (BRASIL 2001). Para tanto, uma alíquota de $1,0 \mathrm{~g}\left(\mathrm{P}_{1}\right)$ de cada amostra de própolis, previamente triturada, foi pesada em cartucho de celulose e extraída em aparelho Soxhlet com $110 \mathrm{~mL}$ etanol absoluto por 6 horas. Após este processo, o extrato obtido foi deixado a $5^{\circ} \mathrm{C}$ por 24 horas. Em seguida, foi realizado uma filtração a frio através de papel de filtro $\mathrm{n}^{\circ} 03$, previamente pesado $\left(\mathrm{P}_{2}\right)$. O papel de filtro foi seco em estufa a $105^{\circ} \mathrm{C}$ e em seguida foi colocado em dessecador até peso constante. Após a fitração o papel foi novamente pesado $\left(\mathrm{P}_{3}\right) \mathrm{O}$ s resultados foram expressos em $\mathrm{g} / 100 \mathrm{~g}$ de amostra.

Cálculo da porcentagem de cera:

$$
\% \text { Cera }=\frac{\left(P_{3}-P_{2}\right)}{P_{1}}
$$

Onde: $P_{1}=$ massa inicial da amostra $(g)$

$\mathrm{P}_{2}=$ peso do papel de filtro $(\mathrm{g})$

$\mathrm{P}_{3}=$ peso do papel de filtro + cera $(\mathrm{g})$

\subsubsection{Determinação da massa mecânica}

A partir do resíduo de própolis obtido no item 4.2.1.3, foi determinado a massa mecânica. Para tanto, o cartucho contendo o resíduo foi seco em estufa a $80^{\circ} \mathrm{C}$ por 2 horas e em seguida foi colocado em dessecador e pesado. Este procedimento foi repetido até peso constante (BRASIL, 2001; FÓRUM NACIONAL DE AGRICULTURA, 1997). Os resultados foram expressos em $\mathrm{g} / 100 \mathrm{~g}$ de amostra. 


\subsubsection{Determinação de substâncias solúveis em etanol}

A partir do extrato etanólico (EEP) obtido no item 4.1.4, foi determinado a quantidade de substâncias solúveis em etanol. Em pesa-filtro previamente tarado, foram pesados $3,0 \mathrm{~g}$ de extrato etanólico. A amostra foi evaporada até secura em banho-maria, sob agitação ocasional e em seguida o resíduo foi seco em estufa à temperatura de $105^{\circ} \mathrm{C}$ até peso constante (BRASIL, 2001). Os resultados foram expressos em $\mathrm{g} / 100 \mathrm{~g}$ de amostra.

\subsubsection{Determinação do índice de oxidação}

Para a determinação do índice de oxidação foi pesado $0,2 \mathrm{~g}$ de amostra de própolis bruta, dissolvida em $5 \mathrm{~mL}$ de álcool etílico e deixada em repouso por 1 hora à temperatura ambiente. Após este período, foram acrescentados $100 \mathrm{~mL}$ de água destilada e a solução foi filtrada em papel de filtro $n^{\circ} 3$. A partir do filtrado obtido foi transferido $1 \mathrm{~mL}$ de cada amostra para um béquer de $250 \mathrm{~mL}$. A essa amostra foi adicionada $40 \mathrm{~mL}$ de água destilada e $1,0 \mathrm{~mL}$ do ácido sulfúrico $20 \%$. A mistura foi agitada por 1 minuto e depois foi acrescentado $5 \mu \mathrm{L}$ de permanganato de potássio 0,1N. Com o auxílio de um cronômetro foi medido o tempo, em segundos, que corresponde ao tempo gasto para o desaparecimento da cor rosa, a qual determina o índice de oxidação (BRASIL, 2001; FÓRUM NACIONAL DE AGRICULTURA, 1997). 


\subsubsection{Determinação qualitativa dos compostos fenólicos por espectrofotometria na região ultravioleta-visivel (UV-Scanning)}

A determinação do espectro de absorção dos extratos etanólicos de própolis preconizado pela legislação brasileira (BRASIL, 2001) foi realizado segundo o método descrito por Park et al. (2000). Alíquotas de $25 \mu \mathrm{L}$ de cada extrato EEP obtido de acordo com o item 4.1.4, foram diluídas em $10 \mathrm{~mL}$ de etanol e os espectros de absorção na região UV-visível foram determinados na faixa de comprimento de onda de 195 a 450nm, em espectrofotômetro Shimadzu (modelo UV-1700).

\subsubsection{Determinação quantitativa dos compostos fenólicos presentes no extrato etanólico de própolis}

\subsection{Determinação de flavonóides totais com base em quercetina}

A determinação de flavonóides totais com base em quercetina, preconizada pela legislação brasileira (BRASIL, 2001), foi realizada de acordo com a metodologia descrita no Boletim Informativo da Associação Japonesa de Saúde e Nutrição (1994) e por Ikegaki (2001).

Esse método baseia-se na formação de complexos entre o alumínio e alguns flavonóides, ocasionando um efeito batocrômico, o que leva a um aumento do comprimento de onda de absorção desses compostos (JURD; GEISSAN, 1956). Estes complexos têm máxima absorção nos comprimentos de onda próximo a 415 rım que corresponde à banda de absorção do complexo quercetina-alumínio utilizado como padrão.

A curva de calibração foi feita usando-se uma solução padrão de quercetina 
$1 \mathrm{mg} / \mathrm{mL}$ em etanol absoluto, no intervalo de $0,01-0,2 \mathrm{mg} / \mathrm{mL}$. Foi estabelecida a equação da reta utilizando-se o método da regressão linear.

Em pequenos frascos de vidro contendo alíquotas de $0,5 \mathrm{~mL}$ do extrato etanólico de própolis, preparado de acordo com o item 4.1.4, previamente diluídas quando necessário, foram adicionados $4,3 \mathrm{~mL}$ de álcool etílico $80 \%$, sendo em seguida adicionados $0,10 \mathrm{~mL}$ de solução de acetato de potássio na concentração de $1 \mathrm{M}$ e $0,10 \mathrm{~mL}$ de uma solução de nitrato de alumínio $10 \%(\mathrm{~m} / \mathrm{v})$. O frasco controle (branco) foi preparado nas mesmas condições, porém sem adição de nitrato de alumínio. Em seguida, os frascos foram agitados e deixados em repouso no escuro por 40 minutos, para reação. A absorbância das amostras foi medida em espectrofotômetro Shimadzu (modelo UV-1700) em comprimento de onda de $425 \mathrm{~nm}$, em cubetas de vidro de $1 \mathrm{~cm}$ de caminho óptico.

O teor de flavonóides foi calculado conforme a seguinte fórmula:

$\mathrm{TF}=\frac{\mathrm{C} \times \mathrm{FD}}{\mathrm{m}} \quad \mathrm{Ou} \quad \% \mathrm{TF}=\frac{\mathrm{C}(\mathrm{mg} / \mathrm{mL}) \times 100}{\mathrm{~d}}$

Onde: $T F=$ Teor de flavonóides totais em quercetina expresso em $\mathrm{mg} / \mathrm{g}$ ou porcentagem (\%) de amostra seca;

$\mathrm{C}=$ concentração;

$\mathrm{FD}=$ Fator de diluição;

$\mathrm{m}=$ massa de própolis testada $(\mathrm{g})$

$\mathrm{d}=$ densidade do extrato $(\mathrm{g} / \mathrm{mL})$. 


\subsection{Determinação de compostos fenólicos com base em ácido gálico}

A determinação dos compostos fenólicos totais, com base em ácido gálico, foi realizada de acordo com a metodologia descrita por Woisky (1996) e Marcucci (1998).

Este método baseia-se em uma reação de óxido-redução, onde o íon fenolato é oxidado em meio alcalino, enquanto ocorre a redução do complexo fosfotúngsticofosfomolíbdico no reagente para uma coloração azul (cromóforo), que é absorvida a 760nm (WATERMAN; MOLE, 1994).

A curva de calibração foi feita usando-se uma solução padrão de ácido gálico $1 \mathrm{mg} / \mathrm{mL}$ em etanol, no intervalo de $0,1-1,5 \mathrm{mg} / \mathrm{mL}$. Foi estabelecida a equação da reta utilizando-se o método da regressão linear.

Em balão volumétrico de $5 \mathrm{~mL}$ foi adicionado $20 \mu \mathrm{L}$ do extrato etanólico de própolis, preparado de acordo com o item 4.1.4, previamente diluídos quando necessário, $250 \mu \mathrm{L}$ do reagente de Folin-Ciocalteau, esperou-se 3 minutos e em seguida foi adicionado $500 \mu \mathrm{L}$ de carbonato de sódio na concentração de $20 \%$ e completou-se o volume com água ultra pura. O frasco controle (branco) foi preparado nas mesmas condições acima descritas, porém sem adição do extrato. Em seguida, os frascos foram agitados e deixados em repouso no escuro por 2 horas, para reação. A absorbância das amostras foi medida em espectrofotômetro Shimadzu (modelo UV-1700) em comprimento de onda de 760nm, em cubetas de vidro de $1 \mathrm{~cm}$ de caminho óptico.

O teor de fenólicos totais em ácido gálico foi calculado conforme a seguinte fórmula: 
B।L.....

Faculdade de Ciências Farmacéulićas

- Universidade de São Paulo

$\%$ Fenólicos $=$ Abs $\times$ coef. Angular $\times$ FD

$\mathrm{m}$

Onde: Abs = absorbância;

$\mathrm{FD}=$ Fator de diluição;

$\mathrm{m}$ = massa de própolis testada $(\mathrm{g})$

\subsubsection{Determinação da atividade antioxidante}

A Atividade antioxidante foi determinada pela oxidação acoplada do sistema $\beta$-caroteno/ácido linoléico, de acordo com Kumazawa et al. (2004) e Alencar (2002). Em um béquer foram adicionados $20 \mu \mathrm{L}$ de $\beta$-caroteno, $40 \mu \mathrm{L}$ de ácido linoléico e $300 \mathrm{mg}$ de Tween 40 , os quais foram dissolvidos em $1 \mathrm{~mL}$ de clorofórmio que foi evaporado posteriormente sob nitrogêriio. O resíduo obtido da evaporação foi dissolvido em $100 \mathrm{~mL}$ de água deionizada oxigenada. Alíquotas de $5 \mathrm{~mL}$ da solução ( $\beta$-caroteno) foram transferidas para tubos de ensaio contendo uma alíquota do extrato metanólico de própolis equivalente à concentração de 100ppm. Os tubos foram incubados a $40^{\circ} \mathrm{C}$ para a reação de oxidação e a leitura da absorbância foi feita em espectrofotômetro a 470nm em intervalos de 60 minutos durante o período de 3 horas, sendo que a primeira leitura foi realizada à temperatura ambiente.

Todas as determinações foram feitas em triplicatas e acompanhadas por um controle sem antioxidantes e outro com solução de BHT. A atividade antioxidante foi calculada através da seguinte fórmula: 


$$
\% \mathrm{AA}=100-\frac{\text { (decaimento de absorbância da amostra) })}{\text { (decaimento de absorbância do controle) }} \times 100
$$

Onde: $\mathrm{AA}=$ Porcentagem da atividade antioxidante.

\subsubsection{Análise polínica}

A análise polínica das amostras de própolis bruta foi realizada de acordo com a metodologia de Barth $(1998,1999)$.

Para a obtenção dos grãos de pólen foi utilizado $0,50 \mathrm{~g}$ de própolis triturada, acondicionada em tubo de ensaio, adicionado $15 \mathrm{~mL}$ de álcool etílico absoluto, permanecendo em repouso por, no mínimo, 24 horas, agitando-se ocasionalmente. O etanol foi removido por centrifugação (15 minutos) e o material foi dividido em dois tubos de centrífuga de $15 \mathrm{~mL}$ cada. Ao resíduo foram adicionados $13 \mathrm{~mL}$ de etanol absoluto a cada tubo e o processo foi repetido novamente. Após centrifugação, adicionou-se $12 \mathrm{~mL}$ da solução de hidróxido de potássio a $10 \%$, deixando reagir por 3 minutos em banho-maria à temperatura de $90^{\circ} \mathrm{C}$. Para evitar a formação de grumos e facilitar a liberação do pólen foi aplicado, aos tubos ainda quentes, ultrassom por 5 minutos. Após sonificação, os tubos foram centrifugados e o sedimento foi lavado com $13 \mathrm{~mL}$ de água destilada e filtrado em tela de malha $(0,3 \mathrm{~mm}$ de abertura) para a retirada de pedaços graúdos, seguido de uma centrifugação. Após a centrifugação, foram adicionados $5 \mathrm{~mL}$ de ácido acético glacial, permanecendo uma noite. Após nova centrifugação foi realizada a acetólise, ou seja, a oxidação do sedimento em uma mistura de anidrido acético e ácido sulfúrico (9:1) em banho-maria até alcançar a temperatura de $80^{\circ} \mathrm{C}$ por cerca de três minutos. Após cuidadosa lavagem em água destilada $(2 x)$ e em água-glicerinada 
(por 30 minutos), preparou-se o sedimento sobre duas lâminas de microscopia em gelatina-glicerinada, com ou sem corante (fucsina básica), vedando-se com parafina. Para a observação de pêlos vegetais preparou-se uma lâmina do sedimento antes da aplicação da mistura de acetólise.

A identificação dos grãos de pólen e respectivas interpretações relacionadas à vegetação foi fundamentada em dados da literatura, baseados em Barth (2004).

\subsubsection{Determinação de artepillin-C por cromatografia líquida de alta eficiência} (CLAE)

A análise por CLAE em fase reversa dos extratos metanólicos de própolis (EMP) foi baseado no procedimento por Hayashi et al. (1999), com modificações na fase móvel.

Vinte microlitros de cada extrato metanólico da própolis, preparado de acordo com o item 4.1.5, foi filtrado em membrana de celulose de $0,45 \mu \mathrm{m}$ e injetado em um cromatógrafo líquido (Shimadzu modelo SPD-10A), equipado com coluna de fase reversa (C-18 ODS-A, modelo Shimpack CLC-ODS de $150 \times 4,6 \mathrm{~mm}$ de dimensão com tamanho de partícula de $5 \mu \mathrm{m}$ ) acoplado a um detector ultravioleta (modelo SPD-10AVP com faixa de comprimento de onda $190-600 \mathrm{~nm}$ ) operando a $280 \mathrm{~nm}$, duas bombas (modelo LC-10AVP), desgaseificador de membrana (modelo DGU12A marca Shimadzu), sistema de integração e sistema de injeção manual.

Utilizou-se sistema isocrático com fase móvel constituída de acetonitrila / ácido fosfórico $0,1 \%(1: 1, v / v)$, com vazão de fluxo constante de $1 \mathrm{~mL} / \mathrm{min}$. Entre as análises, foi realizada a limpeza da coluna por 20 minutos, no qual se deixava eluir apenas fase móvel para garantir a saida de todas as substâncias que ainda 
poderiam estar na coluna. A coluna foi mantida a uma temperatura constante de $25^{\circ} \mathrm{C}$ e os cromatogramas foram processados utilizando software CLASS-VP 6.12 SP5 (Shimadzu). O artepillin-C foi identificado pelo espectro de absorção na região ultravioleta, pela comparação do tempo de retenção e padronização externa. As condições cromatográficas podem ser visualizadas na Tabela 2.

Tabela 2 - Condições cromatográficas para determinação de artepillin-C

\begin{tabular}{c|c}
\hline Parâmetros & Condições \\
\hline Coluna & $\begin{array}{c}\mathrm{C}_{18}, \text { esférica, } 5 \mu \mathrm{m}, 150 \times 4,6 \mathrm{~mm} \text { com pré- } \\
\text { coluna Shimadzu }\end{array}$ \\
\hline Fase Móvel & acetonitrila / ácido fosfórico $0,1 \%(1: 1, \mathrm{v} / \mathrm{v})$ \\
\hline Detector & Ultravioleta (UV) $-\lambda=280 \mathrm{~nm}$ \\
\hline Fluxo da fase móvel & $1,0 \mathrm{~mL} / \mathrm{min}$ \\
\hline Volume de injeção & $20 \mu \mathrm{L}$ \\
\hline Temperatura & $25^{\circ} \mathrm{C}$ \\
\hline
\end{tabular}

\subsubsection{Validação da metodologia de determinação de Artepillin-C}

A validação do método proposto consiste na avaliação dos seguintes parâmetros: linearidade, limite de detecção, limite de quantificação, precisão, exatidão, descritos a seguir. 


\subsection{Linearidade}

Visando determinar a capacidade do método cromatográfico (CLAE) em gerar resultados proporcionais à concentração da amostra, foi verificada a linearidade do mesmo. A linearidade estabelece a relação existente entre a resposta do sistema cromatográfico e a concentração do analito que está sendo analisado (BRENDOLAN, 2000).

A linearidade do método foi determinada através da obtenção da curva de calibração do artepillin-C. Foi preparada uma solução estoque em metanol na concentração de $100 \mu \mathrm{g} / \mathrm{mL}$. Em seguida, foram preparadas as diluições $(0,05 ; 0,1$; 0,$5 ; 1,0 ; 5,0 ; 10,0 ; 15,0 \mu \mathrm{g} / \mathrm{mL}$ ) em metanol, filtradas com membrana de porosidade $0,45 \mu \mathrm{m}$ (Millipore) e analisada por CLAE conforme item 4.2.3. Para cada concentração foram realizadas cinco determinações.

A linearidade foi verificada fazendo a análise de regressão representada pela equação da reta, e através do coeficiente de correlação ou do coeficiente de determinação ( $\left.\mathrm{r}^{2}\right)$ (CHASIN et al., 1998).

\subsection{Limite de detecção e de quantificação}

Limite de determinação ou quantificação é o menor valor determinado, em confiabilidade de precisão e exatidão aceitáveis, para uma dada condição analitica, enquanto que limite de detecção é a menor quantidade do analito que pode ser detectada, com segurança e sem a necessidade de uma quantificação (LEITE, 1998).

O limite de detecção (LD) e o limite de quantificação (LQ) foram determinados a partir dos resultados do desvio padrão médio e da inclinação da 
curva de calibração. A análises para cada concentração foram realizadas em 5 replicatas. O cálculo para o $L D$ e $L Q$ foi realizado segundo as seguintes fórmulas (SWARTZ; KRULL, 1998), (VIAL; JARDY, 1999):

\begin{tabular}{l}
\hline$L D=\frac{\text { desvio padrão médio }}{\text { inclinação da curva de calibração }} \times 3$ \\
$L Q=\frac{\text { desvio padrão médio }}{\text { inclinação da curva de calibração }} \times 10$
\end{tabular}

\subsection{Precisão}

Precisão é um termo geral para avaliar a dispersão de resultados entre ensaios independentes (INMETRO, 2003). É o parâmetro que avalia a proximidade entre várias medidas efetuadas em uma mesma amostra (CHASIN et al, 1998).

Para medir a precisão do método utilizado foi determinado o teor de artepillin-C, seis vezes, em uma amostra de própolis originária da região de Minas Gerais, de concentração conhecida. Esta medida foi realizada em condições de repetitividade, ou seja, usando a mesma amostra, o mesmo reagente, no mesmo laboratório, com o mesmo equipamento e pelo mesmo operador em um curto intervalo de tempo (CHASIN et al., 1998). A precisão foi expressa em função do desvio padrão (DP) e do coeficiente de variação (CV).

\subsection{Exatidão}

A exatidão representa o grau de concordância entre os resultados individuais 
encontrados em um determinado ensaio e um valor aceito como verdadeiro (ICH Q2B, 2004). Os processo mais utilizados para determinar a exatidão de um método são: material de referência; comparação de métodos; ensaios de recuperação; adição de padrão.

A exatidão foi determinada através do cálculo da taxa de recuperação para o método cromatográfico utilizado. A recuperação foi obtida pelo método de adição de padrão, em quatro níveis de concentração. As amostras foram preparadas em quatro níveis de concentração na faixa de 10 a $100 \%$ da quantidade nominal da amostra, tendo sido realizada uma triplicata para cada nível. As análises foram independentes e completas desde a preparação da amostra até o cálculo do resultado. O cálculo da taxa de recuperação $(R)$ foi realizado pela seguinte fórmula (INMETRO, 2003):

$$
\text { Recuperação }(\%)=\left(\mathrm{C}_{1}-\mathrm{C}_{2}\right) \times 100
$$

$\mathrm{C}_{3}$

Onde: $\mathrm{C}_{1}=$ concentração determinada na amostra adicionada,

$\mathrm{C}_{2}=$ concentração determinada na amostra não adicionada,

$\mathrm{C}_{3}=$ concentração adicionada

\subsubsection{Determinação de artepillin-C em amostras de própolis de diversas regiões do Brasil.}

As amostras de própolis foram analisadas conforme o procedimento descrito no item 4.2.2, para determinação de artepillin-C. A concentração foi expressa em 
porcentagem (\%) segundo a seguinte equação:

$$
\text { Artepillin-C (\%) }=\frac{\underline{\mathrm{C}} \times \mathrm{V} \times \mathrm{d} \times 100}{1000(\mathrm{mg}) \times \text { massa }}
$$

Onde: $C=$ concentração $(\mu \mathrm{g} / \mathrm{mL})$;

$\mathrm{V}=$ volume total amostra $(\mathrm{mL})$;

$\mathrm{m}=$ massa de própolis testada $(\mathrm{mg})$

d = diluição.

\subsection{Análise Estatística}

$\mathrm{Na}$ análise estatística, inicialmente, os valores relativos às analises indicadas pela legislação Brasileira e Artepillin-C foram avaliados quanto à homogeneidade das variâncias através do teste de Hartley, Cochran e Bartlett.

As regiões foram comparadas, inicialmente, em relação a cada característica do estudo através da ANOVA one-way, para a comparação das médias, onde foi verificado que esta técnica não produziu um modelo significativo para algumas características, aplicou-se, então, o teste não paramétrico equivalente, o teste de mediana de Mood. O teste de Mood apresenta um intervalo de confiança de $5 \%$ para a mediana de cada região, tornando possível a ordenação das mesmas. Para a análise de índice de oxidação e flavonóides totais, os dados foram tratados através de ANOVA one-way, seguidos de testes de comparação múltipla (Teste de Tukey) para identificação dos contrastes significativos.

Para a comparação geral entre as regiões considerando todos os parâmetros em estudo, os dados foram tratados através de Balanced MANOVA, seguido pelo 
teste de Tukey. Em todas as análises estatísticas considerou-se um nível de significância $(\alpha)$ de 0,05 na tomada de decisões. Cálculos e gráficos foram realizados utilizando-se o software estatístico MINITAB 14.1.0 (Minitab Inc.).

\subsection{Tratamento dos resíduos químicos}

Todos os resíduos químicos gerados durante este trabalho foram encaminhados para serem incinerados pela empresa AMBICAMP $^{\circledR}$ Assessoria e Gerenciamento Industrial Ltda. 


\section{5- RESULTADOS E DISCUSSÃO}

5.1 - Análises indicadas pela Legislação Brasileira para o padrão de identidade e qualidade (PIQ) da própolis bruta.

\subsection{1- Determinação do teor de umidade}

A própolis para ter padrão de qualidade para comercialização, segundo a legislação brasileira, deve apresentar teor de umidade máximo de $8 \%(\mathrm{~m} / \mathrm{m})$ (BRASIL, 2001).

$\mathrm{Na}$ Tabela 3 estão apresentados os resultados da análise, em triplicata, do teor de umidade das amostras de própolis obtidas de diferentes regiões do Brasil. Houve uma variação de 2,26 a 9,89\%, tendo a amostra número 32 (Santa Terezinha - Paraiba) valor acima do preconizado pela Legislação Brasileira (BRASIL, 2001). 
Tabela 3 - Teor de umidade $(\% \mathrm{~m} / \mathrm{m})$ das amostras de própolis bruta de diferentes regiões do Brasil.

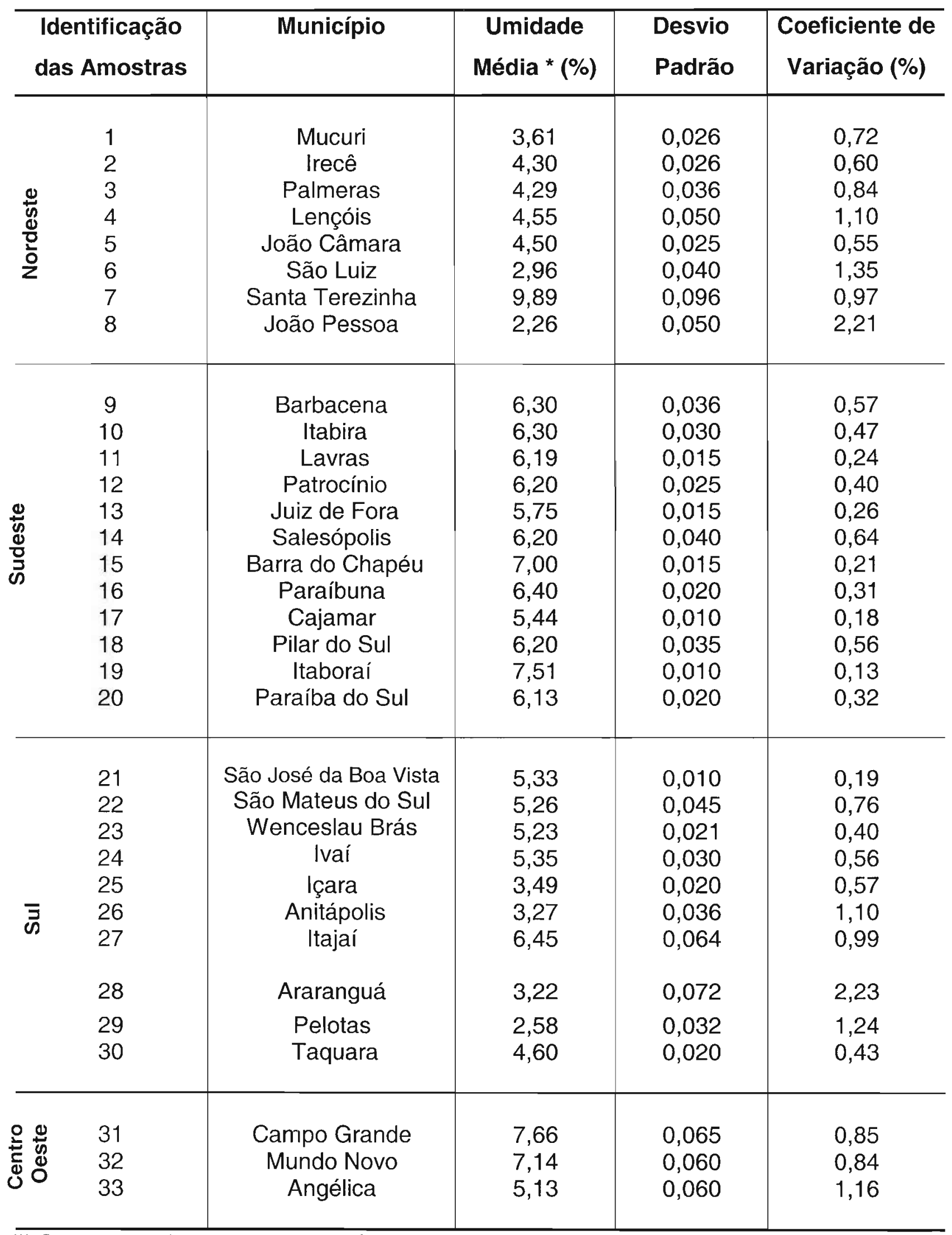

$\left(^{\star}\right)$ Os valores acima representam média de três determinações. 
Bonvehi, Coll e Jordá (1994) avaliaram o teor de umidade de amostras de própolis brasileira encontrando um valor de $22,60 \%$, sendo superior ao valor reportado no presente trabalho.

Franco, Bruschi e Bueno (2000) observaram variações na perda por dessecação de amostras de própolis, do Paraná, coletadas em diferentes estações do ano e locais da colméia, sempre dentro de um limite de 15\%. Observaram ainda, que amostras coletadas no inverno e das partes mais externas das colméias apresentaram maior perda por dessecação. Comparando com os valores obtidos neste trabalho, pode-se inferir que as amostras de própolis obtidas do Paraná foram provavelmente coletadas nos locais mais internos da colméia e bem acondicionadas.

Bruschi (2002) avaliou a perda por dessecação em amostras de própolis da cidade de Maringá (Paraná) obtendo um valor médio de 8,02\%.

Cunha et al (2004) analisaram o teor de umidade em amostras de própolis provenientes de São Paulo e Minas Gerais obtendo valores que variaram de 6,8 a $9,4 \%$ e 7,8 a $9,6 \%$, respectivamente.

O resultado da análise estatística está representado pela Figura 17. 


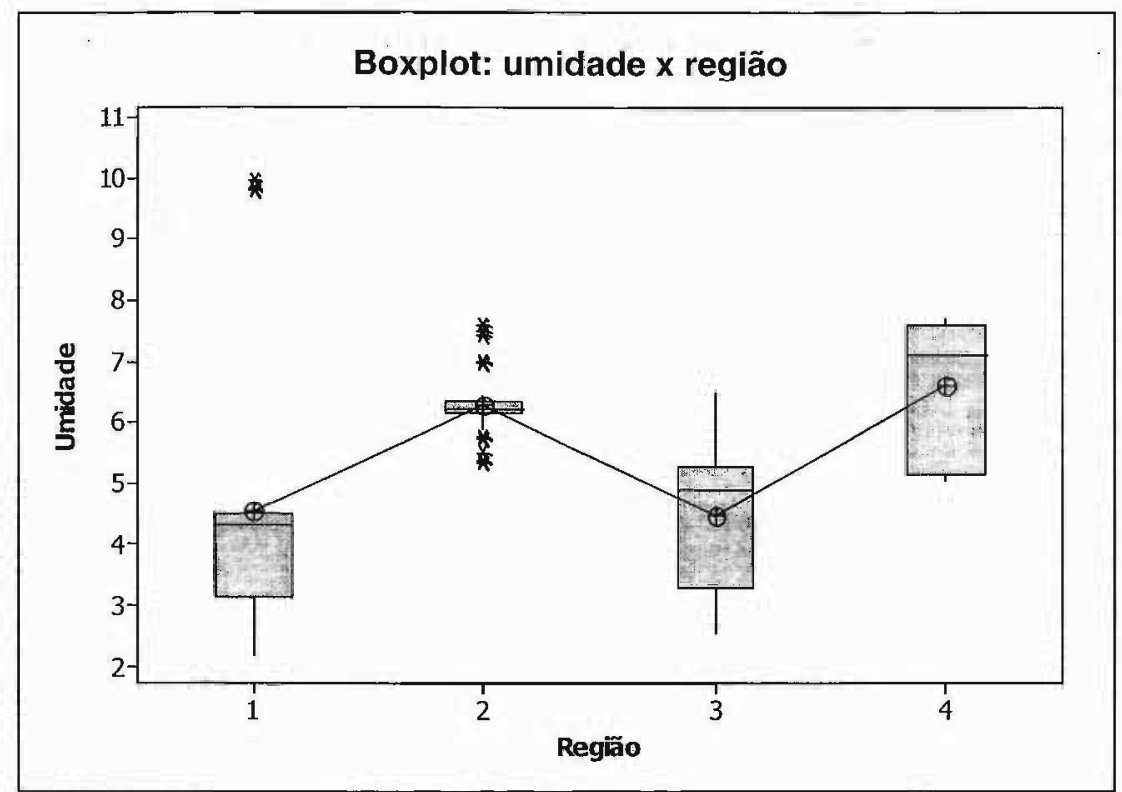

1: Nordeste

2: Sudeste

3: Sul

4: Centro-oeste

Figura 17: Gráfico da relação entre os teores de umidade de amostras de própolis em função das diversas regiões brasileiras.

Na Figura 17 pode-se notar que a região 2 (sudeste) foi a que apresentou menor variabilidade no teor de umidade.

Através do teste de Mood pode-se verificar que as quatro regiões não apresentaram a mediana dos teores de umidade estatisticamente iguais, valor$p=0,000$. A região 1 (nordeste) foi estatisticamente semelhante a região 3 (sul) e apresentou um teor de umidade inferior as demais regiões. A região 2 (sudeste) apresentou mediana de umidade estatisticamente semelhante a região 4 (centrooeste) e superior as regiões 1 e 3 .

O teor de umidade da própolis se torna mais elevado quando esta não é armazenada de forma adequada (WOISKY, 1996) e quando o clima da região é mais úmido (MARCUCCI; BANKOVA, 1999). 


\subsection{2 - Determinação de resíduo mineral fixo (Cinzas)}

O teor de cinzas evidencia o grau de substâncias residuais não voláteis presentes como constituintes naturais da própolis, porém trata-se de um material inorgânico, que em quantidades elevadas pode denunciar adulterações em amostras que se apresentam na forma de pó, feitas com terra, areia ou com outros resíduos.

A própolis para ter padrão de qualidade para comercialização, segundo a legislação brasileira, deve apresentar teor de cinzas máximo de $5 \%(\mathrm{~m} / \mathrm{m})$ (BRASIL, 2001).

Os valores encontrados na determinação, em triplicata, do resíduo mineral fixo (cinzas) das amostras de própolis obtidas de diferentes regiões do Brasil estão apresentados na Tabela 4. 
Tabela 4 - Resíduo mineral fixo $(\% \mathrm{~m} / \mathrm{m})$ de amostras de própolis bruta de diferentes regiões do Brasil.

\begin{tabular}{|c|c|c|c|c|c|}
\hline & $\begin{array}{l}\text { dentificação } \\
\text { as Amostras }\end{array}$ & Município & $\begin{array}{l}\text { Resíduo Mineral } \\
\text { Fixo-Média * }(\%)\end{array}$ & $\begin{array}{l}\text { Desvio } \\
\text { Padrão }\end{array}$ & $\begin{array}{l}\text { Coeficiente de } \\
\text { Variação (\%) }\end{array}$ \\
\hline & $\begin{array}{l}1 \\
2 \\
3 \\
4 \\
5 \\
6 \\
7 \\
8\end{array}$ & $\begin{array}{c}\text { Mucuri } \\
\text { Irecê } \\
\text { Palmeiras } \\
\text { Lençóis } \\
\text { João Câmara } \\
\text { São Luiz } \\
\text { Santa Terezinha } \\
\text { João Pessoa }\end{array}$ & $\begin{array}{l}1,70 \\
2,84 \\
2,27 \\
2,54 \\
3,07 \\
18,7 \\
2,09 \\
3,50\end{array}$ & $\begin{array}{c}0,056 \\
0,058 \\
0,070 \\
0,11 \\
0,090 \\
0,260 \\
0,077 \\
0,100\end{array}$ & $\begin{array}{l}3,29 \\
2,04 \\
3,08 \\
4,33 \\
2,93 \\
1,39 \\
3,68 \\
2,86\end{array}$ \\
\hline & $\begin{array}{c}9 \\
10 \\
11 \\
12 \\
13 \\
14 \\
15 \\
16 \\
17 \\
18 \\
19 \\
20\end{array}$ & $\begin{array}{c}\text { Barbacena } \\
\text { Itabira } \\
\text { Lavras } \\
\text { Patrocínio } \\
\text { Juiz de Fora } \\
\text { Salesópolis } \\
\text { Barra do Chapéu } \\
\text { Paraíbuna } \\
\text { Cajamar } \\
\text { Pilar do Sul } \\
\text { Itaboraí } \\
\text { Paraíba do Sul }\end{array}$ & $\begin{array}{l}2,91 \\
2,90 \\
2,85 \\
2,90 \\
3,03 \\
2,83 \\
2,79 \\
1,95 \\
2,80 \\
2,60 \\
3,26 \\
2,76\end{array}$ & $\begin{array}{l}0,070 \\
0,055 \\
0,062 \\
0,040 \\
0,090 \\
0,055 \\
0,060 \\
0,055 \\
0,040 \\
0,090 \\
0,053 \\
0,052\end{array}$ & $\begin{array}{l}2,40 \\
1,89 \\
2,17 \\
1,38 \\
2,97 \\
1,94 \\
2,15 \\
2,82 \\
1,43 \\
3,46 \\
1,62 \\
1,88\end{array}$ \\
\hline$\overline{\bar{n}}$ & $\begin{array}{l}21 \\
22 \\
23 \\
24 \\
25 \\
26 \\
27 \\
28 \\
29 \\
30\end{array}$ & $\begin{array}{c}\text { São José da Boa Vista } \\
\text { São Mateus do Sul } \\
\text { Wenceslau Brás } \\
\text { Ivaí } \\
\text { Içara } \\
\text { Anitápolis } \\
\text { Itajaí } \\
\text { Araranguá } \\
\text { Pelotas } \\
\text { Taquara }\end{array}$ & $\begin{array}{l}2,91 \\
2,37 \\
3,24 \\
3,43 \\
2,42 \\
2,02 \\
2,77 \\
2,55 \\
1,70 \\
1,56\end{array}$ & $\begin{array}{l}0,086 \\
0,085 \\
0,100 \\
0,085 \\
0,089 \\
0,090 \\
0,081 \\
0,061 \\
0,058 \\
0,060\end{array}$ & $\begin{array}{l}2,95 \\
3,58 \\
3,08 \\
2,48 \\
3,68 \\
4,45 \\
2,92 \\
2,39 \\
3,41 \\
3,84\end{array}$ \\
\hline$\frac{\Phi}{0}$ & $\begin{array}{l}31 \\
32 \\
33\end{array}$ & $\begin{array}{c}\text { Campo Grande } \\
\text { Mundo Novo } \\
\text { Angélica }\end{array}$ & $\begin{array}{l}3,26 \\
3,60 \\
3,51\end{array}$ & $\begin{array}{l}0,090 \\
0,045 \\
0,070\end{array}$ & $\begin{array}{l}2,76 \\
1,25 \\
2,00\end{array}$ \\
\hline
\end{tabular}

$\left.{ }^{*}\right)$ Os valores acima representam média de três determinações. 
As amostras apresentaram um resultado médio de $2,71 \%$, variando entre 1,56 a 3,60\%. A amostra número 4 (São Luiz - Maranhão) apresentou um valor de cinzas de $18,70 \%$, sendo este o único valor acima do preconizado pela Legislação Brasileira (BRASIL, 2001).

Dos resultados da literatura, os valores para o teor de cinzas que mais se aproximaram dos obtidos neste trabalho foram os de Bonvehi, Coll e Jordá (1994), Woisky (1996), Cunha et al (2004) e Funari (2005). Bonvehi, Coll e Jordá avaliaram amostras de própolis do Brasil encontrando valor médio de $3,10 \%$, Woisky utilizou amostras provenientes de São Paulo (2,80\%) e Santa Catarina (2,74\%), Cunha et al analisou amostras de São Paulo e Minas Gerais obtendo valores que variaram de 3,80 a $4,23 \%$ e 2,55 a $3,25 \%$, respectivamente, enquanto que Funari avaliou teor de cinza em amostras da Serra do Japi - São Paulo, encontrando valor médio de $3,12 \%$.

Carmo (1999) avaliou o teor de cinzas em amostras de própolis coletadas no estado de Paraná e em Santa Catarina, obtendo valores médios de 2,05 e 1,80\%, respectivamente.

O resultado da análise estatística está apresentado na Figura 18. 


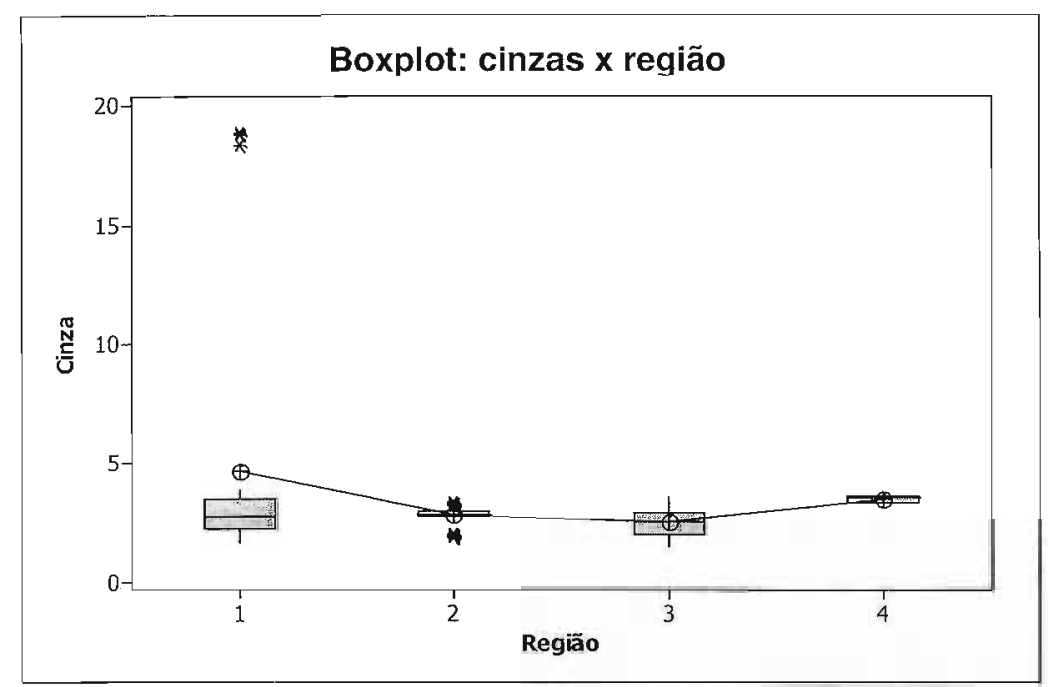

1: Nordeste

2: Sudeste

3: Sul

4: Centro-oeste

Figura 18: Gráfico da relação entre os teores de cinzas de amostras de própolis em função das diversas regiões brasileiras

Analisando a Figura 18 pode-se verificar que a região 1 (nordeste) apresentou dois pontos que podem ser considerados "outliers", pois a presença destes influenciaram no valor da média.

Através do teste de Mood pode-se verificar que as quatro regiões não apresentaram a mediana dos teores de cinzas estatisticamente iguais, valor$p=0,004$. A região 1 (nordeste) foi estatisticamente semelhante a região 2 (sudeste) e 3 (sul) e estas apresentaram mediana inferiores a região 4 (centro-oeste). A região 2 apresentou uma menor dispersão para um intervalo de confiança de 95\% para teor de cinzas.

\subsection{3 - Determinação do Teor de Cera}

A cera presente na própolis é produzida pela própria abelha e acrescentada à resina coletada nas plantas, para a produção da própolis (GHISALBERTI, 1979). Um fator importante para a determinação de cera relaciona-se a possíveis adulterações com a introdução de cera do favo nos extratos de própolis como forma de ganho de 
volume. Em altas quantidades, a presença da cera é a principal causa de turvação dos extratos de própolis, quando armazenados em baixas temperaturas (WOISKY, 1996).

As abelhas podem incorporar mais cera à própolis durante os períodos em que as resinas são escassas ou de difícil coleta e períodos onde a vedação da colméia deve ser muito maior, como no inverno (BURDOCK, 1998; FRANCO; BRUSCHI; BUENO, 2000). É necessário que a análise do teor de cera da própolis seja realizada para cada amostra como controle de qualidade, em função da possibilidade da diminuição do teor de substâncias ativas.

A própolis para ter padrão de qualidade para comercialização, segundo a legislação brasileira, deve apresentar teor de cera máximo de $25 \%(\mathrm{~m} / \mathrm{m})$ (BRASIL, 2001).

Os valores encontrados na determinação, em triplicata, do teor de cera das amostras de própolis obtidas de diferentes regiões do Brasil estão apresentados naTabela 5.

As amostras avaliadas apresentaram teores de cera variando de 2,92 a $14,67 \%$, estando todas dentro do limite estabelecido pela legislação vigente. 
Tabela 5 - Teor de Cera $(\% \mathrm{~m} / \mathrm{m})$ de amostras de própolis bruta de diferentes regiões do Brasil.

\begin{tabular}{|c|c|c|c|c|c|}
\hline & $\begin{array}{l}\text { dentificação } \\
\text { las Amostras }\end{array}$ & Município & $\begin{array}{c}\text { Teor de Cera } \\
\text { Média*(\%) }\end{array}$ & $\begin{array}{l}\text { Desvio } \\
\text { Padrão }\end{array}$ & $\begin{array}{c}\text { Coeficiente de } \\
\text { Variação (\%) }\end{array}$ \\
\hline $\begin{array}{l}\frac{0}{0} \\
0 \\
0 \\
\frac{0}{0} \\
\frac{0}{2}\end{array}$ & $\begin{array}{l}1 \\
2 \\
3 \\
4 \\
5 \\
6 \\
7 \\
8\end{array}$ & $\begin{array}{c}\text { Mucuri } \\
\text { Irecê } \\
\text { Palmeiras } \\
\text { Lençóis } \\
\text { João Câmara } \\
\text { São Luiz } \\
\text { Santa Terezinha } \\
\text { João Pessoa }\end{array}$ & $\begin{array}{c}9,04 \\
11,50 \\
12,43 \\
9,20 \\
6,56 \\
2,92 \\
11,80 \\
8,85\end{array}$ & $\begin{array}{l}0,10 \\
0,16 \\
0,40 \\
0,30 \\
0,19 \\
0,11 \\
0,26 \\
0,30\end{array}$ & $\begin{array}{l}1,11 \\
1,39 \\
3,22 \\
3,26 \\
2,89 \\
3,77 \\
2,20 \\
3,39\end{array}$ \\
\hline & $\begin{array}{c}9 \\
10 \\
11 \\
12 \\
13 \\
14 \\
15 \\
16 \\
17 \\
18 \\
19 \\
20\end{array}$ & $\begin{array}{c}\text { Barbacena } \\
\text { Itabira } \\
\text { Lavras } \\
\text { Patrocínio } \\
\text { Juiz de Fora } \\
\text { Salesópolis } \\
\text { Barra do Chapéu } \\
\text { Paraíbuna } \\
\text { Cajamar } \\
\text { Pilar do Sul } \\
\text { Itaboraí } \\
\text { Paraíba do Sul }\end{array}$ & $\begin{array}{l}7,47 \\
8,36 \\
8,33 \\
7,41 \\
7,65 \\
7,36 \\
6,80 \\
9,33 \\
6,79 \\
9,30 \\
7,76 \\
7,41\end{array}$ & $\begin{array}{c}0,22 \\
0,14 \\
0,15 \\
0,21 \\
0,19 \\
0,15 \\
0,14 \\
0,17 \\
0,13 \\
0,13 \\
0,085 \\
0,18\end{array}$ & $\begin{array}{l}2,94 \\
1,67 \\
1,80 \\
2,83 \\
2,48 \\
2,04 \\
2,06 \\
1,82 \\
1,91 \\
1,40 \\
1,09 \\
2,43\end{array}$ \\
\hline$\overline{\bar{\omega}}$ & $\begin{array}{l}21 \\
22 \\
23 \\
24 \\
25 \\
26 \\
27 \\
28 \\
29 \\
30\end{array}$ & $\begin{array}{c}\text { São José da Boa Vista } \\
\text { São Mateus do Sul } \\
\text { Wenceslau Brás } \\
\text { Ivaí } \\
\text { Içara } \\
\text { Anitápolis } \\
\text { Itajaí } \\
\text { Araranguá } \\
\text { Pelotas } \\
\text { Taquara }\end{array}$ & $\begin{array}{c}5,49 \\
5,87 \\
6,20 \\
6,55 \\
10,0 \\
8,56 \\
10,61 \\
10,35 \\
6,34 \\
7,12\end{array}$ & $\begin{array}{l}0,15 \\
0,12 \\
0,20 \\
0,23 \\
0,12 \\
0,15 \\
0,28 \\
0,28 \\
0,16 \\
0,13\end{array}$ & $\begin{array}{l}2,73 \\
2,04 \\
3,22 \\
3,51 \\
1,20 \\
1,75 \\
2,64 \\
2,70 \\
2,52 \\
1,82\end{array}$ \\
\hline & $\begin{array}{l}31 \\
32 \\
33\end{array}$ & $\begin{array}{c}\text { Campo Grande } \\
\text { Mundo Novo } \\
\text { Angélica }\end{array}$ & $\begin{array}{c}5,62 \\
12,23 \\
14,67\end{array}$ & $\begin{array}{l}0,15 \\
0,25 \\
0,41\end{array}$ & $\begin{array}{l}2,67 \\
2,04 \\
2,79\end{array}$ \\
\hline
\end{tabular}

(*) Os valores acima representam média de três determinações. 
Dos resultados da literatura, os valores que mais se aproximaram dos obtidos neste trabalho foram os de Woisky (1996) e Gregório (2003). Woisky utilizou amostras de própolis provenientes de São Paulo $(7,82 \%)$ e Santa Catarina $(6,79 \%)$, enquanto que Gregório avaliou teor de cera em amostras da cidade de Cajuru - São Paulo, encontrando valores que variaram de 7,44 a $15,76 \%$.

Bastos (2001) avaliou teor de cera em amostras provenientes de Minas Gerais encontrando valores que variaram de 20,86 a $35,53 \%$.

Bruschi (2002) avaliou o teor de cera em amostras de própolis da cidade de Maringá (Paraná) obtendo um valor de 15,16\%.

Funari (2005) avaliou teor de cera em amostras provenientes da Serra do Japi - São Paulo encontrando valor médio de 2,25\%.

O resultado da análise estatística está apresentado na Figura 19.

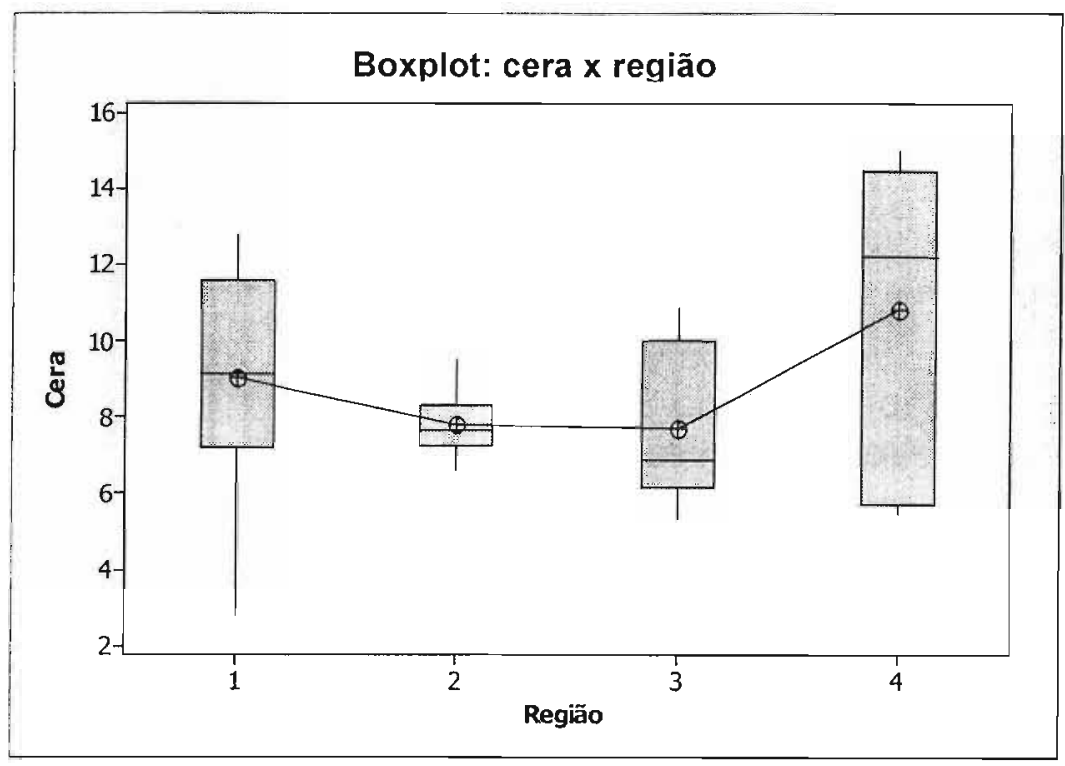

1: Nordeste

2: Sudeste

3: Sul

4: Centro-oeste

Figura 19: Gráfico da relação entre os teores de cera de amostras de própolis em função das diversas regiões brasileiras. 
Analisando a Figura 19 pode-se notar que a regiões 2 (sudeste) e 4 (centrooeste) apresentaram menor e maior variabilidade no teor de cera, respectivamente.

Através do teste de Mood pode-se verificar que as quatro regiões não apresentaram a mediana dos teores de cera estatisticamente iguais, valor $-p=0,012$. A região 1 (nordeste) apresentou mediana estatisticamente semelhante a região 4 (centro-oeste), porém apresenta uma mediana estatisticamente superior às regiões 2 (sudeste) e 3 (sul). A região 2 apresentou uma menor dispersão na mediana do teor de cera e foi estatisticamente semelhante a mediana da região 3.

\subsection{4 - Determinação da massa mecânica}

O teor de massa mecânica refere-se às partículas incorporadas à própolis durante a sua elaboração pelas abelhas ou no processo de sua retirada das colméias (fragmentos de folhas, pedaços de insetos, etc.) (WARAKOMSKA; MACIEJEWIC, 1992).

A quantidade máxima de massa mecânica permitida pela legislação brasileira é de $40 \%(\mathrm{~m} / \mathrm{m})$ (BRASIL, 2001).

Os valores encontrados nas determinações, em triplicata, da massa mecânica das amostras de própolis obtidas de diferentes regiões do Brasil estão apresentados na Tabela 6. 
Tabela 6 - Massa Mecânica $(\% \mathrm{~m} / \mathrm{m})$ de amostras de própolis bruta de diferentes regiões do Brasil

\begin{tabular}{|c|c|c|c|c|c|}
\hline \multicolumn{2}{|c|}{$\begin{array}{l}\text { Identificação } \\
\text { das Amostras }\end{array}$} & Município & $\begin{array}{c}\text { Massa Mecânica } \\
\text { Média * }(\%)\end{array}$ & $\begin{array}{l}\text { Desvio } \\
\text { Padrão }\end{array}$ & $\begin{array}{c}\text { Coeficiente de } \\
\text { Variação (\%) }\end{array}$ \\
\hline $\begin{array}{l}\frac{9}{0} \\
\frac{0}{0} \\
\frac{0}{0} \\
\frac{0}{2}\end{array}$ & $\begin{array}{l}1 \\
2 \\
3 \\
4 \\
5 \\
6 \\
7 \\
8\end{array}$ & $\begin{array}{c}\text { Mucuri } \\
\text { Irecê } \\
\text { Palmeiras } \\
\text { Lençóis } \\
\text { João Câmara } \\
\text { São Luiz } \\
\text { Santa Terezinha } \\
\text { João Pessoa }\end{array}$ & $\begin{array}{l}28,35 \\
31,50 \\
32,76 \\
38,50 \\
29,15 \\
56,81 \\
29,45 \\
26,80\end{array}$ & $\begin{array}{l}0,19 \\
0,10 \\
0,25 \\
0,30 \\
0,25 \\
0,28 \\
0,27 \\
0,26\end{array}$ & $\begin{array}{l}0,67 \\
0,32 \\
0,76 \\
0,78 \\
0,86 \\
0,49 \\
0,91 \\
0,97\end{array}$ \\
\hline 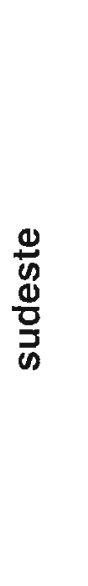 & $\begin{array}{c}9 \\
10 \\
11 \\
12 \\
13 \\
14 \\
15 \\
16 \\
17 \\
18 \\
19 \\
20\end{array}$ & $\begin{array}{c}\text { Barbacena } \\
\text { Itabira } \\
\text { Lavras } \\
\text { Patrocínio } \\
\text { Juiz de Fora } \\
\text { Salesópolis } \\
\text { Barra do Chapéu } \\
\text { Paraíbuna } \\
\text { Cajamar } \\
\text { Pilar do Sul } \\
\text { Itaboraí } \\
\text { Paraíba do Sul }\end{array}$ & $\begin{array}{l}29,65 \\
30,54 \\
29,82 \\
29,89 \\
33,60 \\
33,16 \\
31,23 \\
33,51 \\
33,37 \\
30,33 \\
31,13 \\
30,61\end{array}$ & $\begin{array}{l}0,10 \\
0,10 \\
0,10 \\
0,18 \\
0,10 \\
0,17 \\
0,20 \\
0,11 \\
0,19 \\
0,23 \\
0,12 \\
0,14\end{array}$ & $\begin{array}{l}0,34 \\
0,33 \\
0,33 \\
0,60 \\
0,30 \\
0,51 \\
0,64 \\
0,33 \\
0,57 \\
0,76 \\
0,38 \\
0,46\end{array}$ \\
\hline$\overline{\bar{B}}$ & $\begin{array}{l}21 \\
22 \\
23 \\
24 \\
25 \\
26 \\
27 \\
28 \\
29 \\
30 \\
\end{array}$ & $\begin{array}{c}\text { São José da Boa Vista } \\
\text { São Mateus do Sul } \\
\text { Wenceslau Brás } \\
\text { Ivaí } \\
\text { Içara } \\
\text { Anitápolis } \\
\text { Itajaí } \\
\text { Araranguá } \\
\text { Pelotas } \\
\text { Taquara } \\
\end{array}$ & $\begin{array}{l}34,96 \\
32,65 \\
30,40 \\
32,29 \\
30,66 \\
27,86 \\
29,65 \\
29,22 \\
31,72 \\
28,82 \\
\end{array}$ & $\begin{array}{l}0,10 \\
0,12 \\
0,21 \\
0,20 \\
0,16 \\
0,10 \\
0,24 \\
0,25 \\
0,14 \\
0,20\end{array}$ & $\begin{array}{l}0,28 \\
0,37 \\
0,69 \\
0,62 \\
0,52 \\
0,36 \\
0,81 \\
0,85 \\
0,44 \\
0,69\end{array}$ \\
\hline 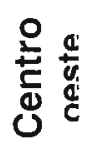 & $\begin{array}{l}31 \\
32 \\
33\end{array}$ & $\begin{array}{c}\text { Campo Grande } \\
\text { Mundo Novo } \\
\text { Angélica }\end{array}$ & $\begin{array}{l}31,90 \\
35,22 \\
37,10\end{array}$ & $\begin{array}{l}0,20 \\
0,22 \\
0,23\end{array}$ & $\begin{array}{l}0,62 \\
0,62 \\
0,62\end{array}$ \\
\hline
\end{tabular}

(*) Os valores acima representam média de três determinações. 
Quase todos os grupos de amostra apresentaram valores que variaram de 26,80 a $38,50 \%$, estando dentro do limite estabelecido pela legislação vigente. A exceção foi a amostra número 4 (56,81\%) de São Luiz (Maranhão) que apresentou um valor superior ao valor máximo permitido pela legislação vigente (40\%).

Bastos (2001) e Matsuda (2002) avaliaram o teor de massa mecânica em amostras de própolis provenientes de Minas Gerais encontrando valores que variaram de 22,25 a $40,73 \%$ e 28,9 a $30,3 \%$, respectivamente.

Funari (2005) avaliou o teor de massa mecânica em amostras provenientes da Serra do Japi - São Paulo encontrando valor médio de 35,22\%, sendo próximo ao valor reportado no presente trabalho para as amostras de Paraíbuna e Salesópolis (São Paulo).

O resultado da análise estatística está apresentado na Figura 20.

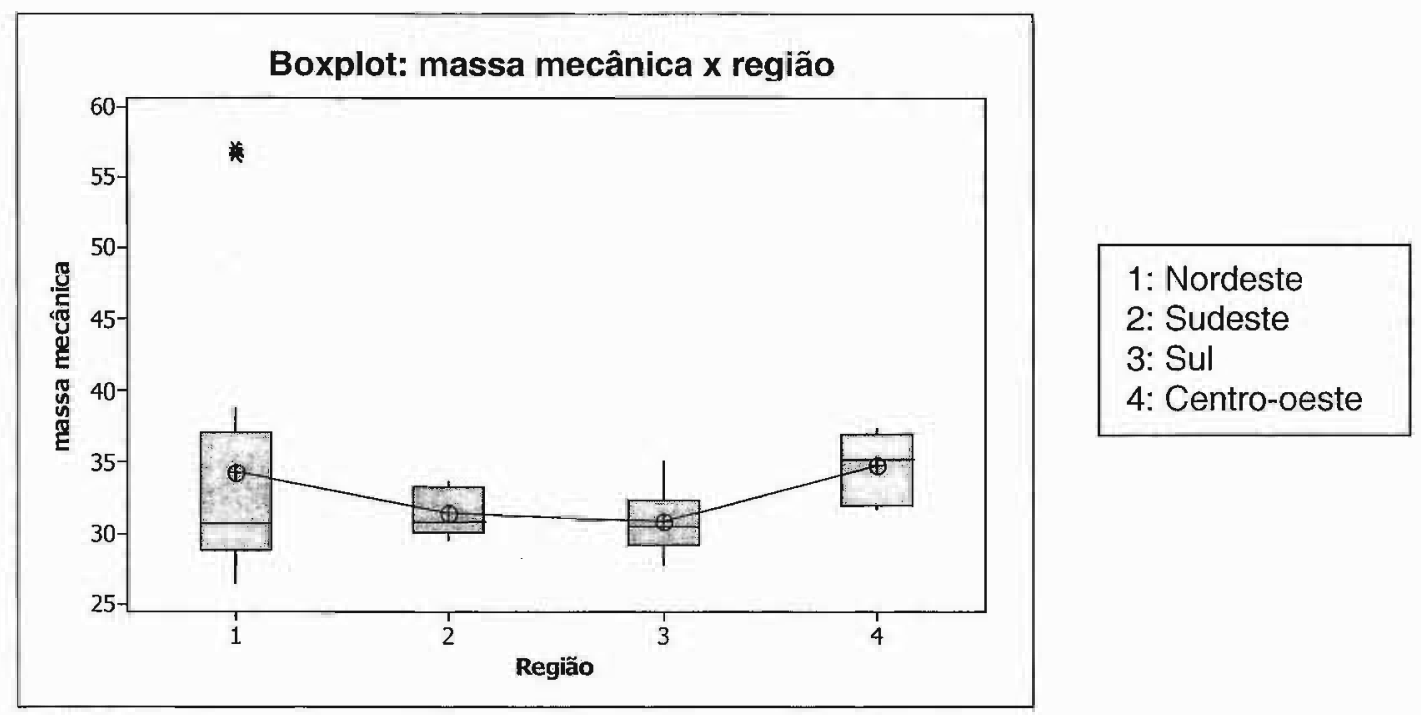

Figura 20: Gráfico da relação entre os teores de massa mecânica de amostras de própolis em função das diversas regiões brasileiras. 
Analisando a Figura 20 pode-se verificar que a região 1 (nordeste) foi a que apresentou maior dispersão nos níveis de massa mecânica.

Através do teste de Mood pode-se verificar que as quatro regiões não apresentaram a mediana dos teores de massa mecânica estatisticamente iguais, valor-p=0,014. A região 2 (sudeste) apresentou uma menor dispersão na mediana dos teores de massa mecânica e foi estatisticamente semelhante a mediana das regiões 1 e 3 (sul). As regiões 2 e 3 apresentam mediana dos níveis de massa mecânica menores que a da região 4 .

\subsection{5 - Determinação de substâncias solúveis em etanol}

A quantidade mínima de substâncias solúveis estabelecida pela legislação brasileira é de 35\% (m/m) (BRASIL, 2001).

Os valores encontrados na determinação das substâncias solúveis em etanol das amostras de própolis obtidas de diferentes regiões do Brasil, realizadas em triplicata, estão apresentados na Tabela 7. Todos os grupos de amostras apresentaram substâncias solúveis que variaram de 35,82 a $63,32 \%$, estando dentro do limite estabelecido pela legislação vigente (BRASIL, 2001). 
Tabela 7 - Teor de substâncias solúveis em etanol $(\% \mathrm{~m} / \mathrm{m})$ de amostras de própolis bruta de diferentes regiões do Brasil.

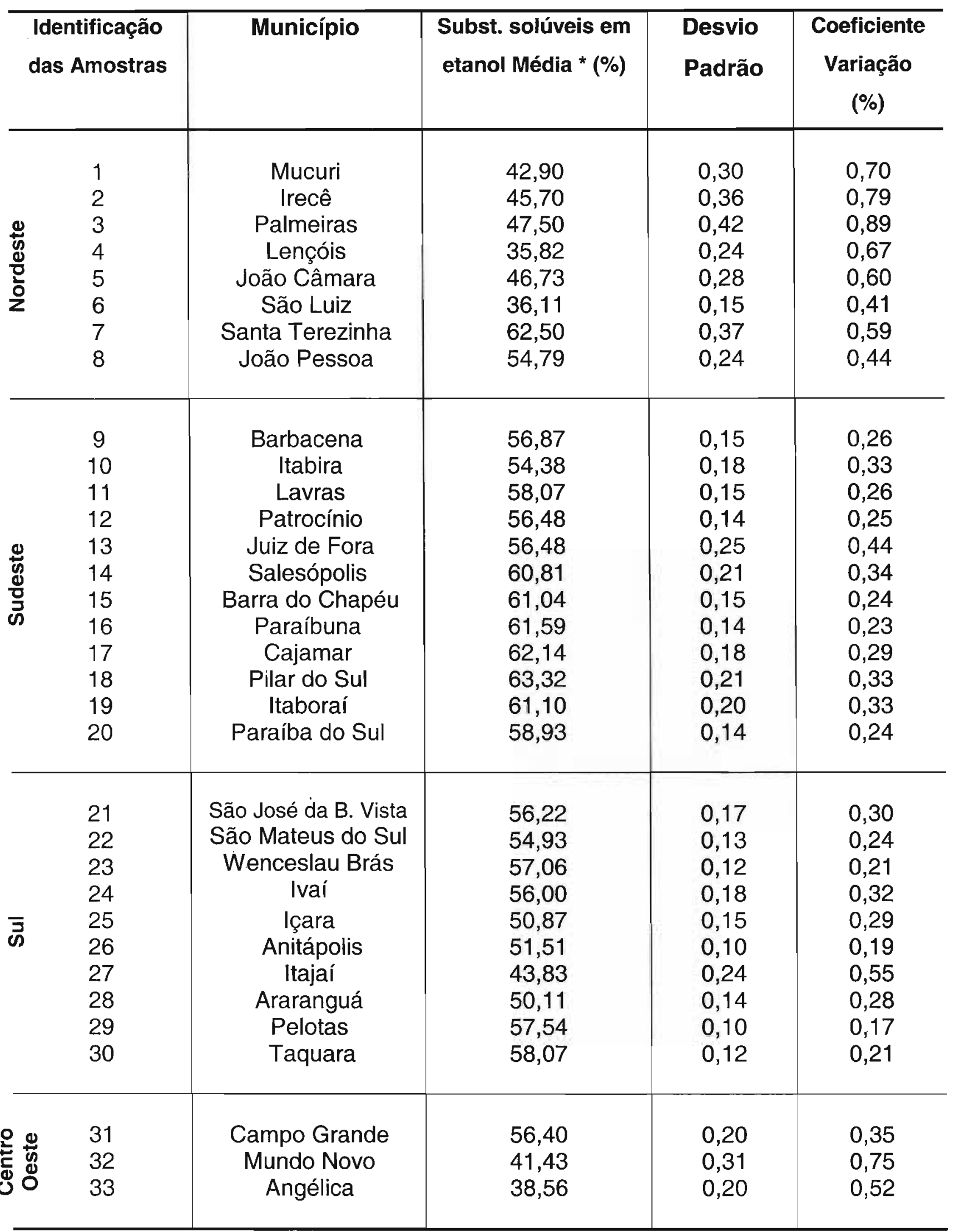

$\left(^{*}\right)$ Os valores acima representam média de três determinações. 
Os resultados obtidos foram semelhantes aos encontrados por Ikegaki (2001) e Alencar (2002). Ikegaki avaliou a quantidade de substâncias solúveis em etanol em amostras de própolis provenientes da região do Sul do Brasil encontrando valores que variaram de 54,5 a $60,5 \%$ e Alencar, avaliou amostras provenientes de diferentes regiões do Brasil (Nordeste, Norte, Sul e Sudeste), encontrando valores que variaram de 24,1 (Nordeste) a $61,0 \%$ (Sudeste).

Funari (2005) avaliou a quantidade de substâncias solúveis em etanol em amostras proveriientes da Serra do Japi - São Paulo encontrando valor médio de $38,34 \%$.

O resultado da análise estatística está apresentado na Figura 21.

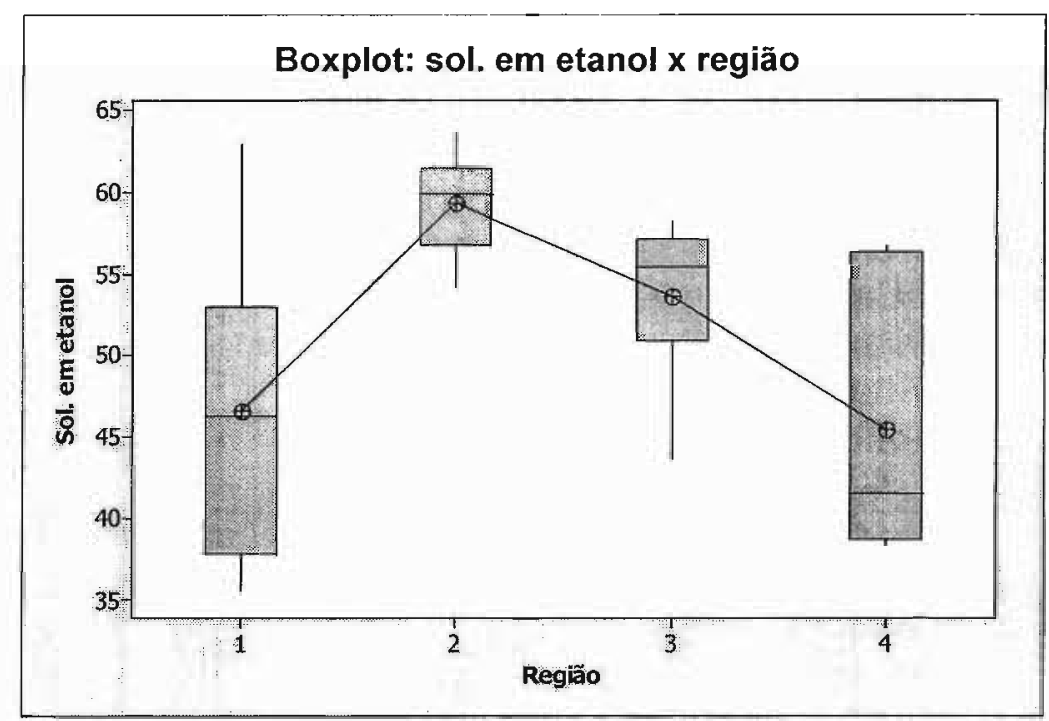

1: Nordeste

2: Sudeste

3: Sul

4: Centro-oeste

Figura 21: Gráfico da relação entre os teores de substâncias solúveis de amostras de própolis em função das diversas regiões brasileiras.

Através da Figura 21 pode-se verificar que a região 2 (sudeste) apresentou valores do teor de substâncias solúveis em etanol superiores aos registrados nas demais regiões, porém com uma menor variabilidade. Já as regiões 1 (nordeste) e 4 (centro-oeste) foram as que apresentaram uma maior variabilidade nos valores 
encontrados.

Através do teste de Mood pode-se verificar que as quatro regiões não apresentaram a mediana do teor de substâncias solúveis em etanol estatisticamente iguais, valor-p=0,000. A região 1 (nordeste) apresentou mediana dos níveis de solúveis em etanol inferior as encontradas nas regiões 2 e 3 (sul), porém estatisticamente semelhante à região 4 (centro-oeste). A região 2 apresentou mediana dos níveis de solúveis em etanol superior e estatisticamente diferente das demais regiões.

\subsection{6 - Determinação do índice de oxidação}

O índice de oxidação da própolis informa a idade desta, o tipo de armazenamento e reflete a sua atividade biológica. Altos índices de oxidação em própolis indicam que a mesma foi armazenada por longo período em temperaturas elevadas, no interior da colméia ou em depósitos de armazenamento (ASIS, 1989).

Os valores encontrados na determinação, em triplicata, do índice de oxidação das amostras de própolis obtidas de diferentes regiões do Brasil estão apresentados na Tabela 8.

As amostras avaliadas apresentaram índice de oxidação variando de 2,0 a 10 segundos, estando todas dentro do limite estabelecido pela legislação vigente de 22 segundos (BRASIL, 2001). 
Tabela 8 - Indice de oxidação (s) das amostras de própolis bruta de diferentes regiões do Brasil.

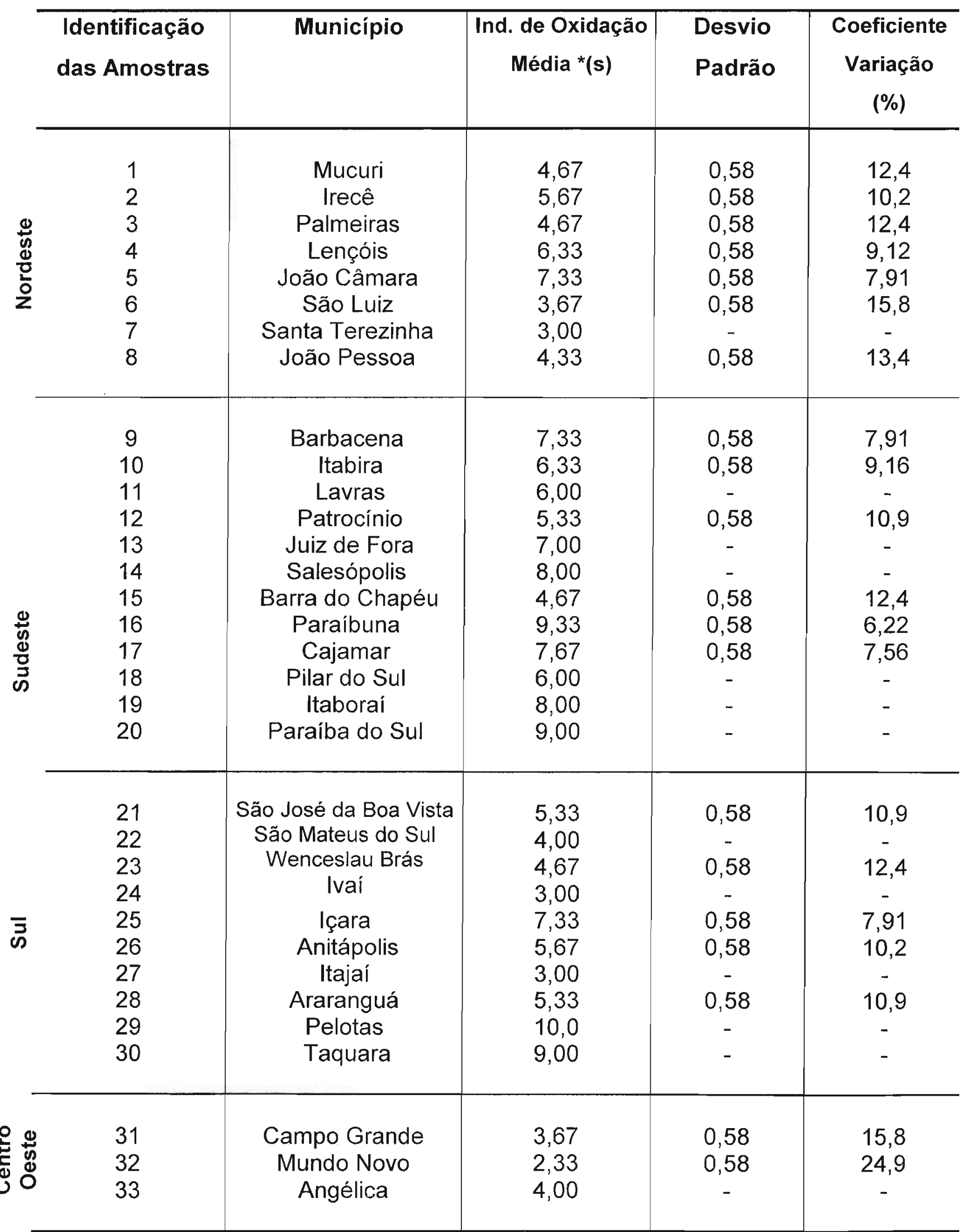

$\left(^{*}\right)$ Os valores acima representam média de três determinações. 
Bonvehi, Coll e Jordá (1994) avaliaram o índice de oxidação de amostras de própolis brasileira encontrando um valor de 80 s, sendo este muito superior ao valor reportado no presente trabalho.

Bastos (2001) avaliou o índice de oxidação de amostras provenientes de Minas Gerais encontrando valores que variaram de 3,3 a 40,6s.

O resultado da análise estatística está apresentado na Figura 22.

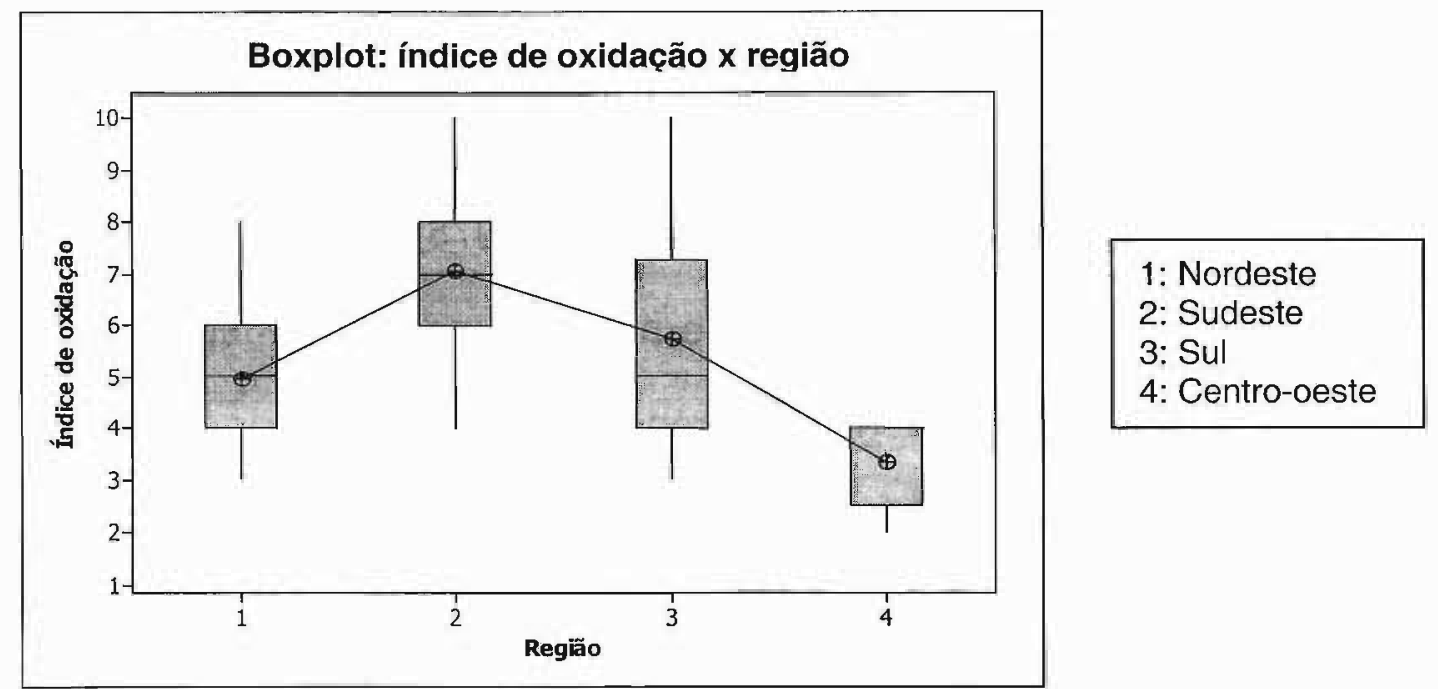

Figura 22: Gráfico da relação entre os índices de oxidação de amostras de própolis em função das diversas regiões brasileiras.

Analisando a Figura 22 pode-se verificar que a região 4 (centro-oeste) foi a que apresentou uma menor variabilidade nos níveis de índice de oxidação.

Através do teste de Tukey pode-se verificar que as quatro regiões não apresentaram a média do índice de oxidação estatisticamente iguais, valor-p=0,000. A região 1 (nordeste) apresentou média dos índices de oxidação estatisticamente semelhante à região 3 (sul). 


\subsection{7 - Determinação qualitativa dos compostos fenólicos por espectrofotometria na região ultravioleta-visível (UV-Scanning)}

Os extratos etanólicos de própolis foram analisados por espectrofotometria na região ultravioleta-visível, de acordo com o método descrito no item 4.2.1.7 estando seus espectros de absorção ilustrados nas Figura 23 a 26.

Cada grupo de amostra de própolis apresentou um valor máximo de absorbância nos comprimentos de onda que variaram de 270 a $315 \mathrm{~nm}$. De um modo geral, os flavonóides também apresentam valores máximos de absorção na faixa de 250 a $350 \mathrm{~nm}$ (MARKHAM, 1975). No entanto, a análise por espectrofotometria dos EEP fornece apenas uma característica geral de todos os compostos fenólicos presentes na própolis.

De acordo com os resultados obtidos, verificou-se que o perfil espectrofotométrico varia para cada região. As amostras de própolis do Rio Grande do Sul e Rio Grande do Norte apresentaram absorção no mesmo valor máximo de comprimento de onda $(270 \mathrm{~nm})$, o mesmo ocorrendo com as amostras de Minas Gerais (Patrocínio), Rio de Janeiro (Paraiba do Sul) e São Paulo (Cajamar), porém no comprimento de onda de $312 \mathrm{~nm}$.

Resultados semelhantes foram obtidos por lkegaki (2001) e Alencar (2002) ao avaliarem o espectro de absorção de amostras de própolis do Rio Grande do Sul.

Pode-se observar que os espectros de absorção das amostras de própolis da região sudeste foram semelhantes aos do Paraná. 

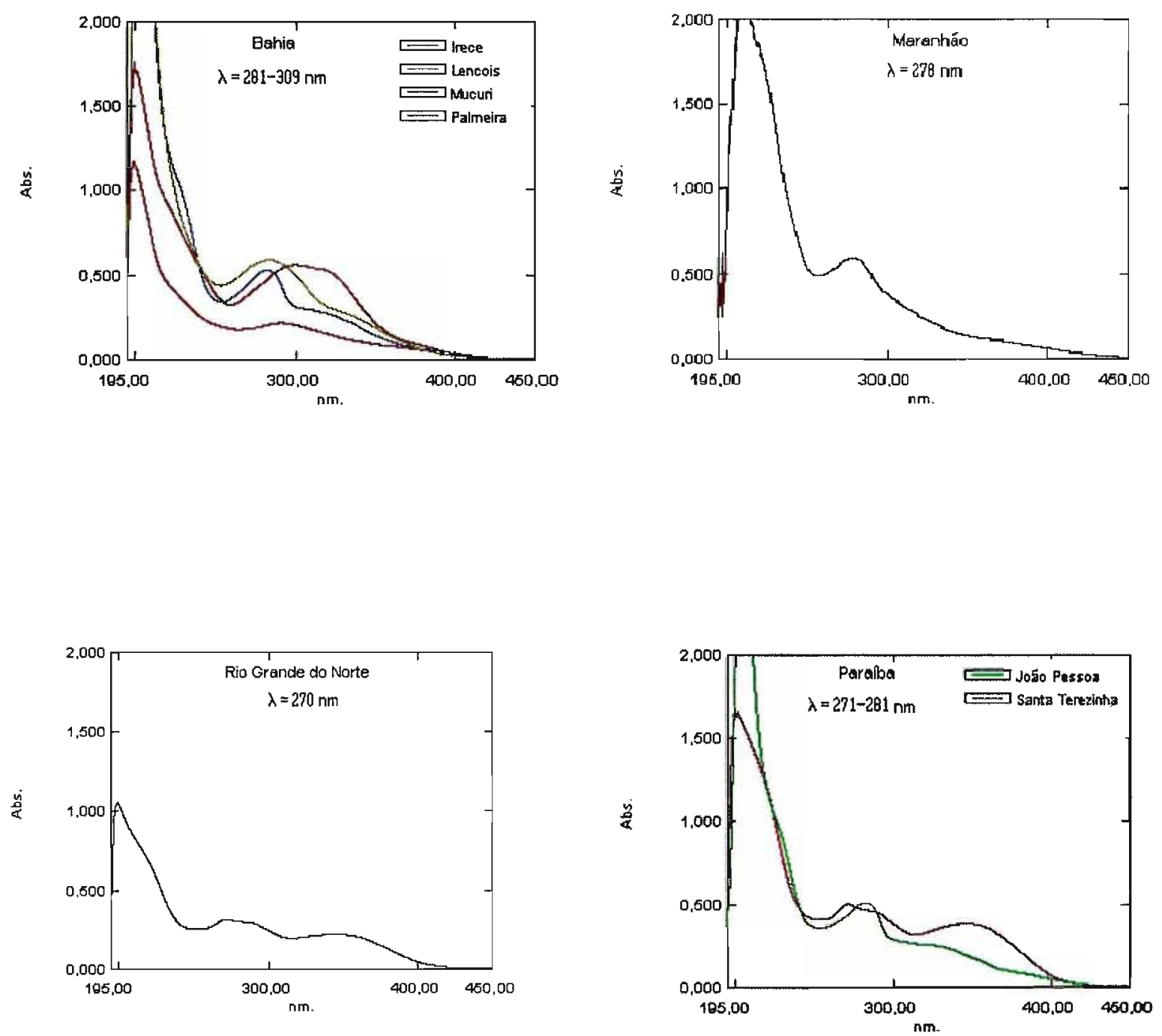

Figura 23: Espectros de Absorção na região UV-visível dos extratos etanólicos das amostras de própolis bruta da região nordeste. 

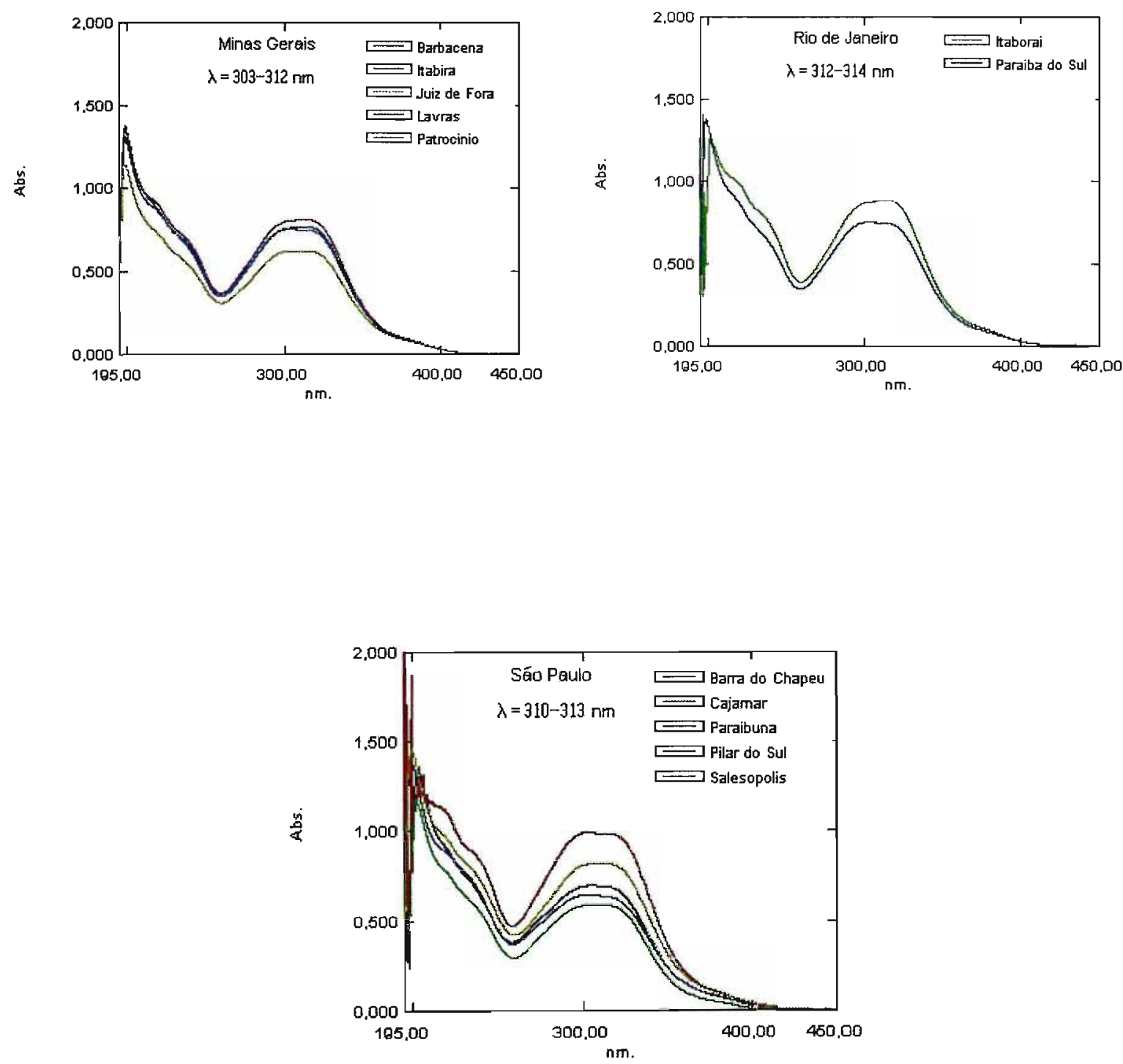

Figura 24: Espectros de Absorção na região UV-visível dos extratos etanólicos das amostras de própolis bruta da região sudeste. 

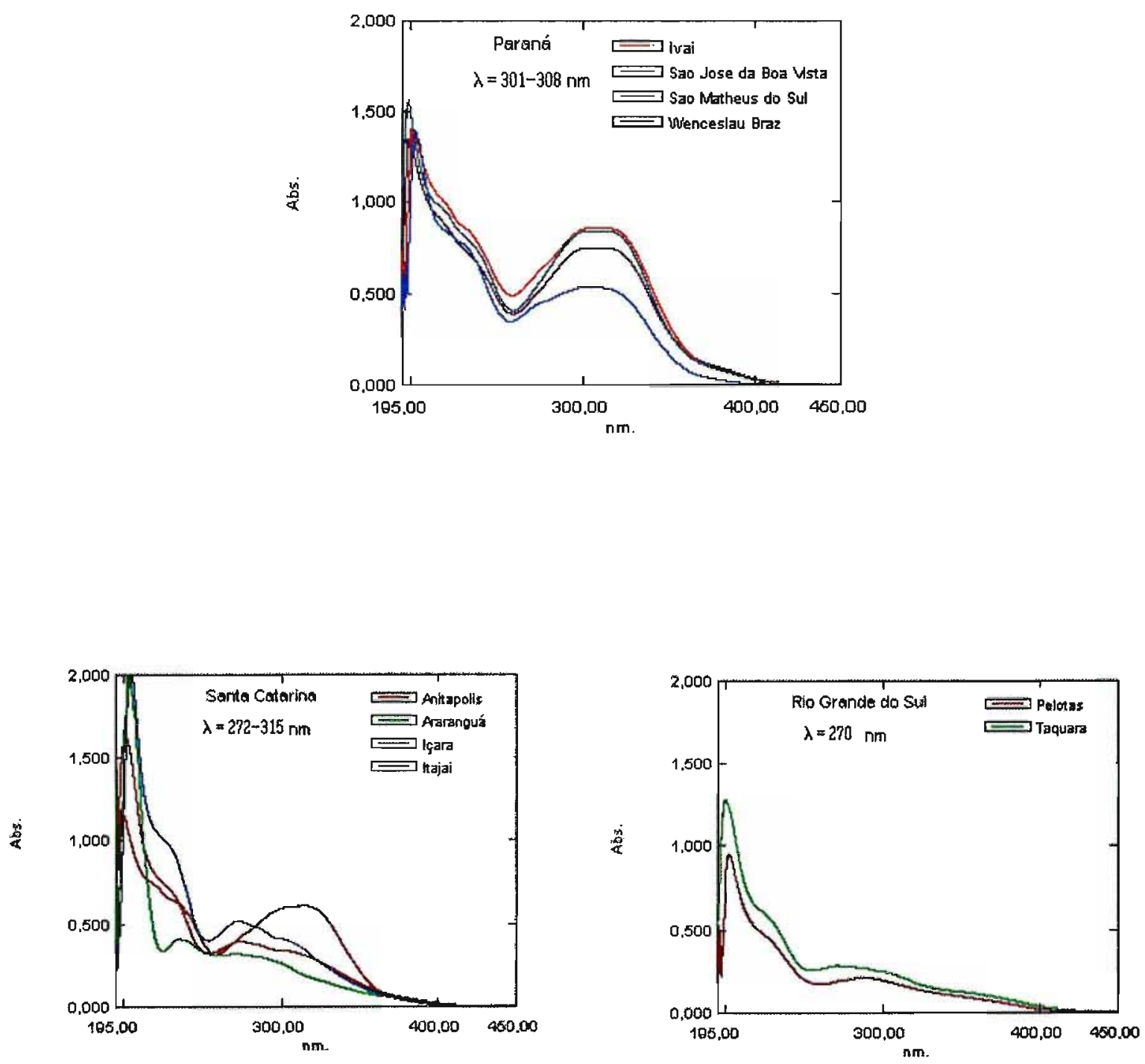

Figura 25: Espectros de Absorção na região UV-visível dos extratos etanólicos das amostras de própolis bruta da região sul. 


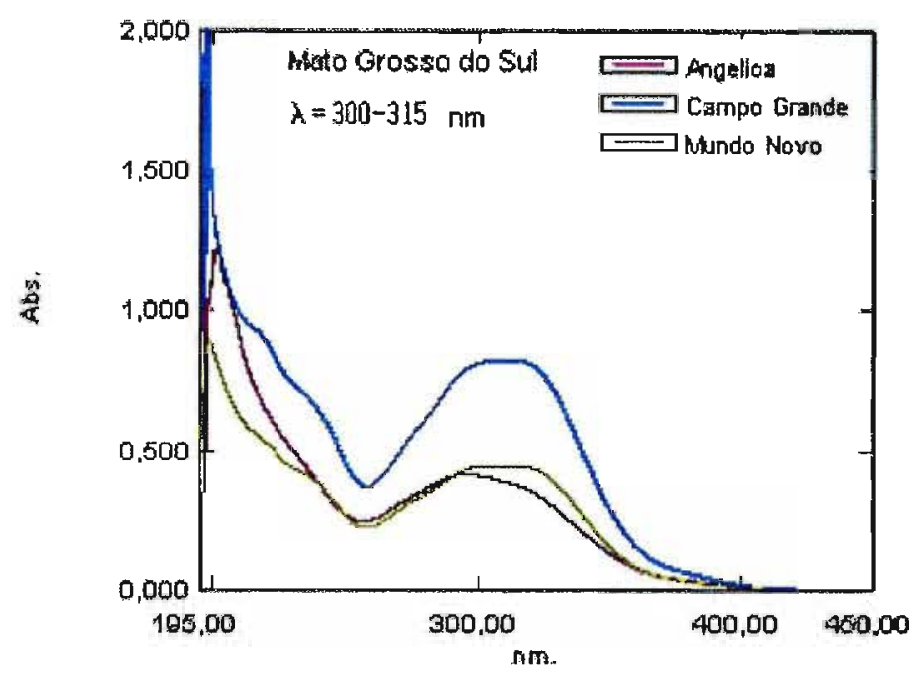

Figura 26: Espectros de Absorção na região UV-visível dos extratos etanólicos das amostras de própolis bruta da região centro-oeste.

\subsection{8 - Determinação de flavonóides totais com base em quercetina dos extratos etanólicos de própolis}

Os flavonóides podem ser utilizados como marcadores taxonômicos devido, a sua abundância relativa em quase todo o reino vegetal, especificidade em algumas espécies, relativa facilidade de identificação, relativa estabilidade e acúmulo com pouca influência do meio ambiente (ZUANAZZI, 1999).

A partir dos extratos etanólicos obtidos, segundo o procedimento descrito no item 4.1.4, foi determinado o teor de flavonóides totais utilizando-se como referência o padrão de quercetina e os resultados obtidos estão apresentados na Tabela 9.

A Figura 27, mostra a curva de calibração obtida utilizando-se soluções etanólicas de quercetina no intervalo de 0,01 a $0,2 \mathrm{mg} / \mathrm{mL}$. 


\section{Curva de Calibração - QUERCETINA}

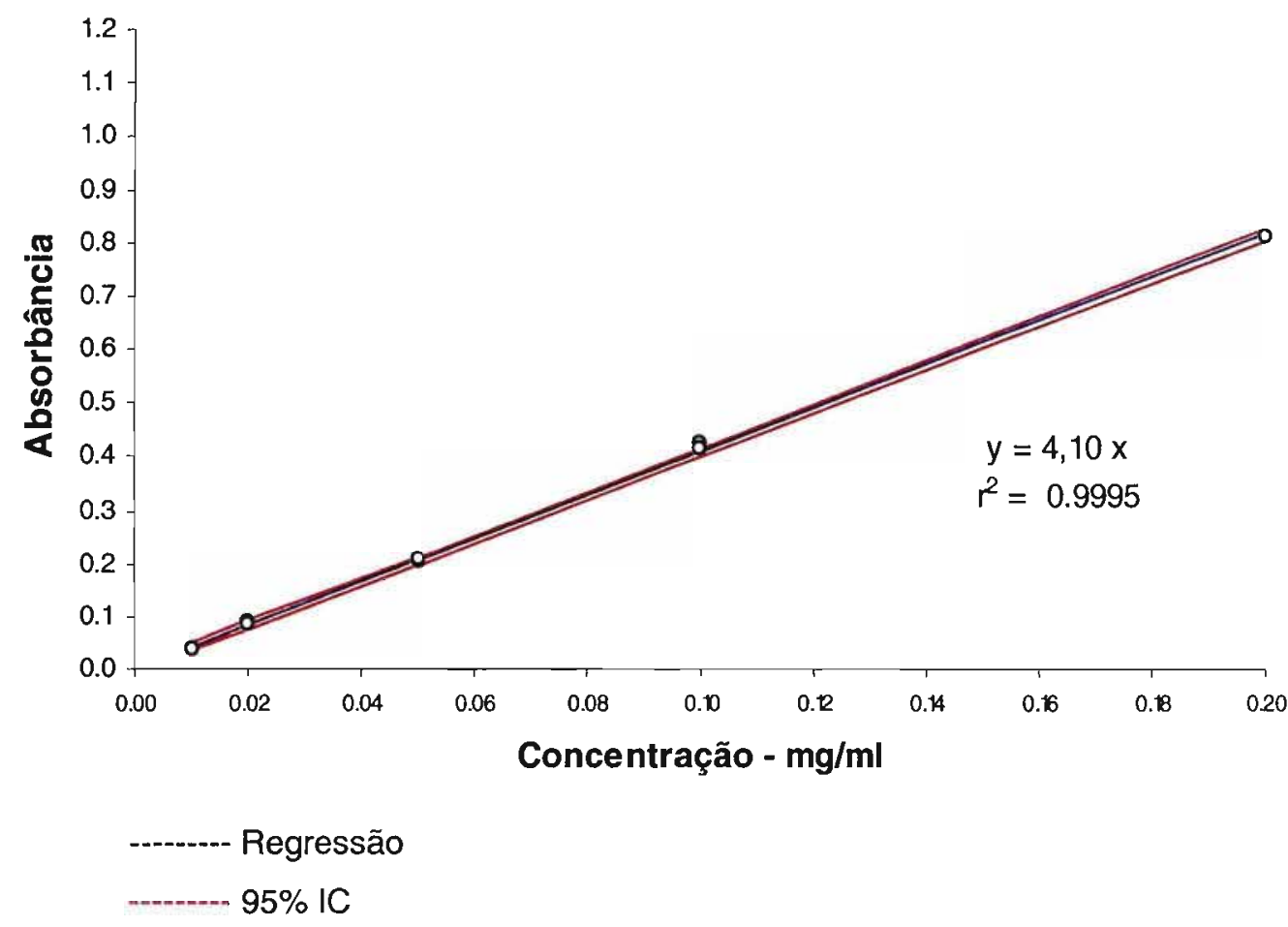

Figure 27 - Curva de calibração da quercetina com intervalo de confiança ao nível de $95 \%$.

A própolis para ter padrão de qualidade para comercialização, segundo a legislação brasileira, deve apresentar teor de flavonóides mínimo de 0,5\% $(\mathrm{m} / \mathrm{m})$ (BRASIL, 2001). 
Tabela 9 - Teor de flavonóides totais com base em quercetina dos extratos etanólico das amostras de própolis bruta.

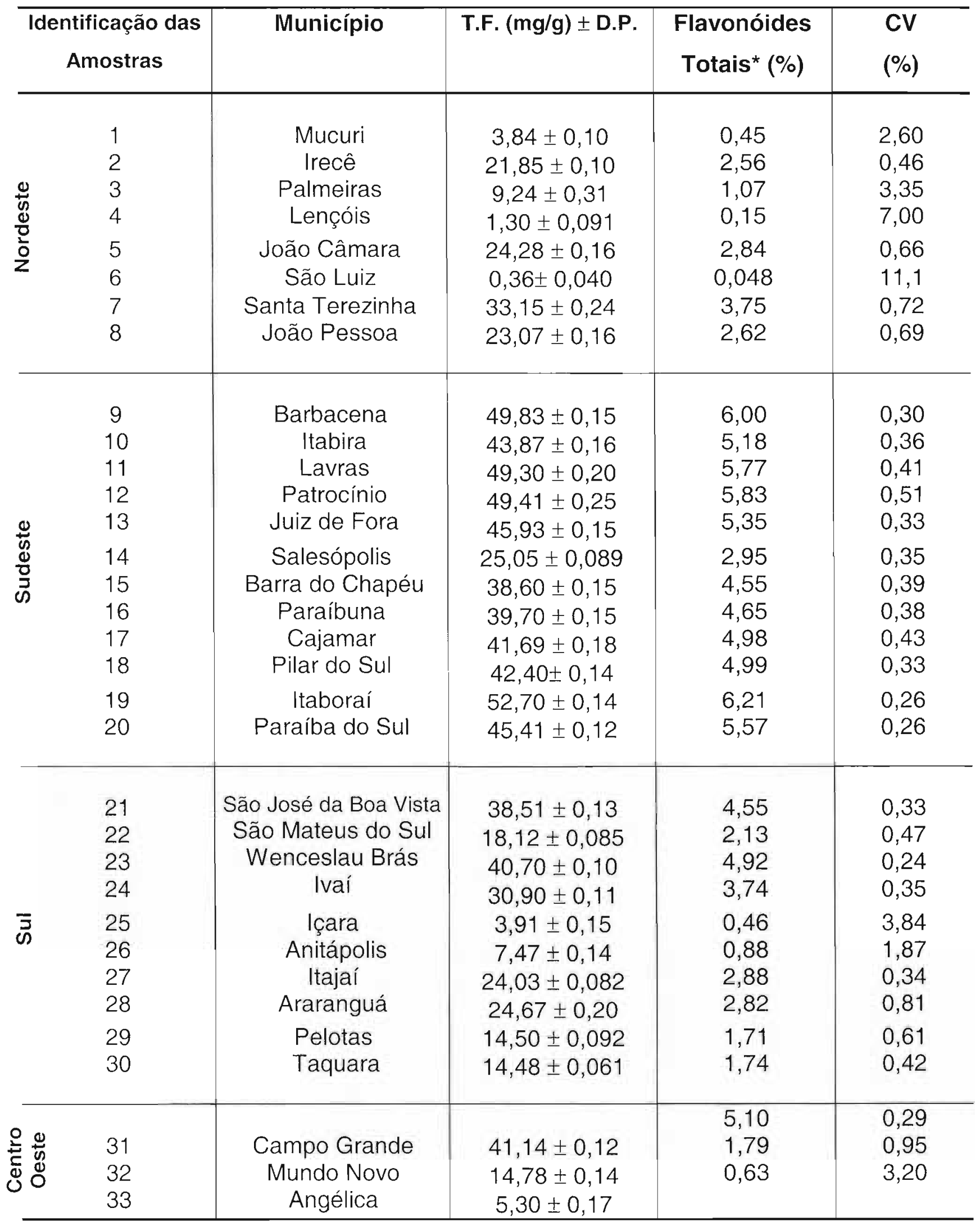

$\left.{ }^{*}\right)$ T.F: Teor de flavonóides.

$\left(^{* *}\right)$ Os valores acima representam média de três determinações. 
Como pode ser observado na Tabela 9, existe uma grande variação no teor de flavonóides totais presentes nas amostras de própolis, variando de 0,048 (São Luiz- Maranhão) a 6,21\% (Itaboraí - Rio de Janeiro).

Os teores de flavonóides da própolis de Içara - Santa Catarina $(0,46 \%)$, Mucuri - Bahia (0,45\%), São Luiz - Maranhão (0,048\%) e Lençóis - Bahia $(0,15 \%)$ estão abaixo do limite estabelecido pela legislação vigente. O método utilizado quantifica o teor de flavonóides com base em quercetina (flavonol), porém as amostras de própolis analisadas podem conter outros tipos de flavonóides.

As amostras obtidas na região Norte, Nordeste e Sul, com exceção das amostras do Paraná, apresentaram baixa concentração de flavonóides totais quando comparadas com as amostras obtidas na região Sudeste.

Bonvehi, Coll e Jordá (1994) analisaram o teor de flavonóides, pelo método de Folin-Ciocalteau, em própolis do Brasil encontrando valor médio de $3,0 \%$.

Woisky e Salatino (1998) e Mori (1997) avaliaram o teor de flavonóides em própolis do Estado de São Paulo encontrando valores na faixa de $0,77-2,69 \%$ e 0,67-1,19\%, respectivamente. Funari (2005) avaliou amostras provenientes da Serra do Japi - São Paulo encontrando valor médio de 2,64\%. A metodologia utilizada por estes autores foi o método espectrofotométrico baseado na reação de flavonóides com cloreto de alumínio.

Ikegaki (2001) e Bruschi (2002) avaliaram o teor de flavonóides em amostras de própolis da região Sul do Brasil. Ikegaki analisou amostras do Rio Grande do Sul e do Paraná obtendo valores que variaram entre 3,4 a 18,5 mg/g e 1,39 111,97 $\mathrm{mg} / \mathrm{g}$, respectivamente. Bruschi analisou amostras de Maringá obtendo um valor médio de $2,40 \%$.

Comparando-se os perfis especrofométrico das amostras de própolis 
estudadas com seus respectivos valores de flavonóides totais, pode-se inferir que existe, para algumas regiões, uma correlação entre os valores obtidos com os valores de absorção máxima do espectro de absorção, tal como foi observado no trabalho desenvolvido por Koo (1996). Para as amostras de própolis da Paraíba não foi observada esta correlação.

O resultado da análise estatística está apresentado na Figura 28.

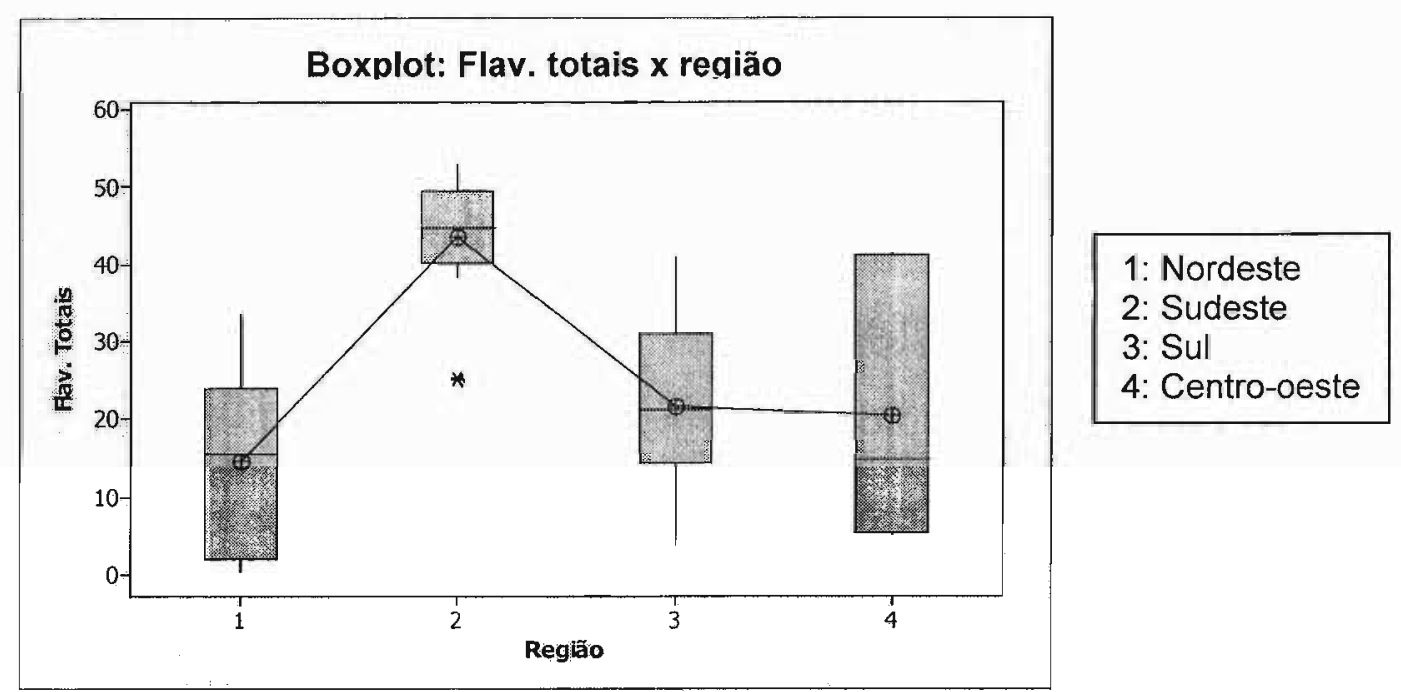

Figura 28: Gráfico da relação entre teores de flavonóides totais de amostras de própolis em função das diversas regiões brasileira.

Analisando a Figura 28 pode-se verificar que a região 2 (sudeste) foi a que apresentou uma menor dispersão e apresentou teor de flavonóides totais estatisticamente superior as demais regiões. Já a região 4 (centro-oeste) foi a que apresentou maior variabilidade nos ríveis de teor de flavonóides. A região 1 (Nordeste) apresentou níveis de teor de flavonóides estatisticamente semelhantes às regiões 3 e 4 .

Embora a própolis seja produzida pela mesma espécie de abelha (Apis mellifera), o teor de flavonóides sofre variação com a estação climática, localização 
geográfica e origem botânica (PARK et al, 1995, 1997; BANKOVA et al, 1998, 1999; BANKOVA; CASTRO; MARCUCCI, 2000; MARCUCCI et al, 1998; MARCUCCI; BANKOVA, 1999).

\subsection{9 - Determinação de compostos fenólico totais com base em ácido gálico dos extratos etanólicos de própolis}

Alguns compostos fenólicos são utilizados para estabelecer a qualidade da própolis são: ácido cumárico, ácido ferúlico, galangina, quercetina, canferol e, mais recentemente, o artepillin-C.

A partir dos extratos etanólicos obtidos, segundo o procedimento descrito no item 4.1.4, foi determinado o teor de compostos fenólicos totais utilizando-se como referência o padrão de ácido gálico e os resultados obtidos estão apresentados na Tabela 10.

A própolis para ter padrão de qualidade adequado para comercialização, segundo a legislação brasileira, deve apresentar teores de fenólicos de no mínimo $5,0 \%(\mathrm{~m} / \mathrm{m})$ (BRASIL, 2001) 
Tabela 10 - Teor de fenólicos totais com base em ácido gálico dos extratos etanólico das amostras de própolis bruta.

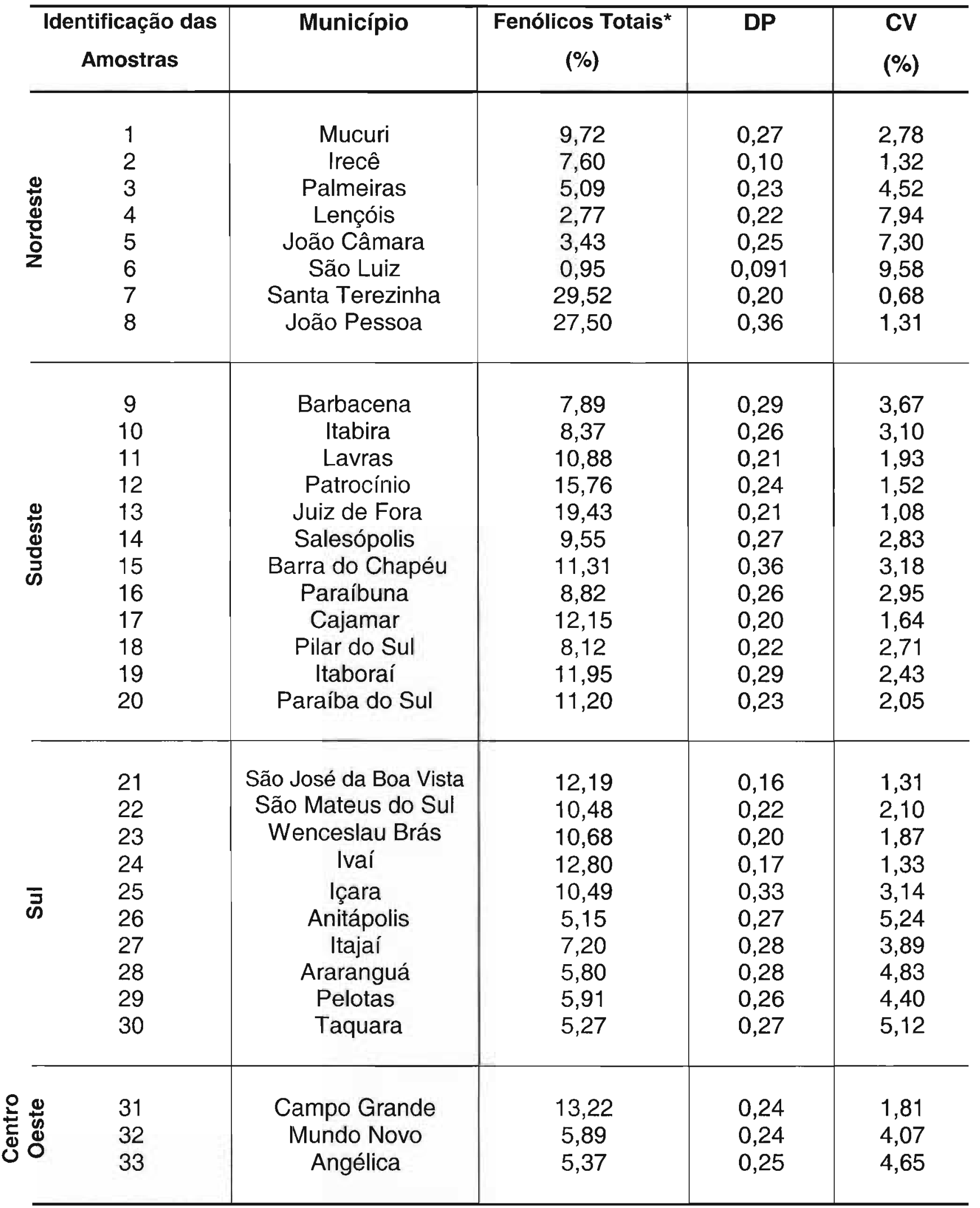

* Os valores acima representam média de três determinações. 
Como pode ser observado na Tabela 10, existe uma grande variação no teor de fenólicos totais presente nas amostras de própolis, variando de $0,95 \%$ em São Luiz a $29,52 \%$ em Santa Terezinha.

O teor de fenólicos totais da própolis de Lençóis - Bahia $(2,77 \%)$, João Câmara - Rio Grande do Norte (3,43\%), São Luiz - Maranhão $(0,95 \%)$ estão abaixo do limite estabelecido pela legislação vigente.

Woisky (1996) avaliou o teor de fenólicos totais utilizando o método de FolinDenis e Folin-Ciocalteau em própolis do estado de São Paulo encontrando valores na faixa de $7,05-9,29 \%$ e $9,63-13,72 \%$, respectivamente. O autor observou que o método de Folin-Denis apresentou um erro percentual maior que o método de FolinCiocalteau.

González et al (2003) analisaram o teor de fenólicos totais em amostras de própolis de Tucumán na Argentina utilizando três métodos colorimétricos distintos. Os autores observaram que o método de Folin-Ciocalteau apresentou maior sensibilidade e reprodutibilidade em comparação aos outros dois métodos.

Dos resultados da literatura, os valores para o teor de fenólicos totais que mais se aproximaram dos obtidos neste trabalho foram os de Cunha et al (2004) e Funari (2005). Cunha et al utilizaram amostras de própolis provenientes de Sorocaba - São Paulo (8,53\%), enquanto que Funari avaliou amostras da Serra do Japi - São Paulo, encontrando valor médio de 7,39\%.

O resultado da análise estatística está apresentado na Figura 29. 


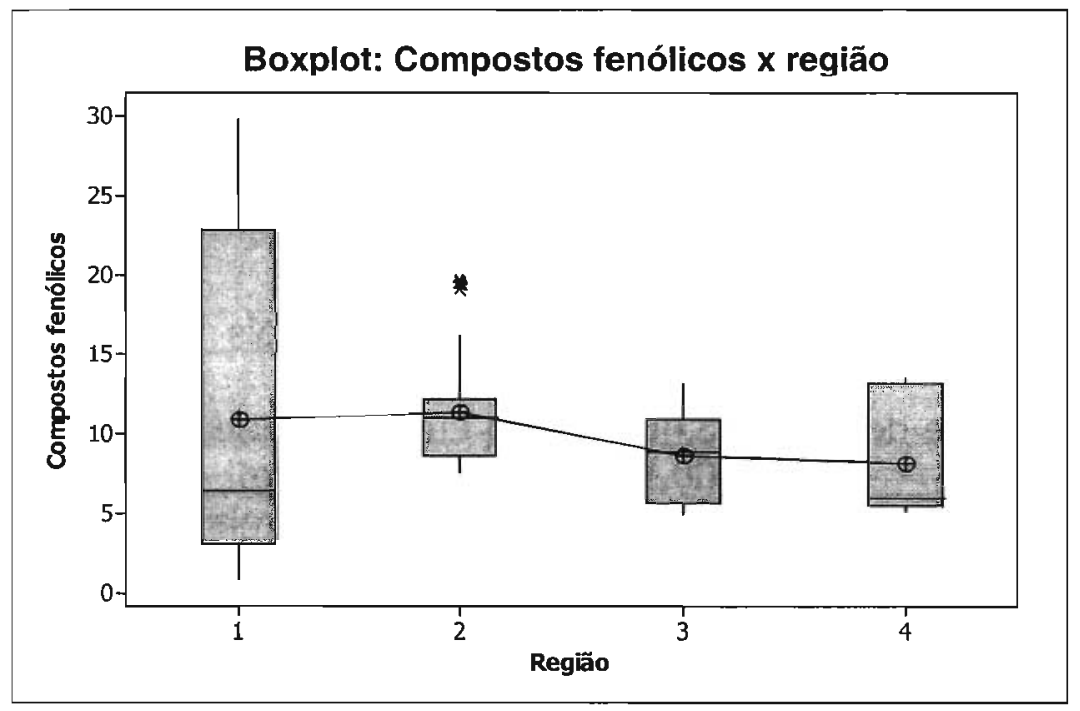

1: Nordeste

2: Sudeste

3: Sul

4: Centro-oeste

Figura 29: Gráfico da relação entre teores de fenólicos totais de amostras de própolis em função das diversas regiões brasileiras.

Analisando a Figura 29 pode-se verificar que a região 1 (nordeste) foi a que apresentou uma maior dispersão. Através do teste de Mood pode-se verificar que as quatro regiões apresentaram a mediana dos níveis de fenólicos totais estatisticamente iguais, valor- $p=0,092$.

\subsection{Determinação da atividade antioxidante}

Antioxidante se refere a qualquer substância que, quando presente em baixas concentrações em relação ao substrato oxidável, retarda ou inibe consideravelmente a oxidação do substrato (THOMAS, 2000).

A atividade antioxidante dos extratos metanólicos de própolis foi determinada de acordo com o método descrito no item 4.2.2. O principio deste método baseia-se na descoloração (oxidação) do caroteno induzido pelos produtos da degradação oxidativa de um ácido graxo, no caso o ácido linoléico, que foi acompanhada através de um ensaio espectrofotométrico. A manutenção da cor alaranjada do $\beta$-caroteno 
foi acompanhada em espectrofotômetro utilizando-se tubos testes contendo os respectivos extratos.

Na Tabela 11, estão apresentados os resultados da atividade antioxidante dos extratos de própolis em estudo no sistema $\beta$-caroteno/ácido linoléico.

Tabela 11 - Atividade antioxidante dos extratos metanólico das amostras de própolis bruta.

\begin{tabular}{|c|c|c|c|c|}
\hline & $\begin{array}{c}\text { Identificação das } \\
\text { Amostras }\end{array}$ & Município & $\begin{array}{c}\text { Atividade antioxidante } \\
\qquad(\%) \\
\text { BHT - 100ppm * }\end{array}$ & $\begin{array}{c}\text { Atividade } \\
\text { antioxidante } \pm \mathrm{DP}(\%) \\
\text { Extratos - 100ppm * }\end{array}$ \\
\hline & $\begin{array}{l}1 \\
2 \\
3 \\
4 \\
5 \\
6 \\
7 \\
8\end{array}$ & $\begin{array}{c}\text { Mucuri } \\
\text { Irecê } \\
\text { Palmeiras } \\
\text { Lençóis } \\
\text { João Câmara } \\
\text { São Luiz } \\
\text { Santa Terezinha } \\
\text { João Pessoa }\end{array}$ & $\begin{array}{l}85,71 \\
85,66 \\
85,52 \\
85,52 \\
85,33 \\
86.24 \\
85,52 \\
85,52\end{array}$ & $\begin{array}{l}90,28 \pm 0,48 \\
77,02 \pm 0,45 \\
80,33 \pm 0,58 \\
69,74 \pm 0,48 \\
57,85 \pm 0,43 \\
51,33 \pm 0,49 \\
91,61 \pm 0,43 \\
92,70 \pm 0,37\end{array}$ \\
\hline & $\begin{array}{c}9 \\
10 \\
11 \\
12 \\
13 \\
14 \\
15 \\
16 \\
17 \\
18 \\
19 \\
20\end{array}$ & $\begin{array}{c}\text { Barbacena } \\
\text { Itabira } \\
\text { Lavras } \\
\text { Patrocínio } \\
\text { Juiz de Fora } \\
\text { Salesópolis } \\
\text { Barra do Chapéu } \\
\text { Paraíbuna } \\
\text { Cajamar } \\
\text { Pilar do Sul } \\
\text { Itaboraí } \\
\text { Paraíba do Sul }\end{array}$ & $\begin{array}{l}85,33 \\
85,71 \\
85,66 \\
85,71 \\
85,71 \\
85,33 \\
85,33 \\
85,33 \\
85,66 \\
85,66 \\
85,71 \\
85,71\end{array}$ & $\begin{array}{l}83,73 \pm 0,45 \\
88,40 \pm 0,55 \\
90,55 \pm 0,54 \\
89,48 \pm 0,49 \\
89,40 \pm 0,52 \\
86,59 \pm 0,55 \\
88,46 \pm 0,65 \\
83,67 \pm 0,65 \\
88,58 \pm 0,58 \\
86,97 \pm 0,60 \\
90,35 \pm 0,80 \\
88,38 \pm 0,78\end{array}$ \\
\hline$\overline{\bar{n}}$ & $\begin{array}{l}21 \\
22 \\
23 \\
24 \\
25 \\
26 \\
27 \\
28 \\
29 \\
30 \\
\end{array}$ & $\begin{array}{c}\text { São José da Boa Vista } \\
\text { São Mateus do Sul } \\
\text { Wenceslau Brás } \\
\text { Ivaí } \\
\text { Içara } \\
\text { Anitápolis } \\
\text { Itajaí } \\
\text { Araranguá } \\
\text { Pelotas } \\
\text { Taquara } \\
\end{array}$ & $\begin{array}{l}85,33 \\
85,66 \\
85,33 \\
85,71 \\
85,52 \\
85,33 \\
85,52 \\
85,52 \\
85,71 \\
85,71 \\
\end{array}$ & $\begin{array}{l}70,43 \pm 0,76 \\
85,64 \pm 0,54 \\
78,20 \pm 0,71 \\
81,70 \pm 0,75 \\
84,83 \pm 0,50 \\
65,92 \pm 0,53 \\
88,55 \pm 0,76 \\
76,57 \pm 0,53 \\
71,43 \pm 0,66 \\
74,67 \pm 0,61 \\
\end{array}$ \\
\hline & $\begin{array}{l}31 \\
32 \\
33\end{array}$ & $\begin{array}{c}\text { Campo Grande } \\
\text { Mundo Novo } \\
\text { Angélica }\end{array}$ & $\begin{array}{l}85,33 \\
85,52 \\
85,52\end{array}$ & $\begin{array}{l}86,52 \pm 0,58 \\
86,38 \pm 0,75 \\
76,24 \pm 0,66\end{array}$ \\
\hline
\end{tabular}

$\left(^{*}\right)$ Os valores acima representam média de três determinações.

$\mathrm{DP}=$ desvio padrão. 
De acordo com os resultados obtidos, verificou-se que a maioria das amostras apresentaram alta atividade antioxidante, variando na faixa entre 85,64 a $92,70 \%$, após 3 (três) horas de reação.

Aga et al (1994), Basnet, Matsuno e Neidlein (1997) isolaram compostos com característica antioxidante da própolis brasileira (provenientes de Minas Gerais) conhecidos como Artepillin-C e propol, respectivamente.

Ikegaki (2001) avaliou a atividade antioxidante em própolis da região Sul do Brasil encontrando valores na faixa de $65,5-95,1 \%$, sendo superior ao valor reportado no presente trabalho.

Kumazawa et al (2004) avaliaram a atividade antioxidante em própolis de diversos países utilizando o método do $\beta$-caroteno/ácido linoleico e do DPPH, sendo considerado como alta atividade, valores superiores a $60 \%$. No mesmo trabalho, amostras de própolis da China, Argentina, Chile e Hungria apresentaram valores na faixa entre 70 a $78 \%$.

O resultado da análise estatística está apresentado na Figura 30.

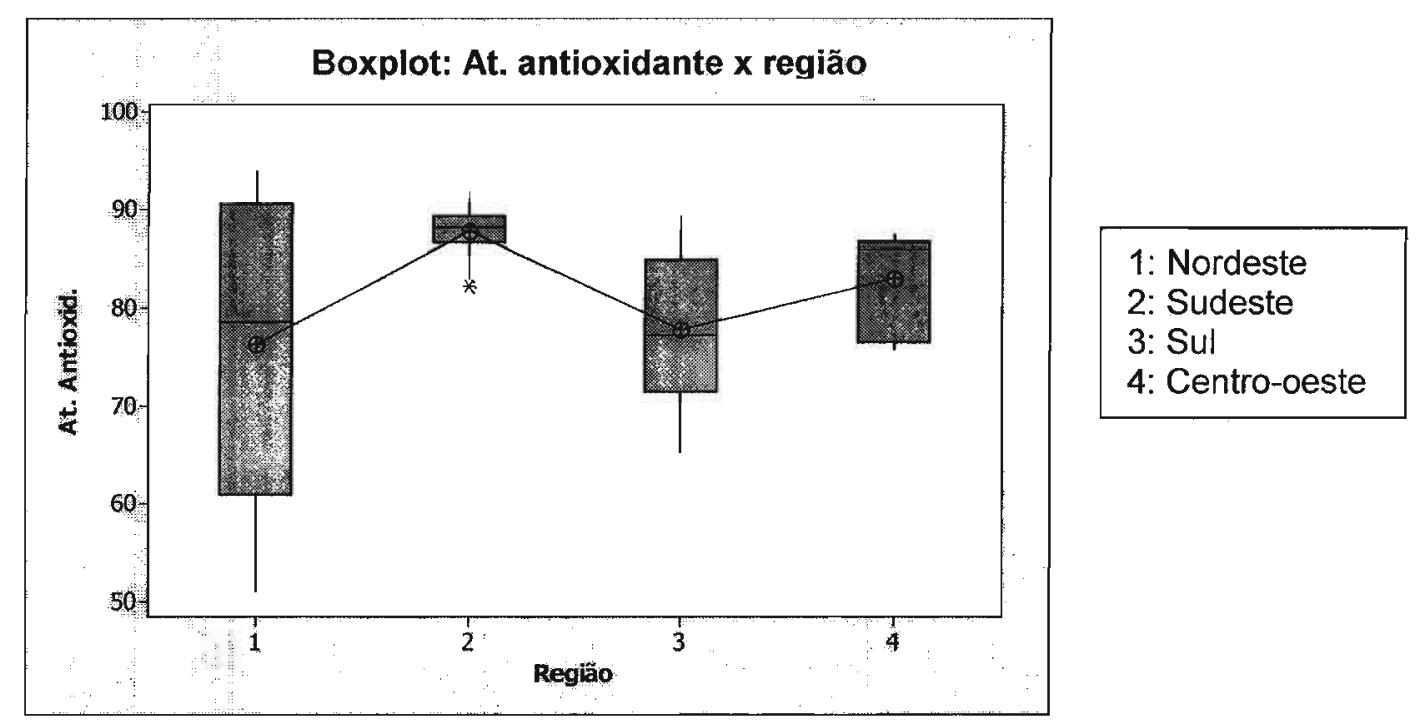

Figura 30: Gráfico da relação entre a atividade antioxidante de amostras de própolis em função das diversas regiōes brasileiras. 
Analisando a Figura 30 pode-se observar que as regiões 1 (nordeste) e 2 (sudeste) apresentaram maior e menor variabilidade nos niveis de atividade antioxidante, respectivamente.

Através do teste de Mood pode-se verificar que as quatro regiões não apresentaram a mediana dos niveis de atividade antioxidante estatisticamente iguais, valor-p=0,000. A região 2 apresentou mediana dos niveis de atividade antioxidante superior e estatisticamente diferente das regiões 3 (sul) e 4 (centrooeste), sendo estas duas regiões estatisticamente semelhantes.

\subsection{Análise polínica}

A identificação de táxons vegetais através da morfologia de seus grãos de pólen permite a inferência, através de associações polínicas, sobre o tipo de vegetação de onde foi coletada a própolis (D'ALBORE, 1979).

Os grãos de pólen encontrados na própolis são levados para o interior da colméia por diferentes vias: durante a coleta de néctar, pólen ou resinas, como também aderidos ao corpo das abelhas ou pelo vento. A quantidade de pólen presente na própolis depende do clima, da vegetação e da região na qual a própolis foi coletada (BARTH et al, 1999).

Segundo Barth et al (1999) e D’Albore (1979), as análises qualitativas e quantitativas dos tipos polínicos encontrados em amostras de própolis são instrumentos utilizáveis para a caracterização geográfica de sua procedência, bem como da origem florística.

Deve-se considerar que muitos compostos presentes na própolis podem advir de fontes botânicas que não a originaram, como por exemplo, constituintes de pólens contaminantes e carboidratos agregados durante a manipulação pelas 
abelhas (TEIXEIRA et al, 2003).

A metodologia utilizada para análise polínica foi qualitativa, sendo possível apenas identificar grãos de pólen mais freqüentes.

O resultado da análise polínica das amostras de própolis pode ser observado na Tabela 12.

Tabela 12 - Análise polínica das amostras de própolis após extração alcoólica, tratamento com $\mathrm{KOH}$ e acetólise.

(Continua)

\begin{tabular}{|c|c|c|c|c|}
\hline Origem & Munícipio & $\begin{array}{c}\text { Grãos de } \\
\text { pólen }\end{array}$ & $\begin{array}{c}\text { Pólen mais freqüente } \\
\text { (Familia) }\end{array}$ & Nome Vulgar \\
\hline BA & $\begin{array}{c}\text { Irecê } \\
\text { Palmeiras } \\
\text { Lençóis }\end{array}$ & $\begin{array}{c}+++ \\
+ \\
++\end{array}$ & $\begin{array}{c}\text { Solanaceae, Borreria } \\
\text { verticillata, Arecaceae, } \\
\text { Sapindaceae } \\
\text { Mimosa verrucosa } \\
\text { Mimosa } \\
\text { Arecaceae }\end{array}$ & $\begin{array}{l}\text { Plantas selvagens } \\
\text { vassourinha } \\
\text { Palmeira } \\
\text { Cipó } \\
\text { Espinheiro preto } \\
\text { Espinheiro } \\
\text { Palmeira }\end{array}$ \\
\hline PB & $\begin{array}{l}\text { S. Terezinha } \\
\text { João Pessoa }\end{array}$ & $\begin{array}{c}++++ \\
++\end{array}$ & $\begin{array}{c}\text { Sem pólen dominante } \\
\text { ou acessório } \\
\text { Eucalyptus }\end{array}$ & Eucalipto \\
\hline $\mathrm{RN}$ & João Câmara & $(+)$ & $\begin{array}{c}\text { Sem pólen dominante } \\
\text { ou acessório }\end{array}$ & ------------------ \\
\hline MG & $\begin{array}{l}\text { Barbacena } \\
\text { Itabira } \\
\text { Lavras } \\
\text { Patrocínio } \\
\text { Juiz de Fora }\end{array}$ & $\begin{array}{l}++ \\
+ \\
++ \\
++ \\
++\end{array}$ & $\begin{array}{c}\text { Eucalyptus } \\
\text { Asteraceae } \\
\text { Sem pólen dominante } \\
\text { ou acessório } \\
\text { Eucalyptus, } \\
\text { Asteraceae } \\
\text { Eucalyptus, } \\
\text { Asteraceae }\end{array}$ & $\begin{array}{c}\text { Eucalipto } \\
\text { Alecrim, girassol } \\
-9-- \\
\text { Eucalipto } \\
\text { Alecrim } \\
\text { Eucalipto } \\
\text { Alecrim }\end{array}$ \\
\hline SP & $\begin{array}{l}\text { Salesópolis } \\
\text { B. do Chapéu } \\
\text { Paraíbuna } \\
\text { Cajamar } \\
\text { Pilar do Sul }\end{array}$ & $\begin{array}{l}+ \\
+ \\
++ \\
++ \\
++\end{array}$ & $\begin{array}{c}\text { Eucalyptus } \\
\text { Asteraceae } \\
\text { Asteraceae, } \\
\text { Solanaceae } \\
\text { Eucalyptus } \\
\text { Eucalyptus } \\
\text { Eucalyptus, Asteraceae }\end{array}$ & $\begin{array}{c}\text { Eucalipto } \\
\text { Margarida, alecrim } \\
\text { Margarida,alecrim } \\
\text { Plantas selvagens } \\
\text { Eucalipto } \\
\text { Eucalipto } \\
\text { Eucalipto, alecrim }\end{array}$ \\
\hline
\end{tabular}

$(+)=$ muito raro; $+=$ raro; ++ = pouco; +++ = médio; ++++ = muito

$\mathrm{BA}=$ Bahia/ RN=Rio Grande do Norte/ $\mathrm{MG}=$ Minas Gerais/ SP=São Paulo/ RJ=Rio de Janeiro

$\mathrm{PR}=$ Paraná/SC=Santa Catarina/RS=Rio Grande do Sul/MT=Mato Grosso

Pólen dominante $=$ freqüência maior que $45 \%$

Pólen acessório= freqüência entre 15 a 45\%. 
Tabela 12 - Análise polínica das amostras de própolis após extração alcoólica, tratamento com $\mathrm{KOH}$ e acetólise.

(Conclusão)

\begin{tabular}{|c|c|c|c|c|}
\hline Origem & Munícipio & $\begin{array}{l}\text { Grãos de } \\
\text { pólen }\end{array}$ & $\begin{array}{l}\text { Pólen mais freqüente } \\
\text { (Família) }\end{array}$ & Nome Vulgar \\
\hline RJ & $\begin{array}{l}\text { Itaboraí } \\
\text { Paraíba do } \\
\text { Sul }\end{array}$ & $\begin{array}{l}(+) \\
(+)\end{array}$ & $\begin{array}{l}\text { Sem pólen dominante } \\
\text { ou acessório } \\
\text { Sem pólen dominante } \\
\text { ou acessório }\end{array}$ & ------------------- \\
\hline PR & $\begin{array}{l}\text { S. J.B Vista } \\
\text { S. Mateus Sul } \\
\text { Wenc. Bras } \\
\text { Ivaí }\end{array}$ & $\begin{array}{l}++ \\
+ \\
+ \\
++\end{array}$ & $\begin{array}{l}\text { Sem pólen dominante } \\
\text { ou acessório } \\
\text { Asteraceae } \\
\text { Sem pólen dominante } \\
\text { ou acessório } \\
\text { Asteraceae }\end{array}$ & $\begin{array}{c}\text { Margarida, alecrim } \\
\text { Margarida, alecrim }\end{array}$ \\
\hline SC & $\begin{array}{c}\text { Içara } \\
\text { Anitápolis } \\
\text { Itajaí } \\
\text { Araranguá }\end{array}$ & $\begin{array}{c}++++ \\
++++ \\
++ \\
++\end{array}$ & $\begin{array}{c}\text { Eucalyptus } \\
\text { Eucalyptus } \\
\text { Eucalyptus } \\
\text { Sem pólen dominante } \\
\text { ou acessório }\end{array}$ & $\begin{array}{l}\text { Eucalipto } \\
\text { Eucalipto } \\
\text { Eucalipto }\end{array}$ \\
\hline RS & $\begin{array}{l}\text { Pelotas } \\
\text { Taquara }\end{array}$ & $\begin{array}{l}+++ \\
+++\end{array}$ & $\begin{array}{c}\text { Sem pólen dominante } \\
\text { ou acessório } \\
\text { Eucalyptus, } \\
\text { Asteraceae }\end{array}$ & $\begin{array}{c}\text { Eucalipto } \\
\text { Margarida, girassol }\end{array}$ \\
\hline MT & $\begin{array}{l}\text { C. Grande } \\
\text { Mundo Novo } \\
\text { Angélica }\end{array}$ & $\begin{array}{l}(+) \\
(+) \\
(+)\end{array}$ & $\begin{array}{l}\text { Sem pólen dominante } \\
\text { ou acessório } \\
\text { Sem pólen dominante } \\
\text { ou acessório } \\
\text { Sem pólen dominante } \\
\text { ou acessório }\end{array}$ & \\
\hline
\end{tabular}

$(+)$ = muito raro; + = raro; ++ = pouco; +++ = médio; ++++ = muito

$\mathrm{BA}=$ Bahia/ RN=Rio Grande do Norte/ $\mathrm{MG}=$ Minas Gerais/ SP=São Paulo/ RJ=Rio de Janeiro

$\mathrm{PR}=$ Paraná/SC=Santa Catarina/ RS=Rio Grande do Sul/ MT=Mato Grosso

Pólen dominante= freqüência maior que $45 \%$

Pólen acessório= freqüência entre 15 a $45 \%$.

D`Albore (1979) avaliou amostras de própolis de vários países e estabeleceu através do reconhecimento dos grãos de pólen, a origem geográfica de própolis provenientes da Suíça, França, Itália, Alemanha, Escócia, Finlândia, Israel, Marrocos, Japão, Peru, Argentina, Cuba, Zâmbia, Austrália, Tanzânia, Canadá e Brasil. 
Barth (1998) estudou grãos de pólen em amostras de própolis brasileira, constatando os tipos Eucalyptus, Eupatorium e Mimosa caesalpinaefolia, como dominante nos espectros polínicos das amostras coletadas no Estado do Rio de Janeiro e Minas Gerais.

Bastos (2001) analisou o espectro polínico e os fragmentos de epiderme, tricomas tectores e tricomas glandulares em amostras de própolis do estado de Minas Gerais encontrando com maior freqüência grãos de pólen representados pelos tipos Baccharis, Vernonia, Eucalyptus, Astronium e Hyptis.

Barth et al. (2005) analisaram grãos de pólen em amostras de própolis vermelha provenientes da região Nordeste (Alagoas e Bahia) apresentando com maior freqüência os grão de pólen do tipo Mimosa, Palmeira (Arecaceae), Borreria densiflora, Borreria latifólia e Borreria verticillata (Rubiaceae), Myrcia (Myrtacea) e Schinus aff. Terebinthifolius (Anacardiaceae). Resultados semelhantes foram encontrados no presente trabalho para amostras de própolis provenientes da Bahia.

\section{4 - Validação da metodologia de determinação de artepillin-C}

Os conceitos, os objetivos e a metodologia da validação de um procedimento analítico são descritos pela Internacional Conference on Harmonisation of Technical Requeriments for Registration of Pharmaceutical for Human Use (ICH). Na análise de matrizes complexas, como a própolis, o tipo de método e o seu respectivo uso determinam quais parâmetros devem ser avaliados (DE SOUZA et al, 2002).

A validação de um método analítico pode ser definida como um processo formal, com o objetivo de se obter documentação e análise de dados, os quais permitem tanto descrever de forma detalhada o método, assim como identificar e controlar fatores de variação. O objetivo da validação deve estar claramente 
esclarecido, pois ele norteará as características a serem avaliadas (WOOD, 1999). As características de validação as quais devem ser consideradas são a exatidão, a precisão, o limite de detecção, o limite de quantificação, a linearidade e a variação (ICH Q2b, 2004).

O rigor na avaliação dos resultados e no estabelecimento dos limites de confiança depende da complexidade do método, da precisão e da sensibilidade dos instrumentos, da composição de homogeneidade das amostras e das exigências analíticas incidentes. De modo geral, quanto menor o número de etapas que constituem o método e quanto maior for a homogeneidade e uniformidade da amostra analisada, menor será o erro inerente acumulado (WOOD, 1999).

\subsection{1- Linearidade}

A linearidade do método de quantificação do teor de artepillin-C em própolis por cromatografia líquida de alta eficiência (CLAE) foi determinada analisando-se o artepillin-C, que apresentou tempo de retenção de 15 minutos.

O artepillin-C foi estudado em sete níveis de concentração de $(0,05-$ $15 \mu \mathrm{g} / \mathrm{mL}$ ), sendo a curva linear na faixa de $0,05-10 \mu \mathrm{g} / \mathrm{mL}$, como pode ser visualizado na Figura 31.

A equação linear foi $y=28758 x-356\left(r^{2}=0,9979\right)$ e o desvio padrão relativo da inclinação foi de $7,0 \%$. 


\section{Curva de Calibração - Arte pillin-C}

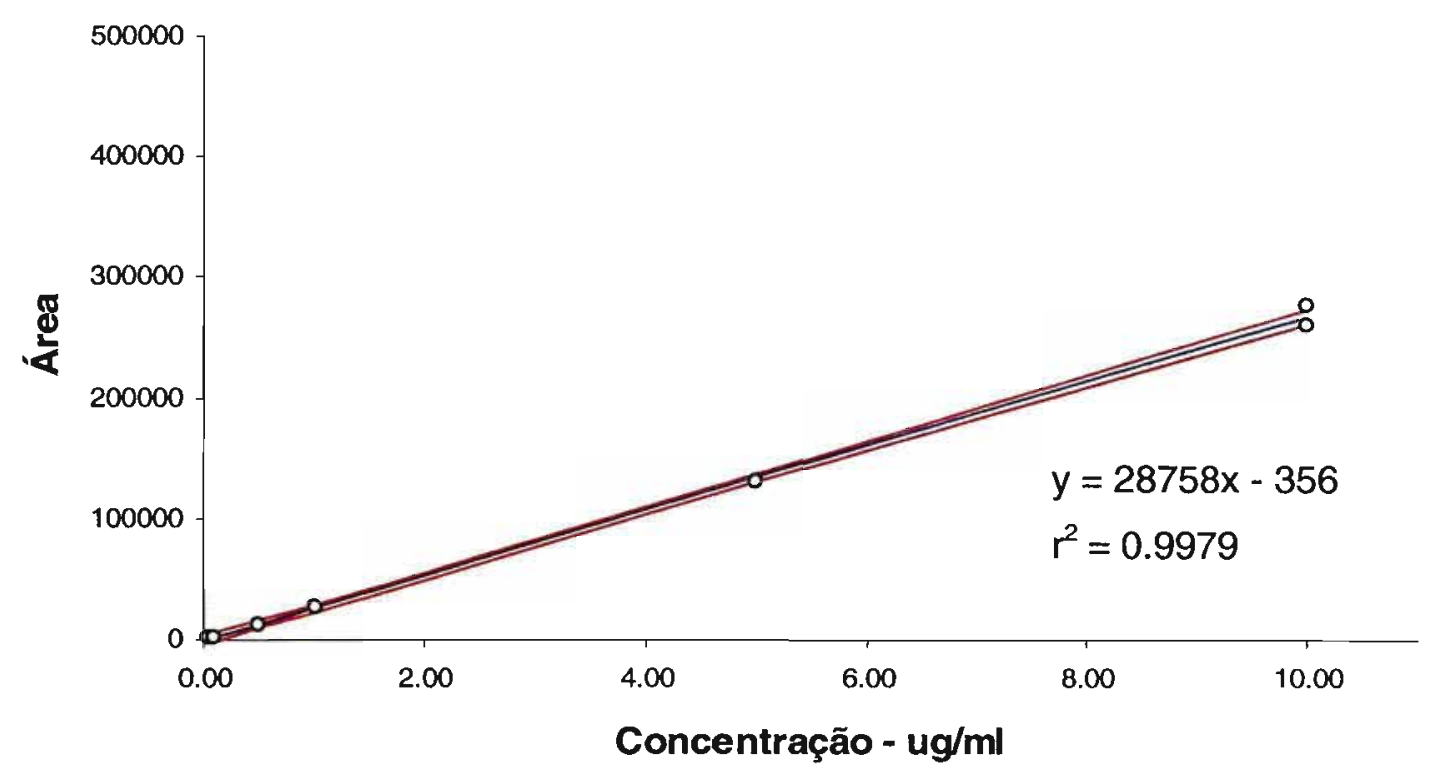

Regressão

$95 \%$ IC

Figure 31 - Curva de calibração do Artepillin-C pelo método cromatográfico com intervalo de confiança ao nível de $95 \%$.

\subsection{2- Limite de detecção e de quantificação}

O limite de detecção (LD), expresso como a menor concentração absoluta da substância na amostra que pode ser detectada, mas não necessariamente quantificada, foi de $0,0036 \mu \mathrm{g} / \mathrm{mL}$. A menor quantidade de artepillin-C na amostra que pode ser quantitativamente determinada com precisão e exatidão, sob condições experimentais estabelecidas, ou seja, seu limite de quantificação (LQ), foi de $0,012 \mu \mathrm{g} / \mathrm{mL}$.

O desvio padrão relativo ou coeficiente de variação percentual para as concentrações de Artepillin-C analisadas demonstraram repetibilidade (Tabela 13). 
Tabela 13 - Coeficiente de variação percentual (desvio padrão relativo) das concentrações de Artepillin-C analisadas

\begin{tabular}{l|c|c|c|c|c|c}
\hline $\begin{array}{l}\text { Concentração de Artepillin-C } \\
(\mu \mathrm{g} / \mathrm{mL}))^{*}\end{array}$ & $\mathbf{0 , 0 5}$ & $\mathbf{0 , 1}$ & $\mathbf{0 , 5}$ & $\mathbf{1 , 0}$ & $\mathbf{5 , 0}$ & $\mathbf{1 0 , 0}$ \\
\hline Coeficiente de variação (\%) & 5,40 & 5,25 & 2,79 & 2,60 & 2,35 & 1,21 \\
\hline
\end{tabular}

(*) Os valores acima representam média de cinco determinações.

\subsection{3- Precisão}

Para medir a precisão do método foi determinado o teor de artepillin- $\mathrm{C}$, seis vezes, em uma amostra de própolis originária da região de Minas Gerais, de concentração conhecida desse composto. Esta medida foi realizada em condições de repetitividade, ou seja, usando a mesma amostra, o mesmo reagente, no mesmo laboratório, com o mesmo equipamento e pelo mesmo operador em um curto intervalo de tempo. A precisão foi expressa em função do desvio padrão (DP) e do coeficiente de variação (CV), conforme Tabela 14.

Tabela 14 - Precisão do método analítico para determinação de Artepillin-C em própolis bruta, expressa pelo desvio padrão e coeficiente de variação.

\begin{tabular}{|c|c|c|c|c|}
\cline { 3 - 4 } & \multicolumn{2}{c|}{ Precisão } \\
\hline Amostra & $\begin{array}{c}\text { Concentração } \\
\text { em } \mu \mathrm{g} / \mathrm{mL}\end{array}$ & Média & $\begin{array}{c}\text { Desvio } \\
\text { Padrão }\end{array}$ & CV \\
& 8,202 & & & \\
Própolis & 8,185 & & & \\
(Minas Gerais) & 8,197 & $8,19 \mu \mathrm{g} / \mathrm{mL}$ & 0,0064 & $0,078 \%$ \\
& 8,190 & & & \\
& 8,194 & & & \\
& 8,200 & & & \\
\end{tabular}


A repetitividade das análises por CLAE da amostra de própolis foi demonstrada com o coeficiente de variação (desvio padrão relativo) de $0,00778 \%$. Para métodos que quantificam compostos em macro quantidades, recomenda-se um desvio padrão relativo ou coeficiente de variação de 1 a $3 \%$. Já para análises de traços e impurezas aceita-se uma variação de até 20\% (RIBANI et al., 2004).

\subsection{4- Exatidão}

A amostra de própolis bruta preparada contendo uma quantidade conhecida de artepillin-C determinou a exatidão do método através dos ensaios de recuperação. As taxas de recuperação obtidas podem ser visualizadas na Tabela 15 e seus valores variaram de 98 a $102 \%$

Os intervalos de recuperação aceitáveis para análise de resíduos estão entre 70 e $120 \%$, com uma variação de até $20 \%$. Dependendo da complexidade analítica e da amostra, este valor pode ser de 50 a $120 \%$, com uma variação de até $15 \%$ (RIBANI et al., 2004). Os resultados obtidos estão de acordo com a variação citada de até $15 \%$.

Tabela 15 - Taxa de Recuperação do padrão de Artepillin-C adicionado na amostra de Própolis

\begin{tabular}{c|c|c|c}
\hline Amostra & $\begin{array}{c}\text { Quantidade } \\
\text { Adicionada (\%) }\end{array}$ & $\begin{array}{c}\text { Taxa de Recuperação } \\
(\%)\end{array}$ & $\begin{array}{c}\text { Coeficiente de } \\
\text { variação (\%) }\end{array}$ \\
\hline \multirow{2}{*}{ Própolis } & 10 & 102 & 11 \\
(Minas Gerais) & 25 & 101 & 10 \\
& 50 & 98 & 7,5 \\
& 100 & 99 & 5,0 \\
\hline
\end{tabular}

$\left(^{*}\right)$ Os valores acima representam média de três repetições. 


\subsubsection{Determinação de artepillin-C por Cromatografia Líquida de Alta Eficiência}

As condições para a realização dos ensaios por cromatografia líquida de alta eficiência (CLAE) estão descritas no item 4.2 .2 e os resultados das 33 amostras estão apresentados na Tabela 16. 
Tabela 16 - Teor de Artepillin-C determinados por CLAE nas amostras de própolis.

\begin{tabular}{|c|c|c|c|c|c|}
\hline & $\begin{array}{l}\text { Identificação } \\
\text { das Amostras }\end{array}$ & Município & $\begin{array}{c}\text { Artepillin-C * } \\
(\%)\end{array}$ & $\begin{array}{l}\text { Desvio } \\
\text { Padrão }\end{array}$ & $\begin{array}{l}\text { CV } \\
(\%)\end{array}$ \\
\hline $\begin{array}{l}\frac{y}{d 0} \\
\frac{d}{0} \\
\frac{0}{2}\end{array}$ & $\begin{array}{l}1 \\
2 \\
3 \\
4 \\
5 \\
6 \\
7 \\
8\end{array}$ & $\begin{array}{c}\text { Mucuri } \\
\text { Irecê } \\
\text { Palmeiras } \\
\text { Lençóis } \\
\text { João Câmara } \\
\text { São Luiz } \\
\text { Santa Terezinha } \\
\text { João Pessoa }\end{array}$ & $\begin{array}{l}\text { N.D } \\
\text { N.D } \\
\text { N.D } \\
\text { N.D } \\
\text { N.D } \\
\text { N.D } \\
0,10 \\
0,25\end{array}$ & $\begin{array}{c}- \\
- \\
- \\
- \\
- \\
- \\
0,01 \\
0,02\end{array}$ & $\begin{array}{c}- \\
- \\
- \\
- \\
- \\
- \\
10,0 \\
7,60\end{array}$ \\
\hline $\begin{array}{l}\frac{0}{8} \\
\frac{d}{\partial} \\
\text { के }\end{array}$ & $\begin{array}{c}9 \\
10 \\
11 \\
12 \\
13 \\
14 \\
15 \\
16 \\
17 \\
18 \\
19 \\
20\end{array}$ & $\begin{array}{c}\text { Barbacena } \\
\text { Itabira } \\
\text { Lavras } \\
\text { Patrocínio } \\
\text { Juiz de Fora } \\
\text { Salesópolis } \\
\text { Barra do Chapéu } \\
\text { Paraíbuna } \\
\text { Cajamar } \\
\text { Pilar do Sul } \\
\text { Itaboraí } \\
\text { Paraíba do Sul }\end{array}$ & $\begin{array}{c}9,66 \\
5,68 \\
10,20 \\
8,93 \\
6,17 \\
4,53 \\
4,38 \\
5,75 \\
5,07 \\
11,04 \\
10,5 \\
6,65\end{array}$ & $\begin{array}{l}0,12 \\
0,31 \\
0,30 \\
0,25 \\
0,25 \\
0,34 \\
0,29 \\
0,23 \\
0,26 \\
0,15 \\
0,22 \\
0,24\end{array}$ & $\begin{array}{l}1,24 \\
5,46 \\
2,94 \\
2,80 \\
4,10 \\
7,50 \\
6,62 \\
4,00 \\
5,13 \\
1,36 \\
2,10 \\
3,61\end{array}$ \\
\hline$\overline{\bar{઼}}$ & $\begin{array}{l}21 \\
22 \\
23 \\
24 \\
25 \\
26 \\
27 \\
28 \\
29 \\
30\end{array}$ & $\begin{array}{c}\text { São José da Boa Vista } \\
\text { São Mateus do Sul } \\
\text { Wenceslau Brás } \\
\text { Ivaí } \\
\text { Içara } \\
\text { Anitápolis } \\
\text { Itajaí } \\
\text { Araranguá } \\
\text { Pelotas } \\
\text { Taquara }\end{array}$ & $\begin{array}{l}4,63 \\
3,10 \\
5,06 \\
2,63 \\
0,40 \\
0,30 \\
0,60 \\
0,22 \\
0,12 \\
0,18\end{array}$ & $\begin{array}{l}0,26 \\
0,23 \\
0,20 \\
0,20 \\
0,04 \\
0,02 \\
0,02 \\
0,02 \\
0,01 \\
0,01\end{array}$ & $\begin{array}{l}5,61 \\
7,42 \\
3,95 \\
7,60 \\
9,00 \\
5,67 \\
3,34 \\
6,82 \\
10,0 \\
5,56\end{array}$ \\
\hline 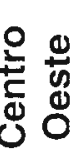 & $\begin{array}{l}31 \\
32 \\
33\end{array}$ & $\begin{array}{c}\text { Campo Grande } \\
\text { Mundo Novo } \\
\text { Angélica }\end{array}$ & $\begin{array}{l}7,10 \\
2,49 \\
1,23\end{array}$ & $\begin{array}{l}0,28 \\
0,18 \\
0,11\end{array}$ & $\begin{array}{l}3,94 \\
7,23 \\
8,94\end{array}$ \\
\hline
\end{tabular}

$\left({ }^{\star}\right)$ Os valores acima representam média de três determinações.

$\left.{ }^{* *}\right)$ N.D. = não detectado (abaixo do limite de detecção) 
Como pode ser observado na Tabela 16, existe uma grande variação no teor de Artepillin-C presente nas amostras de própolis, variando de 0,10 (Santa Terezinha - Nordeste) a 11,0\% (Pilar do Sul - São Paulo).

Existem vários trabalhos na literatura sobre a identificação e quantificação de artepillin em própolis. Aga et al (1994), isolaram e identificaram a estrutura do artepillin-C em amostras de própolis brasileira.

Park et al. (2004) avaliaram o teor de artepillin-C em amostras de própolis provenientes da região sudeste utilizando etanol para a obtenção do extrato. Os autores encontraram um valor médio de $3,8 \%$, sendo este inferior ao obtido neste trabalho.

Shimizu et al. (2004) estudaram amostras de própolis provenientes de Minas Gerais, realizando a extração do artepillin com etanol, encontrando um valor médio de $4,0 \%$, sendo este inferior ao valor reportado neste trabalho.

Funari (2005) identificou e analisou o teor Artepillin-C em amostras de própolis da Serra do Japi - SP utilizando metodologia de Alencar (2002). O autor confrontou extratos de própolis obtidos por maceração (em etanol) e por Soxlet (em metanol) obtendo valores de 3,40 e 5,48\%, respectivamente, sendo este último valor próximo ao obtido neste trabalho para as amostras de Paraíbuna e Cajamar (SP).

$\mathrm{Na}$ metodologia utilizada obteve-se um tempo de retenção menor (15 minutos) comparado aos obtidos pelos demais autores anteriormente citados (81 minutos). Esta diminuição do tempo de análise é vantajosa uma vez que no controle de qualidade para comercialização e exportação da própolis o custo da análise diminui assim como podem ser realizados mais análises com o mesmo tempo utilizando-se este método.

O Artepillin-C é um composto fenólico encontrado apenas em própolis 
brasileira, sendo um produto muito procurado por outros países tais como China e Japão. Avaliando os resultados da Tabela 16, pode-se observar que a própolis da região sudeste apresentou um alto teor de Artepillin-C comparado às outras regiões brasileiras provavelmente devido à vegetação presente na região.

O resultado da análise estatística está apresentado na Figura 37.

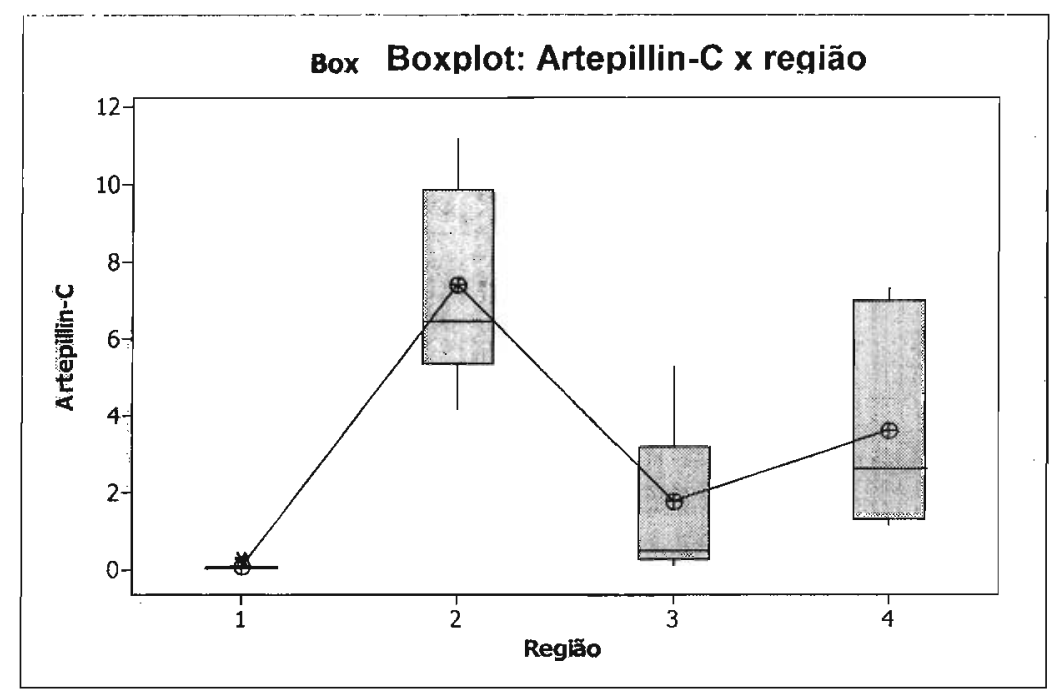

1: Nordeste

2: Sudeste

3: Sul

4: Centro-oeste

Figura 37: Gráfico da relação entre o teor de Artepillin-C de amostras de própolis em função das diversas regiões brasileiras.

Através do teste de Mood pode-se verificar que as quatro regiões não apresentaram a mediana dos niveis de artepillin- $C$ estatisticamente iguais, valor$p=0,000$. A região 2 apresentou mediana dos níveis de artepillin-C estatisticamente superior a região 3 (sul) e 4 (centro-oeste), enquanto que a região 4 (centro-oeste) apresentou mediana estatisticamente semelhante a região 3.

A Figura 32 mostra o perfil cromatográfico do padräo de Artepillin-C. 


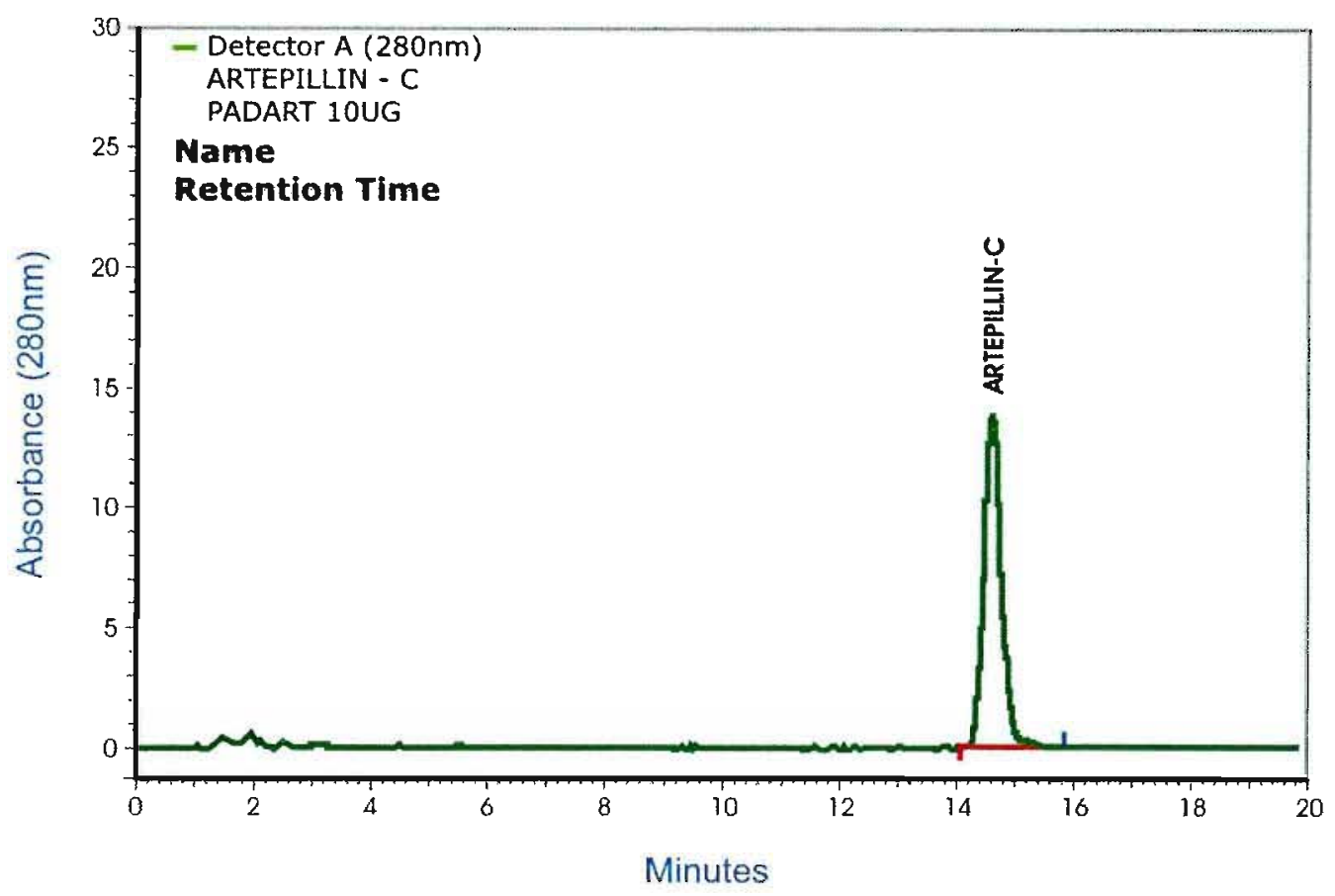

Figura 32 - Perfil cromatográfico do padrão de Artepillin-C. (Volume de padrão injetado: $20 \mu \mathrm{L}$; detector utilizado: ultravioleta $280 \mathrm{~nm}$; coluna: fase reversa C-18 ODS-A modelo Shimpack CLC-ODS $(\mathrm{m})$ de $150 \times 4,6 \mathrm{~mm}$ de dimensão com tamanho de partícula de $5 \mu \mathrm{m}$; fase móvel: acetoritrila / ácido fosfórico $0,1 \%(1: 1, \mathrm{v} / \mathrm{v})$; vazão: $1 \mathrm{~mL} / \mathrm{min}$.; temperatura: $25^{\circ} \mathrm{C}$ ).

As figuras 33 a 36 ilustram os cromatogramas característicos da análise de Artepillin-C de acordo com a região de origem. 


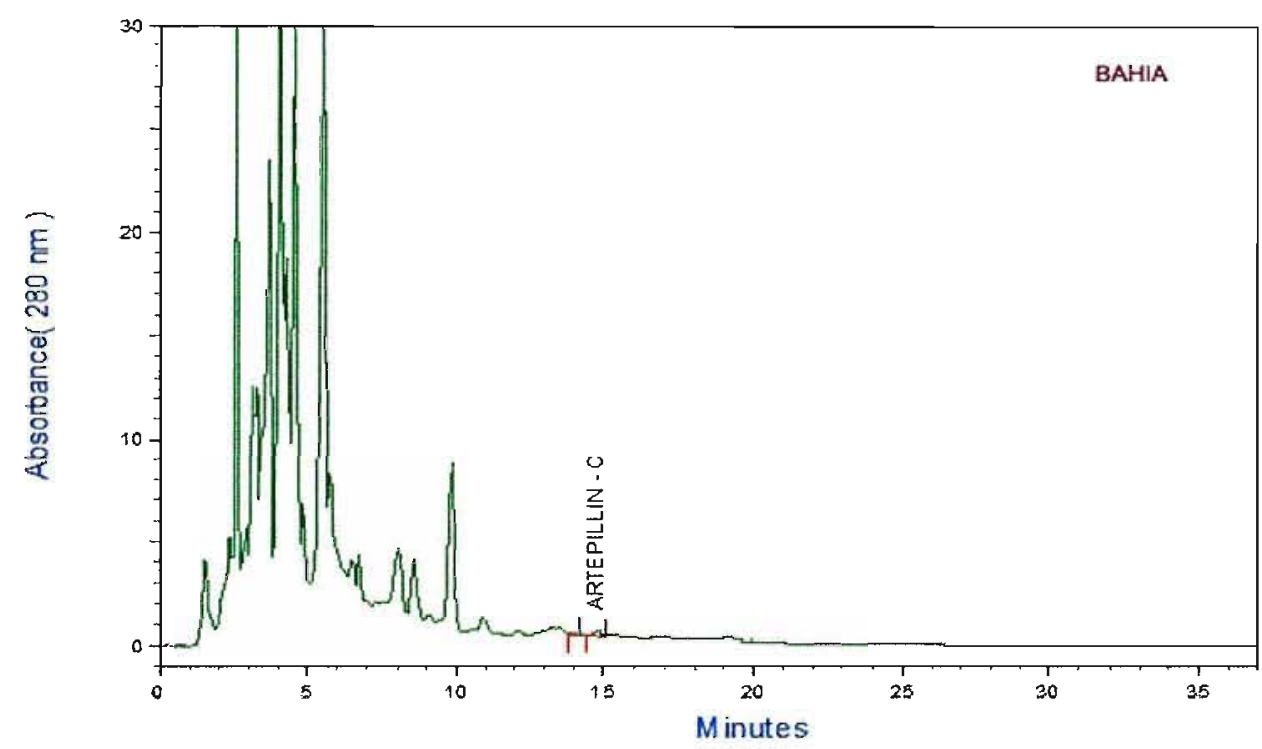

Figura 33 - Perfil cromatográfico da própolis - Região Nordeste.

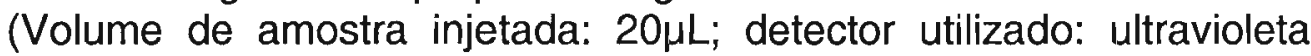
280nm; coluna: fase reversa C-18 ODS-A modelo Shimpack CLCODS (m) de $150 \times 4,6 \mathrm{~mm}$ de dimensão com tamanho de partícula de $5 \mu \mathrm{m}$; fase móvel: acetonitrila / ácido fosfórico 0,1\% (1:1, v/v); vazão: $1 \mathrm{~mL} /$ min.; temperatura: $25^{\circ} \mathrm{C}$ ).

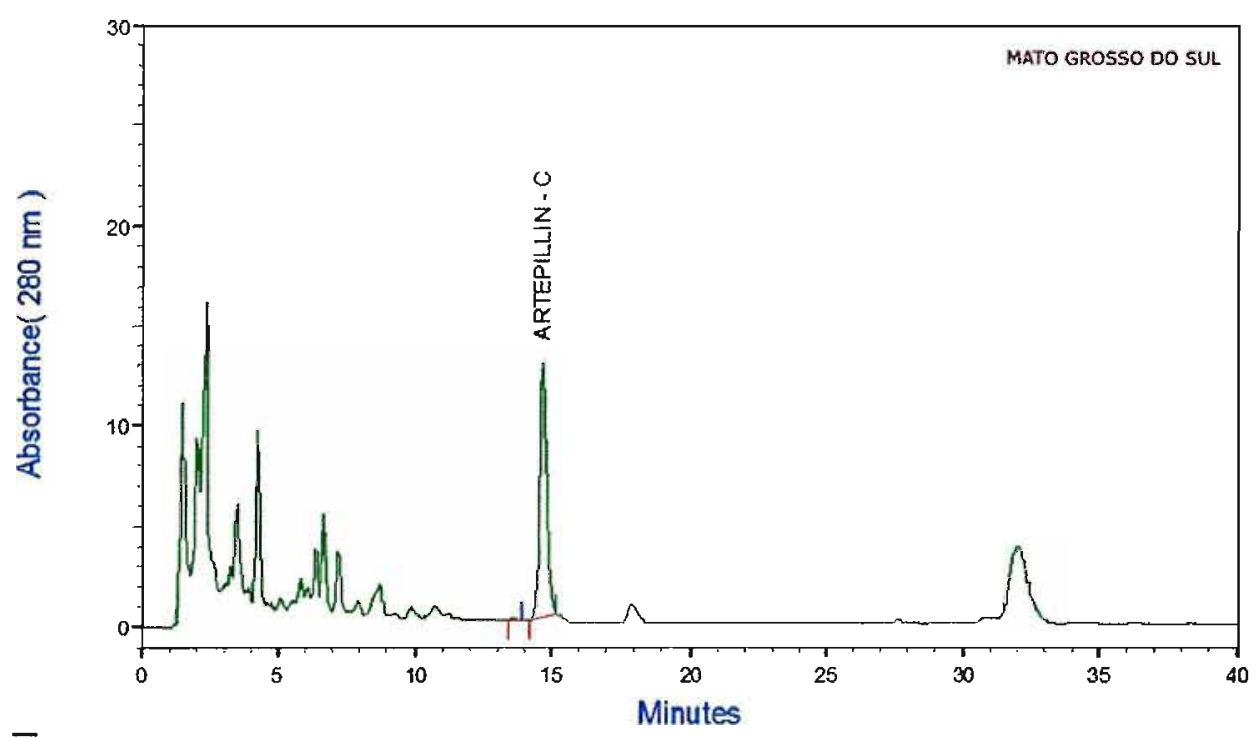

Figura 34 - Perfil cromatográfico da própolis- Região Centro-Oeste.

Volume de amostra injetada: 20 L ; detector utilizado: ultravioleta 280nm; coluna: fase reversa C-18 ODS-A modelo Shimpack CLC-ODS (m) de $150 \times 4,6 \mathrm{~mm}$ de dimensão com tamanho de partícula de 5um; fase móvel: acetonitrila / ácido fosfórico $0,1 \%(1: 1, \mathrm{v} / \mathrm{v})$; vazão: 1 $\mathrm{mL} /$ min.; temperatura: $25^{\circ} \mathrm{C}$ ). 

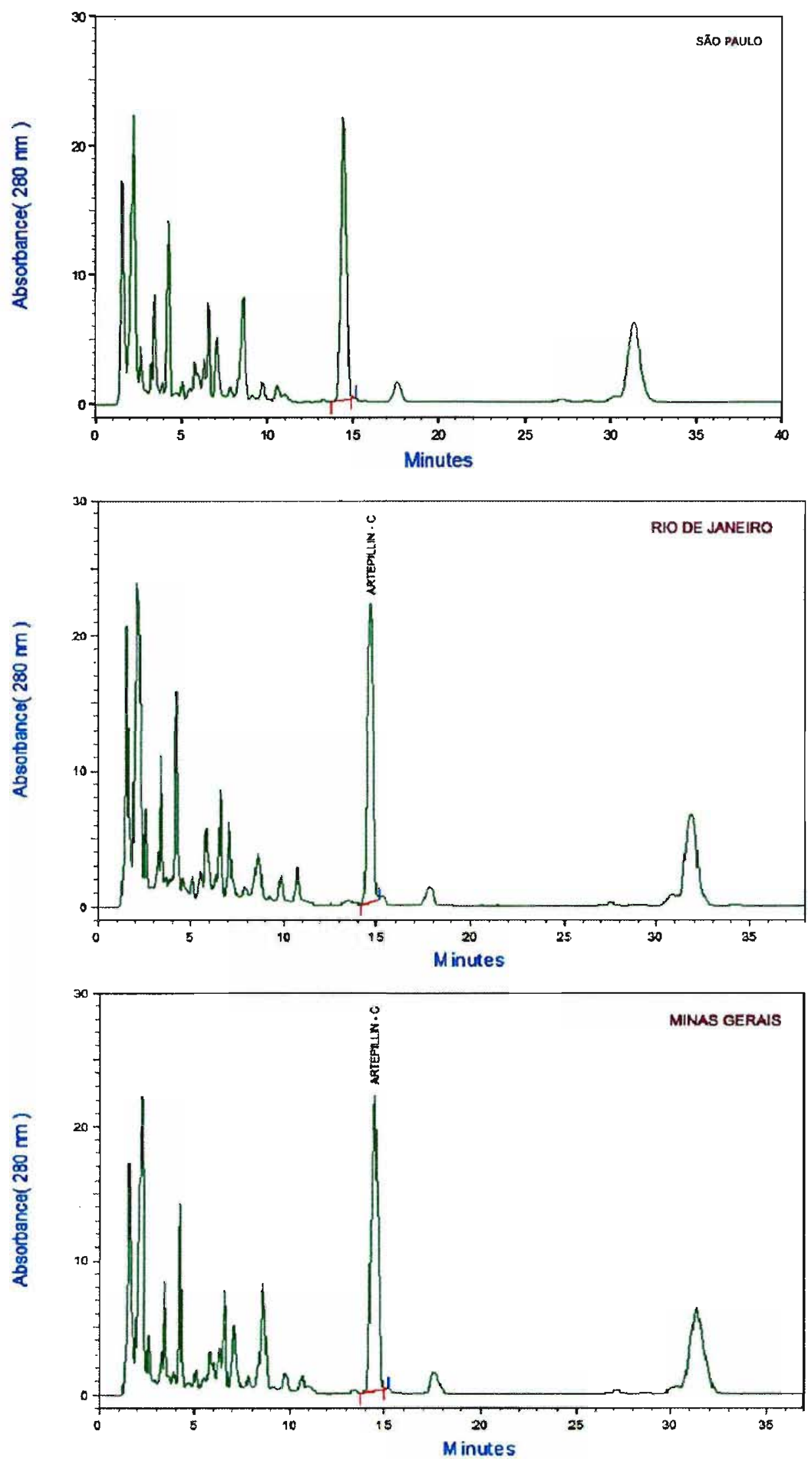

Figura 35 - Perfil cromatográfico da própolis - Região Sudeste.

(Volume de amostra injetada: $20 \mu \mathrm{L}$; detector utilizado: ultravioleta 280nm; coluna: fase reversa C-18 ODS-A modelo Shimpack CLCODS $(\mathrm{m})$ de $150 \times 4,6 \mathrm{~mm}$ de dimensão com tamanho de partícula de $5 \mu \mathrm{m}$; fase móvel: acetonitrila / ácido fosfórico $0,1 \%(1: 1, \mathrm{v} / \mathrm{v})$; vazão: $1 \mathrm{~mL} / \mathrm{min}$.; temperatura: $25^{\circ} \mathrm{C}$ ). 

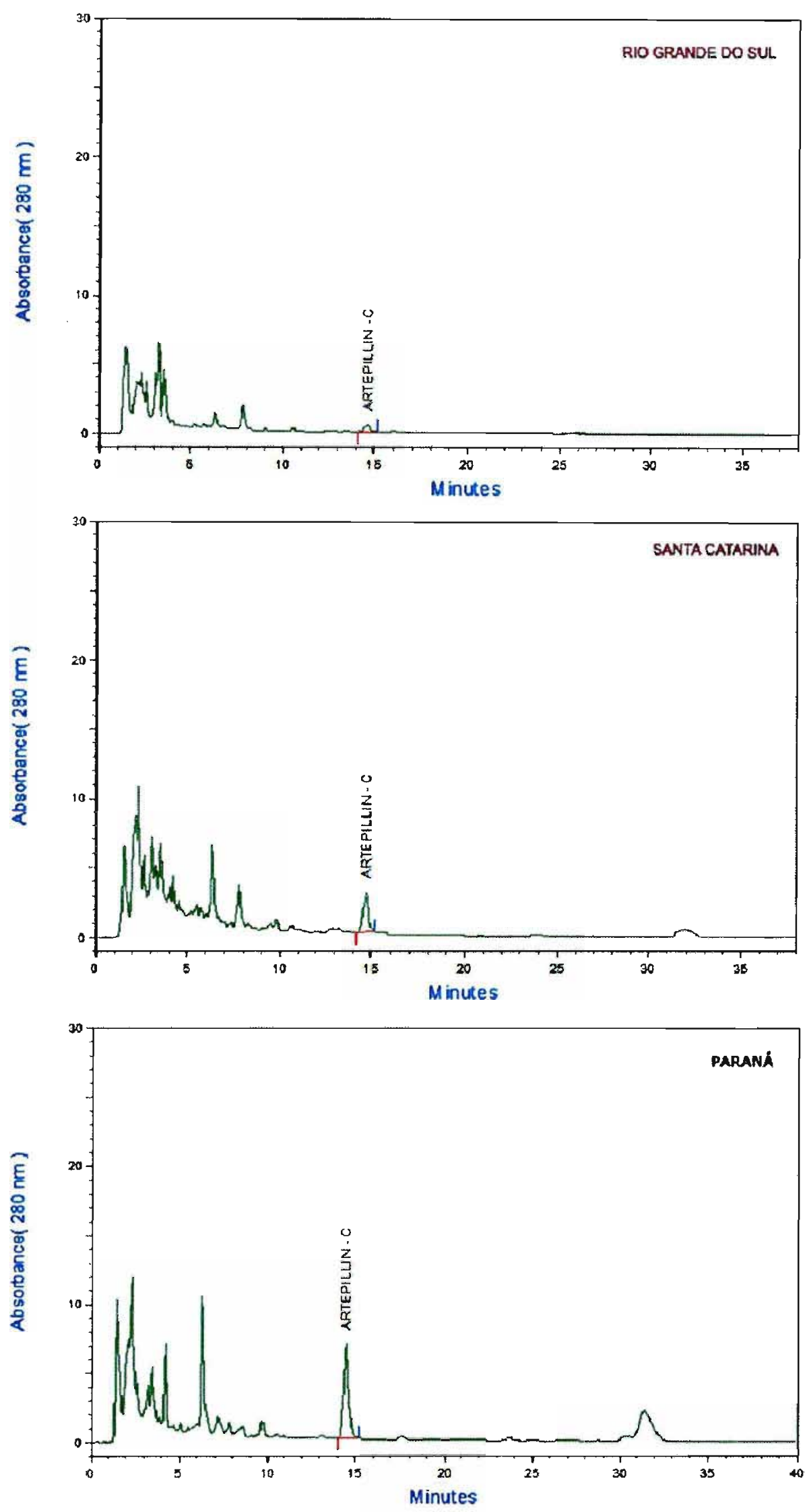

36 - Perfil cromatográfico da própolis - Região Sul.

Figura

(Volume de amostra injetada: $20 \mu \mathrm{L}$; detector utilizado: ultravioleta 280nm; coluna: fase reversa C-18 ODS-A modelo Shimpack CLCODS $(\mathrm{m})$ de $150 \times 4,6 \mathrm{~mm}$ de dimensão com tamanho de partícula de $5 \mu \mathrm{m}$; fase móvel: acetonitrila / ácido fosfórico $0,1 \%(1: 1, \mathrm{v} / \mathrm{v})$; vazão: $1 \mathrm{~mL} / \mathrm{min}$.; temperatura: $25^{\circ} \mathrm{C}$ ). 


\subsection{Análise estatística}

BIBLIOTECA

Faculdade de Ciências Farmacêulicas

- Universidade de Săo Paulo

O estudo estatístico realizado indicou que existe uma diferença significativa $(\alpha=5 \%)$ entre os parâmetros estudados em relação às diversas regiões brasileiras.

Constatou-se também uma forte correlação entre os seguintes parâmetros: cinzas e massa mecânica; compostos fenólicos e solúveis em etanol assim como compostos fenólicos e atividade antioxidante.

Dentre todos os parâmetros analisados, o índice de oxidação e a atividade antioxidante foram os que apresentaram maior e menor variabilidade entre as regiões, respectivamente. 


\section{CONCLUSÕES}

Considerando os resultados apresentados e discutidos a respeito da caracterização e controle de qualidade de própolis provenientes de diversas regiões do Brasil pode-se concluir que:

- A maioria das amostras analisadas apresentou resultados compativeis com os parâmetros de identidade e qualidade (PIC), estabelecidos pela legislação brasileira em vigor (Instrução Normativa n.3, de 19 de janeiro de 2001).

- A maioria das amostras apresentou alta atividade antioxidante apresentando variação estatística conforme a região estudada.

- Na análise polínica foi possível apenas identificar os grãos de pólen mais freqüentes uma vez que a metodologia utilizada é qualitativa.

- O método de análise do Artepillin $\mathrm{C}$ atendeu a todos os parâmetros preconizados para a validação do método cromatográfico (linearidade, precisão, exatidão, limite de detecção e limite de quantificação), podendo ser recomendado para análise de rotina em laboratórios de controle de qualidade.

- Dentre todas as regiões estudadas a região Sudeste foi a que apresentou maior teor de Artepillin C possuindo médias estatisticamente superiores as demais regiões.

- Através da análise estatística constatou-se uma forte correlação entre os seguintes parâmetros: cinzas e massa mecânica; compostos fenólicos e solúveis em etanol assim como compostos fenólicos e atividade antioxidante. Também foi constatada uma variação nos valores dos outros parâmetros analisados em função da procedência das amostras de própolis. 


\section{REFERÊNCIAS BIBLIOGRÁFICAS ${ }^{(*)}$}

AGA, H.; SHIBUYA, T.; SUGIMOTO, T.; KURIMOTO, M.; NAKAJIMA, S. Isolation and identification of antimicrobial compounds in Brazilian propolis. Biosci., Biotechnol., Biochem., Tokyo, v.58, n.5, p.945-946, 1994.

ALENCAR, S.M. Estudo fitoquímico da origem botânica da própolis e avaliação da composição química de mel de Apis mellifera africanizada de diferentes regióes do Brasil. Campinas, 2002. 120p. Tese de Doutorado - Faculdade de Engenharia de Alimentos - Universidade Estadual de Campinas.

ARVOUET-GRAND, A.; VENNAT, B.; GROSS, D.; POURRAT, A. Qualitative and quantitative analysis of flavonoids and identification of phenolic acids from propolis extract. J. Pharm. Belg., Bruxelles, v.50, n.5, p.438-444, 1995.

ASIS, M. Propóleo, el oro púrpura de las abejas. La Havana: Centro de Información y Documentación Agropecuária, 1989. 255p.

BANKOVA, V.S.; POPOV, S.; MAREKOV, N.L. High-performance liquid chromatographic analysis of flavonóides from propolis. J. Chromatogr., Amsterdam, v.242, n.2, p.135-143, 1982.

BANKOVA, V.S.; POPOV, S.; MAREKOV, N.L. A study on flavonoids of propolis. J. Nat. Prod., Columbus, v.46, n.4, p.471-474, 1983.

BANKOVA, V.S.; DYULGEROV, A.; POPOV, S.; MAREKOV, N.L. A CG/MS study of propolis phenolic constituents. Z. Naturforsch., Tuebingen, v.42, p.147-151, 1987.

* De acordo com a NBR6023/2000, preconizada pela Associação Brasileira de Normas Tecnicas (ABNT). As abreviaturas dos títulos dos periódicos seguem o Chemical Abstracts Service Source Index (CASSI), 2004. 
BANKOVA, V.S.; POPOV, S.; MAREKOV, N.L. Isopentenyl cinnamates from popular buds and propolis. Phytochemistry, Amsterdam, v.28, n.3, p.871-873, 1989.

BANKOVA, V.S.; DYULGEROV, A.; POPOV, S.; EVSTATIEVA, L.; KULEVA, L.; PUREB, O.; ZAMJANSAN, Z. Própolis produced in Bulgária and Mongólia: phenolic compounds and plant-origin. Apidologie, Les Ulis, v.23, n.1, p.79-85, 1992a.

BANKOVA, V.S.; CHRISTOV, R.; SOEV, G.; POPOV, S. Determination of phenolics from propolis by capillary gas chromatography. Apidologie, Les Ulis, v.607, p.150-153, 1992b.

BANKOVA, V.S.; CHRISTOV, R.; KUJUMGIEV, A.; MARCUCCI, M.C.; POPOV, S. Chemical composition and bacterial activity of Brazilian propolis. Z. Naturforsch., Tuebingen, v.50, p.167-172, 1995

BANKOVA, V.S.; BOUDOUROVA-KRASTEVA, G.; POPOV, S.; SFORCIN, J.M.; FUNARI, S.R.C. Seasonal variations of the chemical comoosition of Brazilian Própolis. Apidologie, Les Ulis, v.29, p.361-367, 1998.

BANKOVA, V.S.; BOUDOUROVA-KRASTEVA, G.; SFORCIN, J.M.; FRETE, X.; KUJUMGIEV, A.; MAIMONI-RODELLA, R.; POPOV, S.S. Phytochemical evidence for the plant origin of Brazilian propolis from São Paulo state. $\mathbf{Z}$. Naturforsch., C: J. Biosci., Tuebingen, v.54C, p.401-405, 1999.

BANKOVA, V.S.; CASTRO, S.L.; MARCUCCI, M.C. Própolis: recent advances in chemistry plant origin. Apidologie, Les Ulis, v.31, p.3-15, 2000a.

BANKOVA, V.S.; MARCUCCI, M.C. Standardization of própolis: present status and perspective. Bee World, Gerrards Cross, v.81, n.4, p.182-188, 2000. 
BANSKOTA, A.H.; TEZULA, Y.; PRASAIN, J.K.; MATSUSHIGE, K.; SAIKI, I.; KADOTA, S. Chemical constituents of Brazilian propolis and their activities. J. Nat. Prod., Columbus, v.61, p.896-900, 1998.

BASNET, P.; MATSUNO, M.; NEIDLEIN, R. Potent free radical scavenging activity of propel isolated from Brazilian propolis. Z. Naturforsch., C: J. Biosci., Tuebingen, v.52C, n.11/12, p.828-833, 1997.

BASTOS, E.M.A.F. Origem botânica e indicadores de qualidade da "própolis verde" produzida no Estado de Minas Gerais. Ribeirão Preto, 2001. 137p. Tese de Doutorado - Faculdade de Filosofia, Ciências e Letras de Ribeirão Preto - Universidade de São Paulo.

BARTH, O.M. Pollen analysis of Brazilian própolis. Grana, Oslo, v.37, p.97-101, 1998.

BARTH, O.M. Melissopalynology in Brazil: a review of pollen analysis of honeys, propolis and pollen loads of bees. Sci. Agric. v. 61, n.3, p. 342-350, 2004.

BARTH, O.M.; DUTRA, V.M.L.; JUSTO, R.L. Análise polínica de algumas amostras de própolis do Brasil Meridional. Ciênc. Rural, Santa Maria, v.29, n.4, p.663-667, 1999.

BARTH, O.M.; MARCUCCI, M.C; MATSUDA, A.H; ALMEIDA-MIURADIAN; L.B. Análise palinológica de própolis vermelha do Brasil. In: Jornada Fluminense de Botânica, 24, Encontro da Rede Fluminense de Herbários, 1; Nova Friburgo, 2005. Resumos. Nova Friburgo 2005. p. 34-35.

BOGDANOV, S. Determination of pinocembrin in honey using HPLC. J. Apic. Res., Cardiff, v.28, n.1, p.55-57, 1989. 
BOLETIN INFORMATIVO DA ASSOCIAÇAO JAPONESA DE SAÚDE E NUTRIÇAO. Kenkosyokuhin Kikaku Kijun no Koshi - Standard of Propolis as Food, n.6, p.8-10, 1994.

BONHEVI, S.J.; COLL, F.V.; JORDÁ, R.V. The composition, active components and bacteriostatic activity of propolis in dietetics. J. Am. Oil Chem. Soc., Champaign, v.71, n.5, p.529-532, 1994.

BRASIL. Instrução Normativa n.3, de 19 de janeiro de 2001. Regulamentos técnicos de identidade e qualidade de apitoxina, cera de abelha, geléia real, geléia real liofilizada, pólen apícola, própolis e extrato de própolis. Diário Oficial da União, Brasília, 23 de jan. de 2001. Seção 1, p.18-23.

BRENDOLAN, G. Validação de métodos cromatográficos. Pedreira: Expolabor e Isolabro Consultoria e Treinamento, 2000. 72p. [Apostila].

BRUSCHI, M.L. Desenvolvimento e caracterização de micropartículas obtidas a partir de extrato etanólico de própolis. Araraquara, 2002. 211 p. Dissertação de Mestrado - Faculdade De Farmácia - UNESP .

BURDOCK, G.A. Review of the biological properties and toxicity of bee própolis. Food Chem. Toxicol., Amsterdam, v.36, p.347-363, 1998.

CAMPOS, M.G.R.; SABATIER, S.; AMIOT, M.J.; AUBERT, S. Characterization of flavanoids in three hive products: bee pollen, propolis and honey. Planta Med., Stuttgart, v.56, p.580-581, 1990.

CARMO, L.H.A. Desenvolvimento e avaliação de formulações para uso externo contendo extrato de própolis. São Paulo, 1999. 154p. Dissertação de Mestrado - Faculdade de Ciências Farmacêutica - Universidade de São Paulo. 
CHASIN, A.A.M.; NASCIMENTO, E.S.; RIBEIRO-NETO, L.M.; SIQUEIRA, M.E.P.B.; ANDRAUS, M.H.; SALVADORI, M.C.; FERNÍCOLA, N.A.G.; GORNI, R.; SALCEDO, S. Validação de métodos em análises toxicológicas: uma abordagem geral. Rev. Bras. Toxicol., São Paulo, v.11, n.1, p.1-6, 1998.

CHRISTOV, R.; BANKOVA, V.S. Gas chrommatography analysis of underivatized phenolic constituints from propolis using an electron capture detector. $\mathbf{J}$. Chromatogr., Amsterdam, v.623, p.182-185, 1992.

COOK, N.C.; SAMMAN, S. Flavonoids-chemistry, metabolism, cardioprotective effects and dietary sources. J. Nutr. Biochem., Orlando, v.7, n.2, p.66-76, 1996.

CUNHA, I.B.S.; AWAYA, A.C.H.; CAETANO, F.M.; SHIMIZU, M.T.; MARCUCCI M.C.; DREZZA, T.F.; POVIA, G.S.; CARVALHO, P.O. Factors that influence the yield and composition of Brazilian propolis extracts. J. Braz. Chem. Soc., Campinas, v.15, n.6, p. 964-970, 2004.

D`ALBORE, G.R. L’origine geographique de la propolis. Apidologie, Les Ulis, v. 10, n.3, p. 241-267, 1979.

DEBIAGGI, M.; TATEO, F.; PAGANI, L.; LUINI, M.; ROMERO, E. Effects of propolis flavonóides on virus infectivity and replication. Microbiologica, Pavia, v.13, p.207-213, 1990.

DONADIEU, Y. La propolis: thérapeutique naturelle. Paris: Maloine, 1980. 45p.

DONDI, F.; BLO, G.; LODI, G.; BIGHI, C.; BENFENATI, L.; MONCALVO, E. Applications of high performance liquid chromatography in the analysis of cosmetics and toiletaries. Ann. Chim., Rome, v.74, p.117-127, 1984.

DOW, L. Spetrophotometric determination of quercetin. Anal. Chem., Columbus, v.31, n.7, p.1184-1187, 1959. 
FERRERES, F.; TÓMAS-BARBERÁN, F.; GIL, M.I.; TOMÁS-LORENTE, F. HPLC technique for flavonoid analysis in honey. J. Sci. Food Agric., Bognor Regis, v.56, p.49-56, 1991.

FÓRUM NACIONAL DE AGRICULTURA E APICULTURA. Padrões de identidade e qualidade para produtos apícolas. Belo Horizonte: FNA, 1997. 40p.

FRANCO, T.T.; KUREBAYASHI, A.K. Isolamento de princípios ativos da própolis por cromatografia em papel bidimensional e doseamento espectrofotométrico. Rev. Inst. Adolfo Lutz, São Paulo, v.46, n.1, p.81-86, 1986.

FRANCO, S.L. Própolis: otimização do processo extrativo: desenvolvimento de técnicas de controle de qualidade e produção de forma farmacêutica sólida. Araraquara, 2001. 157p. Tese de Doutorado - Faculdade de Farmácia Universidade Estadual de Paulista.

FRANCO, S.L.; BRUSCHI, M.L.; BUENO, J.H.F. Avaliação farmacognóstica da própolis da região do Paraná. Rev. Bras. Farmacogn., São Paulo, v.9/10, p.1$10,2000$.

FREE, J.B. A organização social das abelhas (APIS). São Paulo: EDUSP, EPU, 1980. 79p. (Coleção Temas de Biologia, v.13).

FRENKEL, K.; WEI, H.; BHIMANI, R.; YE, J.; ZADUNAISKY, J.; HUANG, M.T.; FERRARO, T.; CONNEY, A.H.; GRUNBERGER, D. Inhibition of tumor promotermediated processes in mouse skin and bovine lens by caffeic acid phenethyl ester. Cancer Res., Birmingham, v.53, n.5, p.1255-1261, 1993.

FUNARI, C.L. Análise de própolis da Serra do Japi, determinação de sua origem botânica e avaliação de sua contribuição em processos de cicatrização. São Paulo, 2005. 138p. Dissertação de Mestrado - Faculdade de Ciências Farmacêuticas - Universidade de São Paulo. 
GARCIA-AMOEDO, L.H.; ALMEIDA-MURADIAN, L.B. Comparação de metodologias para determinação de umidade em geléia real. Quím. Nova, São Paulo, v.25, n.4, p.676-679, 2002.

GARCIA-VIGUEIRA, C. Composition of propolis from different Spanish regions. Z. Naturforsch., C: J. Biosci., Tuebingen, v.47C, p.634-637, 1992.

GHISALBERTI, V.Q. Propolis: a review. Bee World, Gerrards Cross, v.60, n.2, p.5984, 1979.

GIL, M.I.; FERRETES, F.; ORTIZ, A.; SUBRA, E.; TÓMAS-BARBERÁN, F.A. Plant phenolic metabolites and floral origin of rosemary honey. J. Agric. Food Chem., Columbus, v.43, p.2833-2838, 1995.

GONZÁLES, E.; ORZALES, M.T. Estudios del propoleo: origin e importancia de los compuestos fenolicos en su composicion. Alimentaria, Madrid, v.283, p.103-107, 1997.

GONZÁLES, M; GUZMAN, B.; RUDYK, R.; ROMANO, E.; MOLINA, M.A.A. Spectrophotometric determination of phenolic compounds in propolis. Acta Farmaceutica Bonaerense, Catalunya, v.22, n.3, p. 243-248, 2003.

GREENAWAY, W.; SAYSBROOK, T.; WHATLEY, F.R. The composition and plant origins of propolis: a report of work at Oxford. Bee World, Gerrard Cross, v.71, n.3, p.107-118, 1990.

GREGÓRIO, L.E. Influência da sazonalidade na composição polínica, no perfil químico e na atividade antimicrobiana da própolis produzida em Cajuru-SP. Ribeirão Preto, 2003. 157p. Dissertação Mestrado - Faculdade de Ciências Farmacêuticas de Ribeirão Preto - Universidade de São Paulo. 
GRUNDBERGER, D.; BARNERJEE, R.; EISINGER, K.; OLTZ, E.M.; EFROS, L.; CALDWELL, M.; ESTEVZ, V.; NAKANISHI, K. Preferncial citotocity on tumor cell by caffeic acid phenethyl ester isolated from propolis. Experientia, Basel, v.44, p.230-232, 1988.

HAYASHI, K.; KOMURA, S.; ISAJI, N.; OHISHI, N.; YAGI, K. Isolation of antioxidative compounds from braziliam propolis: 3,4-Dihydroxy-5-prenylcinnamic acid, a novel potente oxidant. Chem. Pharm. Bull., Tokyo, v.47, n.11, p.1521$1524,1999$.

HEIMLER, D. High-performance thin-layer chromatography of selected flavonoid aglycones on ready-for-use layers of silanized silica gel. J. Chromatogr., Amsterdam, v.366, p.407-411, 1986.

HELFENBERG, K.D. The analyses of beeswax in propolis. Chem.-Ztg., Heidelberg, v.31, p.987-988, 1908.

$\mathrm{ICH}$ Q2a. Guideline: Quality. Text on validation of analytical procedure. Disponível em: http://www.ich.org. Acesso em: 29 jul. 2004.

ICH Q2b. Guideline: Quality. Text on validation of analytical prodecedure: methodology. Disponivel em: http://www.ich.org. Acesso em: 29 jul. 2004

IKENO, K.; IKENO, T.; MIYAZAWA, C. Effects of propolis on dental caries in rat. Caries Res., Basel, v.25, p.347-351, 1991.

IKEGAKI, M. Determinação de qualidade de própolis de Apis mellifera africanizada da região sul do Brasil: avaliação de algumas propriedades físicoquímicas e biológicas da própolis. Campinas, 2001. 274p. Tese de Doutorado Faculdade de Engenharia de Alimentos - Universidade Estadual de Campinas. 
INSTITUTO NACIONAL DE METROLOGIA, NORMALIZAÇAO E QUALIDADE INDUSTRIAL. Orientações sobre validação de métodos de ensaios químicos. São Paulo: INMETRO, 2003. 35p. (DOQ-CGCRE-008). Disponível em: http://www.inmetro.gov.br/kits/doqcgcre008r01.pdf. Acesso em: 10 jan. 2004.

INSTITUTO ADOLFO LUTZ. Normas analíticas do Instituto Adolfo Lutz. 3.ed. São Paulo: Instituto Adolfo Lutz, 1985. v.1, p.21-22.

ISLA, M.I.; MORENO, M.I.N.; SAMPIETRO, A.R.; VATTUONE, M.A. Antioxidant activity of Argentine propolis extract. J. Ethnopharmacol., Amsterdam, v.76, n.2, p.165-170, 2001.

ITO, J.; CHANG, F.R.; WANG, H.K.; PARK, Y.K.; IKEGAKI, M.; KILGORE, N.; LEE, K.H. Anti-AIDS agents. 48. Anti-HIV activity of moronic acid derivatives and the new mellifore-related triterpenoid isolated from Brazilian propolis. J. Nat. Prod., Columbus, v.64, p.1278-1281, 2001.

JURD, L.; GEISSMAN, T.A. Absorption spectra of metal complex of flavonoid compound. J. Org. Chem., Columbus, v.21, p.1395-1401, 1956.

KEDZIA, B.G.; IWASZKIWCZ, J. Pharmacological investigations of ethanolic extract of propolis. Phytoterapie, Heidelberg, v.6, p.7-10, 1990.

KIMOTO, T.; ARAI, S.; KOHGUCHI, M.; AGA, M.; NOMURA, Y.; MICALLEF, M.J.; KURIMOTO, M.; MITO, K. Apoptosis and suppression of tumor growth by artepillin-C extracted from Brazilian propolis. Cancer Detect. Prev., Amsterdam, v.22, n.6, p.506-515, 1998.

KOO, M.H. Estudo dos flavonóides da própolis de Apis mellifera africanizada provenientes de diversas regióes do Brasil. Campinas, 1996. 274p. Dissertação de Mestrado - Faculdade de Engenharia de Alimentos Universidade Estadual de Campinas. 
KOO, M.H.; PARK, Y.K. Investigation of flavonoid aglycones in propolis collected by two different varieties of bees in the same region. Biosci., Biotechnol., Biochem., Tokyo, v.61, n.2, p.367-369, 1997.

KRELL, R. Value-added products from beekeeping. Agric. Serv. Bull. (F.A.O.), Rome, v.124, p.87-113, 1996.

KROL, W.; SCHELLER, S.; SHANI, J.; PIETTSZ, G.; CZUBA, Z. Synergistic effect of ethanolic extract of propolis and antibiotics on the growth of Staphylococcus aureus. Arzneim. Forsch., Aulendorf, v.48, n.3, p.607-609, 1993.

KROL, W.; SCHELLER, S.; CZUBA, Z.; MATSUNO, T.; ZYDOWICZ, G.; SHANI, J.; MOS, M. Inhibition of neutrophilis chemiluminescense by ethanol extract of propolis (EEP) and its phenolic components. J. Ethnopharmacol., Amsterdam, v.55, p.19-25, 1996.

KUJUMGIEV, A.; TSVETKOVA, I.; SERKEDJIEVA, Y.; BANKOVA, V.; CHRISTOV, R.; POPOV, S. Antibacterial, antifungical and antiviral activity of própolis of different geographic origin. J. Ethnopharmacol., Amsterdam, v.64, n.3, p.235$240,1999$.

KUMAZAWA, S.; YONEDA, M.; SHIBATA, I.; KANAEDA, J.; HAMASAKA, T.; NAKAYAMA, T. Direct eidence for the plant origin of Brazilian propolis by the observation of honeybee behavior and phytochemical analysis. Chem. Pharm. Bull., Tokyo, v.51, n.6, p.740-742, 2003.

LEITE, F. Validação em análise química. Campinas: Átomo, 1998. 224p.

MACIEJEWICZ, W.; DANIEWSKI, M.; BAL, K.; MARKOWSKI, W. GC-MS identification of the flavonoid aglycones isolated from propolis. Chromatographia, Wiesbaden, v.53, n.5/6, p.343-346, 2001. 
MARCUCCI, M.C. Propolis: chemical composition, biological properties and therapeutic activity. Apidologie, Les Ulis, v.26, p.83-99, 1995.

MARCUCCI, M.C. Propriedades biológicas e terapêuticas dos constituintes químicos da própolis. Quím. Nova, São Paulo, v.19, n.5, p.529-526, 1996.

MARCUCCI, M.C. Apostila de análise de própolis. Pindamonhangaba: Instituto de Zootecnia, Centro de Apicultura Tropical, 1998, 70p.

MARCUCCI, M.C. Controle de qualidade de própolis. São Paulo, 1998. Disponível em: http://www.apacame.org.br/mensagemdoce/48/artigo2.htm. Acesso em: 09 set. 2003.

MARCUCCI, M.C.; RODRIGUEZ, J.; FERRERES, F.; BANKOVA, V.; GROTO, R.; POPOV, S. Chemical composition of Brazilian própolis from São Paulo staste. Z. Naturfordch., C: J. Biosci., Tuebigen, v.53C, p.117-119, 1998.

MARCUCCI, M.C.; BANKOVA, V. Chemical composition, plant origin and biological activity of Brazilian propolis. Phytochemistry, Amsterdam, v.2, p.115-123, 1999.

MARKHAM, K.R. Ultraviolet and visible absorption spectroscopy. In: HARBORNE, J.B.; MABRY, T.J.; MABRY, H. The flavonoids. New York, Academic Press, 1975. p.47-61.

MARKHAM, K.R.; MITCHELL, K.A.; WILKINS, A.L.; DALDY, J.A.; LU, Y. HPLC and GC-MS identification of the major organic constituents in New Zealand propolis. Phytochemistry, New York, v.42, n.1, p. 205-211, 1996.

MARKHAM, K.R.; MITCHELL, K.A.; WILKINS, A.L.; DALDY, J.A.; LU, Y.R. HPLC and GC-MS identification of the major organic constituents in New Zealand propolis. Phytochemistry, Amsterdam, v.42, n.1, p.205-211, 1996. 
MARKHAM, K.R. Chemical methods used in flavonoid structure elucidation. In: . Techniques of flavonoid identification. London, New York: Academic Press, 1982. cap.5, p.62-70. (Biological techniques series).

MARTOS, I.; COSSENTINI, M.; FERRERES, F.; TÓMAS-BARBERÁN, F.A. Flavonoid composition of Tunisian honey and propolis. J. Agric. Food Chem., Columbus, v.45, p.2826-2829, 1997.

MATSUDA, A.H. Aplicação da técnica de irradiação gama para preservação de própolis. São Paulo, 2002. 72p. Dissertação de Mestrado - Instituto de Pesquisa Energéticas e Nucleares.

MATSUDA, S.H. Propolis - health care food. Foods Food Ingredients J. Jpn., Toyonaka, v.160, p.64-73, 1994.

MATSUNO, T.; JUNG, S.K.; MATSUMOTO, Y.; SAITO, M.; MORIKAWA, J. Preferencial cytotoxicity to tumor cells of 3,5-Diprenyl-4-Hydroxycinnamic acid (Artepillin-C) isolated from propolis. Anticancer Res., Attiki, v.17, p.3565-3568, 1997.

MERCK Index: an encyclopedia of chemicals, drugs, and biologicals. 12.ed. Whitehouse Station: Merck, 1996. p.1741.

MIDORIKAWA, K.; BANSKOTA, A.H.; TEZUKA, Y.; MATSUSHIGE, K.; MESSAGE, D.; HUERTAS, A.A.G.; KADOTA, S. Buds of Baccharis dracunculifolia: potent source of biologically active caffeoylquinic acids and labdane-type diterpenes of Brazilian propolis. Wakan lyakugaku Zasshi, Toyama, v.20, n.5, p.187-194, 2003.

MORI, A.L.P. Própolis - Identificação de flavonóides e ácidos aromáticos em tintura: estimativa de FPS de extrato mole em base cosmética. São Paulo, 1997. 114p. Dissertação de Mestrado - Faculdade de Ciências Farmacêuticas Universidade de São Paulo. 
NAGAY, M.; GRANCAI, D. Colorimetric determination of flavanones in propolis. Pharmazie, Eschborn, v.51, n.2, p.100-101, 1996.

NAKANISHI, I.; UTO, Y.; OHKUBO, K.; MIYAZAKI, K.; YAKUMARU, H.; URANO, S.; OKUDA, H.; UEDA, J.I; OZAWA, T.; FUKUHARA, K.; FUKUZUMI, S.; NAGASAWA, J.; HORI, H.; IKOTA, N. Efficient radical scavenging ability os artepillin-C, a major component of Brazilian propolis, and the mecanism. Org. Biomol. Chem., Letchworth, v.1, n.9, p.1452-1454, 2003.

NEGRI, G.; MARCUCCI, M.C.; SALATINO, A.; SALATINO, M.L.F. Hydrocarbons and monoesters of propolis wax from Brasil. Apidologie, Les Ulis, v.29, p.305$314,1998$.

NEGRI, G.; SALATINO, M.L.F.; SALATINO, A. Unusual chemical composition of a sample of Brazilian propolis, as assessed by analysis of a chloroform extract. J. Apic. Res., Cardiff, v.42, n.4, p.53-56, 2003.

NIKOLOVSKA-COLESKA, Z.; KLISAROVA, L.; SUTURKOVA, L.; DOREVSKI, K. First and second derivative spectrophotometric determination of flavonoids and quercetin. Anal. Lett., Philadelphia, v.29, n.1, p.97-115, 1996.

JAUBERT, G.F. Origin of the color of beeswax and the composition of propolis. C. R. Hebd. Seances Acad. Sci., Paris, v.184, p.1134-1136, 1927.

PALMA, M.S.; MALASPINA, O. El propóleo. Apitec, Ciudad de Mexico, n.17, p.6-10, 2000.

PAPAY, V.; TÓTH, L.; SOLTÉSZ, M.; NAGY, É.; LITKEI, G. Isolated compounds from Hugarian propolis an Populi gemma. In: FARKAS, L.; GÁRBOR, N.; KÁLLAY, F. Flavonoids and bioflavonoids. Amsterdam: Elsevier, 1985. p.233230. 
PARK, Y.K.; KOO, M.H.; SATO, H.H.; CONTADO, J.L. Estudos de alguns componentes da própolis coletada por Apis mellifera no Brasil. Arq. Biol. Tecnol., Curitiba, v.38, n.4, p.1253-1259, 1995.

PARK, Y.K.; KOO, M.H.; IKEGAKI, M.; CONTADO, J.L. Comparasion of the flavonoid aglycone contents of Apis mellifera propolis from various Brazilian regions. Arq. Biol. Tecnol., Curitiba, v.40, n.1, p.97-106, 1997.

PARK, Y.K.; IKEGAKI, M. Preparation of water and ethanolic of propolis and evaluation of preparations. Biosci., Biotechnol., Biochem., Tokyo, v.11, p.22302232, 1998.

PARK, Y.K.; KOO, M.H.; IKEGAKI, M.; CURY, J.A.; ROSALEN, P.L. Effects of propolis os Streptococcus mutans, Actinomyces naeslundii and Staphylococcus aureus. Rev. Microbiol., São Paulo, v.29, n.2, p.143-148, 1998a.

PARK, Y.K.; KOO, M.H.; ABREU, J.A.S.; IKEGAKI, M.; CURY, J.A.; ROSALEN, P.L. Antimicrobial activity of propolis on oral microorganisms. Curr. Microbiol., Secaucus, v.36, n.1, p.24-28, 1998 b.

PARK, Y.K.; IKEGAKI, M.; ALENCAR, S.M.; MOURA, F.F. Evaluation of Brazilian propolis by both physicochemical methods and biological activity. HoneyBee Sci., Tokyo, v.21, n.2, p.85-90, 2000.

PARK, Y.K.; ALENCAR, S.M.; AGUIAR, C.L. Botanical origin and chemical composition of Brazilian propolis. J. Agric. Food Chem., Columbus, v.50, n.9, p.2502-2506, 2002.

PARK, Y.K.; PAREDES-GUZMAN, J.F.; AGUIAR, C.L.; ALENCAR, S.M.; FUJIWARA, F.Y. Chemical constituents in Baccharis dracunculifolia as the main botanical origin of Southeastern Brazilian propolis. J. Agric. Food Chem., Columbus, v.52, n.5, p.1100-1103, 2004. 
PEPEJNJAK, S.; JALSENJAK, I.; MAYSINGER, D. Flavonoid content in propolis extract and growth inhibition of Bacillus subtilis. Pharmazie, Eschborn, v.40, n.2, p.122-123, 1985.

PEREIRA, A.S.; PINTO, A.C.; CARDOSO, J.N.; NETO, F.R.D.; RAMOS, H.F.D.; DELLAMORA-ORTIZ, G.M.; SANTOS, E.P. Application of high temperature high resolution gas chromatography to crude extracts of propolis. J. High Resolut. Chromatogr., Heidelberg, v.21, n.7, p.396-400, 1998.

PIETTA, P.G.; GARDANA, C.; PIETTA, A.M. Analytical methods for quality control of propolis. Fitoterapia, Milano, v.1, p.7-20, 2002.

RIBANI, M.; BOTTOLI, C.B.G.; COLLINS, C.H.; JARDIN, I.C.S.F; MELO, L.F.C. Validação em métodos cromatográficos e eletroforéticos. Quím. Nova, São Paulo, v.27, n.5, p.771-780, 2004.

SABATIER, S.; AMIOT, M.J.; TACCHINI, M.; AUBERT, S. Identification of flavonoides in sunflower honey. J. Food Sci., Chicago, v.57, n.3, p.773-774, 1992.

SCHELLER, S.; STOJKO, A.; SZWARNOWIECKA, I.; TUSTANOWSKI, J.; OBUSZKO, Z. Biological properties and clinical application of propolis. VI. Investigation of the influence of ethanol extract of propolis (EEP) on cartilaginous tissue regeneration. Arzneim. Forsch., Aulendorf, v.27, n.6, p.2138-2140, 1977.

SCHELLER, S.; SZAFLARSKI, J.; TUSTANOWSKI, J.; NOLEWAJKA, E.; STOJKO, A. Biological properties and clinical application of Propolis. Arzneim. Forsch., Aulendorf, v.27, n.4, p.889-890, 1977a.

SHIMIZU, K.; ASHIDA, H., MATSUURA, Y.; KANAZAWA, K. Antioxidative bioavailability of Artepillin C in Brazilian propolis. Arch. Biochem. Biophys., New York, v.424, n.2, p.181-188, 2004. 
SIESS, M.H.; Le BON, A.M.; CANIVENC-LAVIER, M.C.; AMIOT, M.J.; SABATIER, S.; AUBERT, S.; SUSCHETET, M. Flavonids of honey and propolis: characterization and effects on hepatic drug-metabolizing enzymes and benzo $(\alpha)$ pryrene-DNA binding in rats. J. Agric. Food Chem., Columbus, v.44, p.2297-2301, 1996.

SOLER, C.; GIL, M.I.; GARCIAA-VIGUEIRA, C.; TOMÁS-BARBERÁN, F.A. Flavonoid patterns of French honey with different floral origin. Apidologie, Les Ulis, v.26, p.53-60, 1995.

SOUZA, K.C.B.; SCHAPOVAL, E.E.S.; BASSANI, V.L. LC determination of flavonoids: separation of quercetin, luteolin and 3-O-metoxi quercetin in Achyrocline satureioides preparations. J. Pharm. Biomed. Anal., Amsterdam, v.28, n.3-4, p.771-777, 2002.

SZEWCZK, E.H.; GODOY, G.F. Um estudo científico sobre a própolis. Apic. Brasil, São Paulo, v.1, n.3, p.28, 1987.

SWARTZ, M.E.; KRULL, I.S. Validação de métodos cromatográficos. Pharm. Technol., Ed. Bras., São Paulo, v.2, n.3, p.12-20, 1998.

TEIXEIRA, E.W.; MESSAGE, D.; MEIRA, R.M.S.A;. SALATINO, A. Indicadores da origem botânica da própolis: importância e perspectiva. B. Indústr. Anim., N. Odessa, v.60, n.1, p. 83-106, 2003.

THOMAS, M.J. The role of free radicals and antioxidants. Nutrition, New York, v. 16, n. $7 / 8$, p. $8-16,2000$.

TOMÁS-BARBERÁN, F.A.; GARCÍA-VIGUERA, C.; VIT-OLIVIER, P.; FERRERES, F.; TOMÁS-LORENTE, F. Phytochemical evidence for the botanical origin of tropical propolis from Venezuela. Phytochemistry, Amsterdam, v.34, n.1, p.191196, 1993. 
UTO, Y.; HIRATA, A.; FUJITA, T.; TAKUBO, S.; NAGASAWA, H.; HORI, H. First total synthesis of Artepillin $C$ established by, o, ó-diprenylation of p-halophenols in water. J. Org. Chem., Columbus, v.67, n.7, p.2355-2357, 2002.

VALCIC, S.; MONTENEGRO, G.; MUJICA, A.M.; AVILA, G.; FRANZBLAU, S.; SINGH, M.P.; MAIESE, W.M.; TIMMERMANN, B.N. Phytochemical, morphological and biological investigation of propolis from central Chile. $\mathbf{Z}$. Naturforsch., C: J. Biosci., Tuebingen, v.54C, n.5/6, p.406-416, 1999.

VANHAELEN, M.; VANHAELEN-FASTRÉ, R. Propolis. 1. Origine, micrographie, compositios chimique et activité thérapeutique. J. Pharm. Belg., Bruxelles, v.34, n.5, p.253-259, 1979.

VENNAT, B.; ARVOUET-GRAND, A.; GROSS, D.; POURRAT, A. Qualitative and quantitative analysis of flavonoides and identification of phenolic acids from a propolis extract. J. Pharm. Belg., Bruxelles, v.50, n.5, p.438-444, 1995.

VIAL, J.; JARDY, A. Experimental comparison of the different aproaches to estimate LOD and LOQ of an HPLC methods. Anal. Chem., Columbus, v.71, p.2672$2677,1999$.

VYNOGRAD, N.; VYNOGRAD, I.; SOSNOWSKI, Z. A comparative multicenter study of the efficacy of propolis, acyclovir and placebo in the treatment of genital herpes (HSP). Phytomedicine, Jena, v.7, p.1-6, 2000.

WALKER, P.; CRANE, E. Constituents of propolis. Apidologie, Les Ulis, v.18, p.327-334, 1987.

WARAKOMSKA, Z.; MACIEJEWICZ, W. Microscopic analysis of propolis from polish regions. Apidologie, Les Ulis, v.23, p.277-283, 1992.

WATERMAN, P.G., MOLE, S. Analysis of phenolic plant metabolites. Oxford: Blackwell Scientific Publictions, 1994. 238p 
WINSTSON, M.L. The biology of the honey bee. London: Harvard University Press, 1987. 281p.

WOISKY, R.G.; GIESBRECHT, A.M.; SALATINO, A. A atividade antibacteriana de uma formulação preparada a partir de própolis de Apis mellifera L. Rev. Farm. Bioquim. Univ. São Paulo, São Paulo, v.30, n.1, p.19-21, 1994.

WOISKY, R.G. Métodos químicos para controle de amostras de própolis. São Paulo, 1996. 74p. Dissertação de Mestrado - Faculdade de Ciências Farmacêuticas - Universidade de São Paulo.

WOISKY, R.G.; SALATINO, A. Analysis of propolis: some parameters and chemical quality control. J. Apic. Res., Cardiff, v.37, n.2, p.99-105, 1998.

WOOD, R. How validate analytical methods. TrAC, Trends Anal. Chem., Amsterdam, v.18, n.9, p.624-632, 1999.

ZUANAZZI, J.A.S. Flavonóides. In: SIMÕES, C.M.O.; SHENKEL, E.P.; GOSMANN, G. MELLO, J.C.P.; MENTZ, L.A.; PETROVICK, P.R., orgs. Farmacognosia: da planta ao medicamento. Porto Alegre: UFRG; Florianópolis: UFSC, 1999. cap.23, p.489-516. 